\title{
DOSSIÊ DO SEMINÁRIO \\ (RE)DISCUSSÃO SOBRE AS GRANDES ÁREAS DO \\ CONHECIMENTO \\ IEA-USP / NAP-CIPEM
}

\section{Resumo}

Ao longo de 2018, na Sala Alfredo Bosi do Instituto de Estudos Avançados da Universidade de São Paulo (IEA-USP), foram realizados três encontros, coordenados pelo Prof. Dr. Rubens Russomanno Ricciardi, que trataram de diversas questões a respeito da organização das grandes áreas do conhecimento, da cientometria e das métricas redutivas de avaliação da pesquisa acadêmica, dentre outros assuntos. $\bigcirc$ primeiro encontro procurou levantar os problemas de cada área e os conflitos provocados pelas avaliações e pela fragmentação do conhecimento em setores isolados, cujo reflexo sejam unidades universitárias menos unidas, mais competitivas e menos éticas, mediadas pelo discurso estéril do produtivismo nas ciências, nas artes e na filosofia. segundo encontro, a partir das discussões anteriores, colocou em cena o problema da divisão das áreas do conhecimento e do não reconhecimento de suas especificidades, bem como de outras maneiras de publicar um estudo, incluindo as pesquisas nas artes, para além do paper. $O$ terceiro encontro abordou, dentre outros, o problema de as linhas de pesquisa engessarem o pesquisador e de as métricas arbitrárias ferirem a liberdade da pesquisa. Em todos os momentos, sublinhou-se a importância do Manifesto de Leiden, que se coloca contra os critérios redutivos de avaliação acadêmica, bem como os rankings internacionais, em geral mais preocupados com questões não acadêmicas. Sob esse amplo escopo, chamou-se atenção para o fato de que as pesquisas nas artes são reduzidas, desincentivadas ou esquecidas, em função de preconceitos que impedem novas configurações de pesquisa, sob tratamento diferenciado e inventivo. Afinal, se o conhecimento é variado e, ao mesmo tempo, não fragmentado, por que a produção de pesquisa deve se pautar por modelos reduzidos e estanques, que privilegiam uma área em detrimento de outra? Em suma, tratando desses problemas que assombram a liberdade de pesquisa, dentre outras questões, este dossie apresenta ao leitor as falas de professores e convidados que participaram dos debates sobre os problemas da avaliação do conhecimento por meio de métricas redutivas, da fragmentação do saber em áreas isoladas que não mais conversam entre si e da exclusão de outras formas de expressão científica, além do paper. 
Palavras-chave: Áreas do conhecimento; Cientometria; Paper; Pesquisa artística.

\begin{abstract}
In 2018, the Sala Alfredo Bosi, in the Instituto de Estudos Avançados da Universidade de São Paulo (IEA-USP), hosted three meetings, coordinated by Prof. Dr. Rubens Russomanno Ricciardi. The encounters dealt with various issues regarding the organization of the great areas of knowledge, scientometrics, and the reductive metrics for the evaluation of academic research, among other subjects. The first meeting sought to raise the major problems in each area and the conflicts caused by the evaluations and by the fragmentation of the knowledge in isolated sectors, which reflect less united, more competitive, and less ethical units of the university. Plus, one highlighted the sterile discourse of productivity in science, arts, and philosophy. The second meeting, based on the previous discussions, examined the problem of the division of the areas of the knowledge and the non-recognition of their specificities, as well as other ways of publishing a study, including the research in the arts, besides the academic paper. The third meeting looked at the problem of the rigidness of the research's lines, and the arbitrary metrics, which reduces the freedom of the researcher. In all moments, the importance of the Leiden Manifesto was stressed, which stands against the reductive criteria of academic evaluation, as well as the international rankings, in general, more concerned with non-academic issues. Under this broad scope, one drew attention to the fact that the research in the arts is reduced, discouraged or forgotten, due to prejudices that prevent new research configurations, under differentiated and inventive treatment. After all, if knowledge is varied and, at the same time, not fragmented, why should research production be guided by reduced and tight models, which privilege one area over another? In short, dealing with these problems that haunt the freedom of research, among other issues, this dossier presents to the reader the speeches of professors and guests who participated in discussions on the problems of the evaluation of the knowledge through reductive metrics, on the fragmentation of the knowledge in isolated areas that no longer talk to each other, and on the exclusion of other forms of scientific expression, besides the academic paper.
\end{abstract}

Keywords: Areas of the Knowledge; Scientometrics; Paper; Research in the arts. 
Seminário em três encontros idealizado e coordenado pelo Prof. Dr. Rubens Russomanno Ricciardi

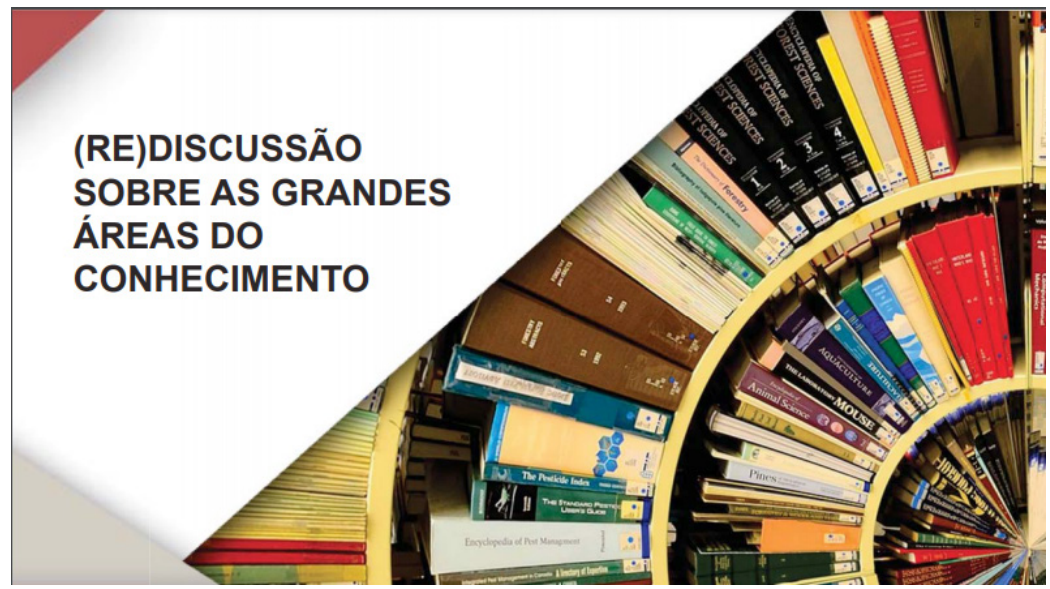

Coordenação: Prof. Dr. Rubens Russomanno Ricciardi (DM-FFCLRP-USP)

Realização: Instituto de Estudos Avançados da Universidade de São Paulo (IEA-USP) \& Núcleo de Pesquisa em Ciências da Performance do Departamento de Música da Faculdade de Filosofia, Ciências e Letras de Ribeirão Preto da Universidade de São Paulo (NAP-CIPEM)

Sala Alfredo Bosi do IEA-USP, em São Paulo

I Seminário: 13 de abril de 2018

II Seminário: 29 de junho de 2018 III Seminário: 04 de outubro de 2018

Transcrição: Daniel Portioli Rolnik (Técnico para Assuntos Administrativos, FFCLRP-USP)

Organização e revisão: Prof. Dr. Paulo Eduardo de Barros Veiga (professor colaborador e pós-doutorando, com bolsa FAPESP, do DM-FFCLRP-USP) 


\section{SIGLAS INSTITUCIONAIS}

CAPES - Coordenação de Aperfeiçoamento de Pessoal de Nivel Superior do Ministério da Educação

FAPERJ - Fundação de Amparo à Pesquisa do Estado do Rio de Janeiro.

UFABC - Universidade Federal do ABC

UFF - Universidade Federal Fluminense

UFRJ - Universidade Federal do Rio de Janeiro

UNESP - Universidade Estadual Paulista

UNICAMP - Universidade Estadual de Campinas

UNIRIO - Universidade Federal do Estado do Rio de Janeiro

USP - Universidade de São Paulo

DM - Departamento de Música da FFCLRP

EACH - Escola de Artes, Ciências e Humanidades

ECA - Escola de Comunicações e Artes

EEFE - Escola de Educação Física e Esporte

EEFERP - Escola de Educação Física e Esporte de Ribeirão Preto

ESALQ - Escola Superior de Agricultura Luiz de Queiroz

FD - Faculdade de Direito

FEA - Faculdade de Economia, Administração, Contabilidade e Atuária FEARP - Faculdade de Economia, Administração e Contabilidade de Ribeirão Preto

FFCLRP - Faculdade de Filosofia, Ciências e Letras de Ribeirão Preto

FFLCH - Faculdade de Filosofia, Letras e Ciências Humanas

FM - Faculdade de Medicina

FMRP - Faculdade de Medicina de Ribeirão Preto

IAC - Instituto de Astronomia, Geofísica e Ciências Atmosféricas

IEA - Instituto de Estudos Avançados

IFSC - Instituto de Física de São Carlos

IME - Instituto de Matemática e Estatística

NAP-CIPEM - Núcleo de Pesquisa em Ciências da Performance do DM-FFCLRP

POLI - Escola Politécnica

SO - Secretaria Geral da USP 


\section{Apresentação}

Non est philosophia populare artificium nec ostentationi paratum: non in verbis, sed in rebus est.

A filosofia não é um artifício público, nem está disposta à ostentação: ela não existe nas palavras, mas nas ações.

(Sêneca, Cartas a Lucílio, II, 16.3)'.

Aristóteles (século IV a.C.), em seus textos, costumava expor, inicialmente, os assuntos a serem tratados, antes de desenvolvê-los. Assim, priorizava a organização textual para não suscitar expectativas incorretas a um público não esperado, tendo em vista o sucesso da arguição. Diferentemente do filósofo de Estagira e de seus epígonos, Platão (século V-IV a. C.) evitava adiantar o assunto de suas palestras, buscando, por assim dizer, algum efeito paradoxal (talvez para fins de crítica ou de provocação?). Em vista disso, um dos mais importantes discípulos de Aristóteles, Aristóxeno de Tarento (século IV a. C.), ao explicar sobre a organização de seu tratado sobre Harmonia (Armonika Stoikheia), desaconselha a estratégia de Platão. Diz o músico de Tarento:

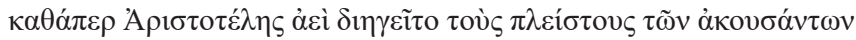

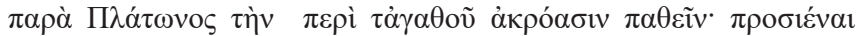

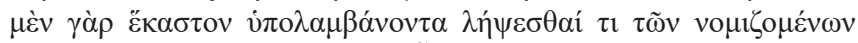

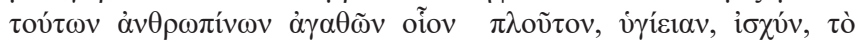

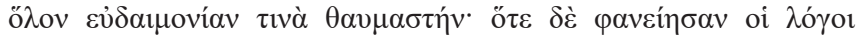

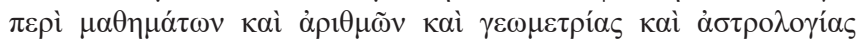

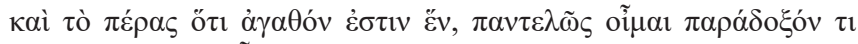

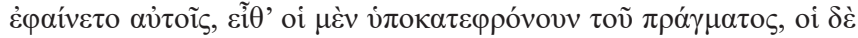

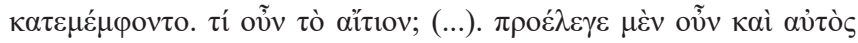

I SÉNĖQUE. Lettres à Lucilius. Tome I: Livres I-IV. Texte établi par François Préchac. Paris: Les Belles Lettres, 2017. Nesta seção, todas as traduções são nossas.

\section{0}




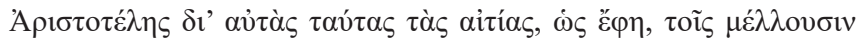

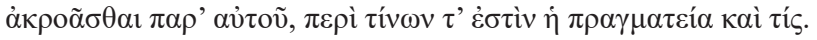

Como Aristóteles costumava nos contar, a maioria dos ouvintes que tinha participado da palestra de Platão sobre o bem [agathós] esperava obter algo daquelas coisas que consideravam boas aos homens, tais quais a riqueza [ploûtos], a saúde [hygieia] e a força [ischýn]; em suma, alguma felicidade de se admirar. Porém, eram reveladas palavras sobre Matemática, Aritmética, Geometria e Astronomia, e, no final, sobre o bem ser uno. Creio que isso tenha thes parecido totalmente paradoxal. Consequentemente, muitos olhavam as lições com desprezo, já outros as censuravam. Agora, por qual motivo? (...). Assim então, em função dessas mesmas razões, também o próprio Aristóteles, como afirmava, expunha um prólogo sobre o assunto e sobre a palestra ao público destinado a ouvi-lo.

(Aristóxeno, Elementos de Harmonia, II, 30-31)2.

Sob uma metodologia contraditória, Platão esclarece-nos que, para que um cidadão possa voltar-se às coisas boas, não é dinheiro ou força física que ele deve buscar, mas ciência, tal qual o conhecimento dos números e as razões do espaço físico, bem como a lógica dos planetas, dentre outros campos do saber. Ou seja, o conhecimento é mais propício ao bem e à revelação da verdade, em busca da essência do ser. Da mesma forma, a provocação platônica parece nos mostrar que as pessoas interessadas em prosperidade ou em uma felicidade admirável aos olhos dos outros tratavam o conhecimento com desdém ou com censura, recusando-o (diferentemente do que acontece hoje em dia). Se as lições de Platão desagradavam ao público desinteressado, que atestava o fracasso de suas palestras pela divergência de expectativas, ao mesmo tempo, com a provocação, revelavam-se os vícios dos ouvintes. Portanto, quiçá com o insucesso da arguição, Platão ensinava algo a mais do que números.

Não parece ao ateniense, portanto, que os verdadeiros bens à humanidade sejam materiais, senão, antes, aqueles mais abstratos, voltados à inteligência, que culminam, efetivamente, no senso de bem

2 MARQUARD, Paul. Die harmonischen Fragmente des Aristoxenus. Berlin: Weidmannsche Buchhandlung, 1868. 
comum. Em se desdobrando as metáforas, se a universidade, enquanto unidade, deseja algum bem, em sua missão científica, artística, filosófica, deve voltar-se totalmente ao conhecimento em diversos campos, e nunca às vontades daqueles que desejam riqueza, cargo ou poder. Afinal, discursos e métricas de índole competitiva e individualista, como o da produtividade e da precarização do ensino, distorcem a essência do pensamento científico, artístico e filosófico.

Em um exemplo mais pontual, quão comum, hoje, ouve-se falar de estudantes que buscam a Pós-Graduação com a expectativa de fortalecer o currículo ou a carreira, não necessariamente por amor às ciências, às artes e à filosofia? Em que medida as atuais avaliações, os rankings universitários, as divisões das áreas estanques do conhecimento em Exatas, Biológicas e Humanas, a precarização da educação básica e superior, com a sua consequente mercadologização, a redução dos departamentos, a falta de contratação e a extinção de cursos, tais quais grego, latim, indiano antigo, filosofia, dentre outros de suma importância, somados a narcisismos que desintegram departamentos, não são posturas totalmente anticientíficas, antiartísticas e antifilosóficas? Da mesma forma, essas distorções não impediriam a boa formação de alunos, a dignidade no exercício profissional, na preservação da autonomia universitária e no trabalho conjunto, haja vista a tríade "ensino, pesquisa e extensão", conforme Art. 207 da Constituição de $1988^{3}$ ? Em suma, as posturas nefastas não teriam como consequência irreversivel uma sociedade mais abrutecida, desigual, preconceituosa, escravizante, supersticiosa e precária?

Preocupado com os rumos da universidade, este dossiê apresenta as falas de professores e de convidados que participaram dos debates sobre os problemas da avaliação do conhecimento por meio de métricas redutivas, da fragmentação do saber em áreas isoladas que não mais conversam entre si e da exclusão de outras formas de expressão científica, além do paper. Tendo em vista as diversas disciplinas, sem desconsiderar nenhum campo do conhecimento, promoveu-se um debate fundamental sobre os caminhos que a Universidade vem percorrendo rumo ao esquecimento da arte, da liberdade e da autonomia. No entanto, sem deixar de notar, também, os ganhos e as melhorias, não se apresentou um discurso pessimista ou meramente crítico, que queira

3 Pode-se consultar sobre essa disposição na página do Senado Federal, no seguinte endereço eletrônico: <https://www.senado.leg.br/atividade/const/con 1988/ con 1988_18.02.2016/art_207_asp>. 
culpabilizar instâncias superiores ou inferiores, senão se colocaram diálogos que queiram reconhecer e solucionar problemas. Nesse espírito, - Manifesto de Leiden, um documento crítico sobre métricas de pesquisa, é mencionado inúmeras vezes nas falas dos professores ao longo dos três encontros.

Nesses debates, não somente sobre as artes, mas em consideração à universalidade do conhecimento, percebeu-se uma confluência de posicionamentos contra o descaso com as ciências e com o bem-estar universitário. Os professores de diversas faculdades, em parceria com as reitorias, dirigentes e coordenadores ${ }^{4}$, compartilharam, pois, dos mesmos sofrimentos e das mesmas aflições que os rankings universitários e os ditames mercadológicos provocam no exercício de ensino, pesquisa e extensão.

Como tarefa do pensamento a respeito dessas questões, foram realizados três encontros, na Sala Alfredo Bosi do Instituto de Estudos Avançados da Universidade de São Paulo (IEA-USP). Coordenados pelo Prof. Dr. Rubens Russomanno Ricciardi, os debates adotaram um formato livre, em que todos aqueles que estavam presentes ou que acompanhavam de forma remota puderam dar opiniões e fazer perguntas. Nesse sentido, procurou-se promover a liberdade do debate, sem qualquer rigidez. Ressalta-se que os textos que compõem este dossiê estão em sua forma transcrita e concisa, a partir da gravação dos encontros. Em sua finalização, foram retirados os excessos da oralidade $e$ as passagens pro forma. Também foram feitos ajustes no tocante aos recursos coesivos e normativos da língua portuguesa, mantendo-se o teor das argumentações, sem interferir no tom original.

primeiro encontro, que ocorreu no dia 13 de abril de 2018 , no período vespertino, teve o objetivo de levantar problemas iniciais e conflitos de áreas sobre as métricas redutivas e sobre a fragmentação do conhecimento, cujo reflexo sejam unidades universitárias mais isoladas e menos unidas. Discutiu-se sobre o efeito da competição universitária, mediada pelo discurso estéril da produtividade, e sobre - desconhecimento de outras áreas ou unidades pelos docentes, cujo afastamento gera, pois, a desunião dos departamentos e a desintegração do conhecimento. Nesse sentido, o campo transdisciplinar

4 Embora se destaquem, muitas vezes, as relações entre docentes, coordenadores e diretores, consideram-se, também, todas as instâncias universitárias, que dialogam com as Unidades, da Reitoria aos Museus, Órgãos, Institutos e Entidades associadas.

\section{3}

REV. TULHA, RIBEIRÃO PRETO, v. 7, n. I pp. 236-392, jan.-jun. 2021 
(ou interdisciplinar, como preferem alguns) pode ser um caminho à reintegração das disciplinas, assim como a presença de professores de áreas distintas em um mesmo departamento e em eventos científicos.

Em diálogo, as áreas do conhecimento exigem, portanto, um trabalho em conjunto, considerando todas as hierarquias e funções dentro da academia, sem exclusão. Por isso, não é honesto relegar às instâncias superiores toda a responsabilidade de mudança. Por sua vez, as Unidades são capazes de apontar, de fato, as suas necessidades $e$ as melhores formas de serem avaliadas. Caso contrário, a falta de diálogo pode resultar nos mais variados equívocos, que vão desde erros na contratação de docentes até à má formação de alunos de Graduação e Pós-Graduação, cada vez mais habituados ao discurso da produtividade, em que interessa mais publicar do que ler e aprender, em dependência de certificados, diplomas e papéis. Por isso, questionam-se avaliações que desvalorizem ou não reconheçam palestras e concertos, por exemplo, como uma atividade importante. Consequentemente, um filósofo sério e ético que deu muitas palestras e publicou livros e ensaios, mas poucos artigos em periódicos, tem menos chance de ser aprovado em um concurso do que um candidato que fez pesquisa preocupando-se apenas com publicações em periódicos, porque atua somente em função de tabelas de recompensa ou de um currículo o mais competitivo. Da mesma forma, textos mais curtos e padronizados têm preferência em relação a ensaios mais extensos, que raramente encontram espaço para publicação (quantos periódicos aceitam artigos com mais de 9 mil palavras?). Por conseguinte, o modelo de paper foi padronizado, sob a hegemonia das "ciências duras", no qual o filósofo, o dançarino e o químico devem escrever da mesma forma, sob o mesmo limite de palavras). Nesse sentido, a universidade precisa de expedientes que impeçam procedimentos e hábitos viciosos no fazer científico, como a prática da pesquisa carreirista, aquela interessada somente em currículo e em publicação bem avaliada e internacional (e sempre em inglês!).

Expostos os principais problemas das áreas do conhecimento pelos docentes, o debate inicial teve sequência em um segundo encontro, em que se ouviram mais professores. Assim, a etapa seguinte, que ocorreu no dia 29 de junho de 2018, a partir das questões levantadas anteriormente, procurou canalizá-las em uma discussão mais pontual. Os assuntos encaminharam-se para além do problema da divisão das áreas do conhecimento, em que, por exemplo, a Música apartou-se da Matemática (contrariamente à sua união, como era no 
Quadrivium) e a Física, da Biologia, entre outros exemplos. Afinal, se a Antropologia é considerada "Humanas", seria a Química "desumana"? Quão adventícia seria a contratação de um filósofo para docente de um Departamento de Física? Profissionais das Letras não poderiam atuar em distintas áreas, na medida em que todos os setores produzem gêneros textuais e necessitam da educação da escrita e do estudo de línguas e literaturas? E os esportes? Até que ponto as determinações estereotípicas das áreas do conhecimento não resultam em deformações do saber e em exclusões? lgualmente, em que medida as áreas do conhecimento não são balizadas por estereótipos? Ademais, essas divisões também não são responsáveis por alterar a estrutura social, educacional e laboral da sociedade? Quais são as consequências de uma divisão incorreta das áreas do conhecimento e do discurso da produtividade de papers, além de permitir injustiças na contratação de docentes e de promover a alienação do saber? Em sentido metafórico, em menção a Platão, não estaríamos, logo, cada vez mais preocupados com "riquezas" [ploûtos] ou benefícios próprios, para a admiração alheia, muito mais do que com ciências, artes, esportes, filosofia, educação etc.? Em um plano mítico-metafórico, não seria, por esse motivo, que Hércules, ascendendo ao Olimpo, cumprimentou todos os deuses, menos Pluto 5 , na famosa fábula de Esopo 6 ? Alegava o novo deus que, quando estava junto dos homens, Pluto costumava frequentar os maus e perversos.

Com participação expressiva do público, os debates encaminharam-se em sua proposta de liberdade e autonomia, culminando em uma discussão política, para além da teórica ou técnica, em discurso contra a demagogia e a burocracia que desrespeite o trabalho do professor. Ademais, ficou claro que a dicotomia entre teoria e prática é insensata e resulta em um desmerecimento do conhecimento, em que o discurso "teórico" é visto como inutilidade, e a "prática", com preconceitos. Até que ponto a ingenuidade de contrapor conhecimento teórico e prático não tem reflexos, também, no Ensino Fundamental e Médio, em que a escola é considerada inútil porque não ensina a fazer imposto de renda ou a consertar uma torneira, preparando adultos práticos?

É oportuno lembrar-nos, novamente, de Platão, a quem o cidadão que deseja alcançar a verdade revelada sobre o mundo e a essência

5 Deus da riqueza.

6 ESOPO. Fábulas completas. Tradução de Maria Celeste C. Dezotti. São Paulo: Cosac Naify, 2013, p. 234.

\section{5}

REV. TULHA, RIBEIRÃO PRETO, v. 7, n. I pp. 236-392, jan.jun. 2021 
do ser, dentre outras disciplinas, deve aprender sobre os números, compreendendo a sua natureza pelo pensamento, por assim dizer, em sua configuração total, e não como fazem os comerciantes, vendedores ou negociadores, de modo utilitário e sem profundidade, porque estão distantes da verdade crítico-filosófica dos números. Em outras palavras, o pensamento é mais propício para atingir a verdade filosófica e a percepção crítica do mundo, com inteligência. Ou seja, a escola não deve existir somente para ensinar o aluno, um futuro comerciante, a "dar o troco" e a fazer a "caderneta".

É preciso deixar claro que o pensamento, em suas associações abstratas, não significa ausência de prática. Para Platão, em uma esfera política, enquanto bem-estar da cidade, o governante, por exemplo, que desconheça a natureza dos números, em sua intimidade com o pensamento e o mundo, seria incapaz de ser justo e de governar adequadamente.

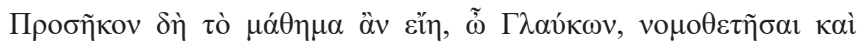

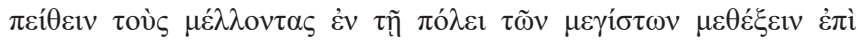

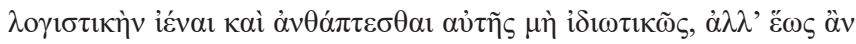

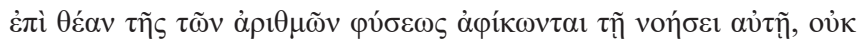

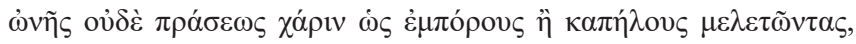

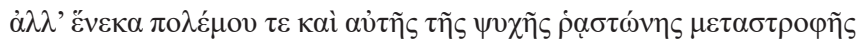

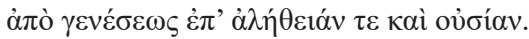

I certo, não seria conveniente, ó Glauco, que essa ciência seja instituída por lei e que se convençam os cidadãos que participarão das grandes decisões desta cidade a aprender o cálculo, dedicando-se aos números não de modo inexperiente, mas a ponto de examinar a sua natureza pelo próprio pensamento, e não pelo prazer da compra e da venda, como praticam os mercadores ou os comerciantes, senão por causa da guerra e da facilidade de transformar a própria consciência, da origem à revelação da verdade e do ser?

(Platão, A República, 525c)?.

7 PLATON. Oeuvres complètes. La République. Livres IV-VII. Texte établi et traduit par Emile Chambry. Paris: Les Belles Lettres, 2015. 
Assim, o conhecimento é uma conjunção em que pensamento e realização são indissociáveis e não podem ser reduzidos à oposição entre tarefas práticas e tarefas teóricas. Nesse viés, a divisão entre teoria e prática não faz nenhum sentido, pois o conhecimento da natureza das coisas (em sua simbiose concreto-abstrata) é sempre um todo, sem uma parte teórica distinta de uma prática, como não se separam os lados de uma folha de papel. Na verdade, o dito "prático", de aspirações industriais e comerciais, é valor atribuido à produção de bens materiais ou de bens virtuais preocupados com consumo e lucro. Nessa esteira, a tecnologia torna-se indústria da tecnologia, quando desprovida de liames com o bem-estar, a ética e a postura críticofilosófica. A educação e o conhecimento, nesse sentido, não podem confundir tecnologia com indústria da tecnologia, nem educação com tecnologização (em que educar seja promover mercado e indústria da tecnologia). Da mesma forma, "teoria e prática", por assim dizer, diferemse de utilitarismo, como se uma educação "prática" conduzisse às tarefas ordinárias ou cotidianas, que nos afastam de nossa essência enquanto seres, em lembrança ao pensamento de Heidegger.

Por essa razão, para Sêneca, conforme a epígrafe, a Filosofia é, por essência, ação, embora muitos a consideram uma área estritamente teórica. Os estereótipos de curso, dessa forma, enraízam-se rompendo a epistemologia, com consequências nefastas ao aprendizado, às ciências e à compreensão de mundo. Assim, entende-se que a filosofia não é ou teórica ou prática, senão conhecimento, sempre imbuido de relações teórico-práticas indissociáveis, assim como não existe medicina sem teoria e prática, nem teatro, nem esportes, nem matemática, nem dança, nem música, nem conhecimento algum. Afinal, a arte existe enquanto obra de arte, pois, na "teoria absoluta", nada existe, nem ela mesma. Um exercício de cálculo é uma atividade teórica e prática (porque há sempre um saber-fazer), independentemente da produção de objetos ou serviços. Em que medida lecionar poderia ser uma atividade somente teórica ou somente prática? Como a pesquisa de um pianista intérprete poderá ser somente teórica ou somente prática? Por isso, esse aspecto "prático", inconcebível sem contemplação intelectual (logo, theorica ${ }^{8}$ ), não deve ser reduzido a mero utilitarismo. Um jovem, no Ensino Médio, que condena a escola porque nunca usará a fórmula de Bháskara

8 Vale lembrar que a palavra latina theoria pressupõe um ato contemplativo e

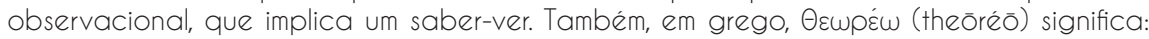
contemplo, olho, observo atentamente, examino com rigor, reflito, além de outras possibilidades semânticas.

\section{7}

REV. TULHA, RIBEIRÃO PRETO, v. 7, n. I pp. 236-392, jan.-jun. 2021 
em sua vida ainda não teve a oportunidade de entender o que é ciência e filosofia. A muitos jovens, a avaliação, finalidade autoritária da educação, tornou-se o único sentido do conhecimento: passar em provas e entrevistas para garantir sobrevivência ou assegurar competição, sempre no ditame do sucesso e do fracasso. Nessa lógica, destrói-se tudo, exceto a ganância.

Essas questões não estão distantes de uma Pós-Graduação, em que a necessidade de publicação de papers em revistas com qualificações alfabéticas pode acabar superando o desejo de fazer ciência de fato, estabelecendo uma cultura da produtividade e da competição, que molda as linhas de pesquisa, produzidas para produzir. Da mesma forma, a tentativa de estabelecer outras formas de publicação, com outros métodos, acaba-se em preconceitos, que podem impedir, por exemplo, a abertura de novos cursos de Pós-Graduação, como a resistência contra o Mestrado Profissional, que tem, igualmente, pesquisa, mas pode se expressar de outras formas, além do artigo científico e da dissertação. De fato, outros meios de expressão, para além do paper, ainda são desvalorizados ou sequer reconhecidos. Por exemplo, um músico, como resultado de sua pesquisa diária, pode compor uma obra artística, para além do discurso metodológico-positivista, em que a poíesis, essência da arte, possa ser contemplada. Por isso, é urgente trazer às universidades novos modelos de produção científica, que não fiquem ensimesmados com a cultura positivista, a fim de permitir ensejo artístico ou outras possibilidades de expressão.

terceiro encontro, que ocorreu no dia 04 de outubro de 2018 , conduziu a discussão a questões mais pontuais, como o problema de as linhas de pesquisa engessarem o pesquisador e de as métricas arbitrárias ferirem a liberdade da pesquisa. Como consequência, há uma tendência em valorizar mais o pesquisador monotemático e hiperespecialista, enquanto restrito à sua linha de pesquisa e ao seu departamento, do que o pensamento plural e o perfil polímata do docente, que seja capaz de versar entre departamentos. Infelizmente, o pesquisador multifário ainda é tratado como alguém com dificuldade de decisão na carreira. Por essa razão, a poligrafia deve ser incentivada no ambiente universitário, e não discriminada.

Há, também, o problema de a metodologia científica ser reduzida à mera oposição "quantitativo x qualitativo". Por isso, é importante levantar argumentos contra os métodos que reduzam a ciência a

\section{8}

REV. TULHA, RIBEIRÃO PRETO, v. 7, n. I pp. 236-392, jan.-jun. 2021 
categorias setoriais. Neles, inverte-se a relação de causalidade, em que o método gera a pesquisa, esquecendo-se, na verdade, de que a pesquisa, sob liberdade, pode gerar seus próprios métodos. Nesse sentido, deve-se compreender pesquisa sempre enquanto superação do método, caso não queiramos reduzir ciência a procedimento, destituída de pensamento crítico-filosófico. $\bigcirc$ problema, para além do método per se, é a imposição de sistemas estanques, com forte armamento avaliatório, que desautorizam, inclusive em âmbito institucional, a postura multitemática do pesquisador e as propostas pluriepistêmicas de pesquisa, em diálogo essencialmente transdisciplinar, como, na verdade, faziam os antigos gregos e romanos e toda a ldade Média, em mais de vinte séculos de História. Afinal, Empédocles (século V a.C.) era físico, matemático, filósofo ou poeta?? Aristóxeno (século IV a.C.) era filósofo, músico, historiador ou pedagogo? Da Vinci (1452-1519) era filósofo, engenheiro, anatomista, arquiteto ou pintor? Em qual departamento Da Vinci poderia ser contratado: Artes visuais, Medicina, Engenharia ou em nenhum porque ele não publicava papers?

Com a lógica obscurecida, os departamentos fragmentados e as linhas de pesquisa estanques reduzem a ciência a repartições de áreas, com critérios atribuídos a priori do conhecimento, confundindose currículo com disciplina. As consequências dessas sistematizações rígidas, que não admitem o método enquanto possibilidade, trazem resultados nocivos quer à pesquisa quer, também, à educação, uma vez que não se separam pesquisa, ensino e extensão. Foi tarefa, portanto, do debate fazer um alerta contra a postura reducionista e narcisista nas atividades científicas, na medida em que se transformam ciência e educação em indústrias do conhecimento, retirando do pesquisador e do professor a autonomia de pensamento e a liberdade, inclusive, dentro de sua própria linha de pesquisa. Ainda se aconselham professores a não fazer nada além do que propõe a sua linha de pesquisa. Fora dela, a produção é mal vista.

Com todas essas discussões, transcritas neste documento, percebeu-se, assim, a necessidade de um quarto encontro para discutir questões específicas sobre pesquisa e artes, com todas as áreas artísticas em reunião. Encerrado o ciclo dos três primeiros encontros, foi realizado, no dia $\mathrm{O6}$ de novembro de 2018, no Auditório Nicolau Sevcenko do Departamento de História da FFLCH, o seminário "A Pesquisa

9 Reduzem-se as funções para evitar uma listagem.

\section{9}

REV. TULHA, RIBEIRÃO PRETO, v. 7, n. 1 pp. 236-392, jan.-jun. 2021 
em Artes: uma discussão conceitual". Esse evento foi gravado e disposto na Plataforma Youtube ${ }^{10}$. Do mesmo modo, foram feitas a transcrição e a organização do texto do evento em dossiê específico, já publicado pela Revista da Tulhal'.

Em suma, esses seminários apresentam discussões fulcrais à universidade, que deve se proteger dos ataques contra a autonomia e a liberdade, garantindo condições dignas de trabalho aos professores, asseidade universitária, qualidade na formação dos estudantes e promoção de bem-estar. Para isso, é preciso repensar o caminho da universidade, que se encontra direcionada a uma mercadologização estéril, que precariza as ciências, as artes, os esportes, a filosofia, dentre as mais diversas áreas do saber. Assim como agia o público desprevenido de Platão, até que ponto ainda não há desdém ou censura ao conhecimento? Quão divergentes são as vias contrárias ao pensamento ou à inteligência?

Em suma, sob desejo de liberdade e autonomia de pesquisa, os três encontros transcritos e organizados neste dossiê procuraram levantar questões fundamentais relacionadas às áreas do conhecimento e às avaliações. É urgente, pois, repensar o critério único de avaliação que desconsidera a diversidade do pensamento. Afinal, o resultado de uma pesquisa não precisa ser veiculado somente por papers, mas por outros caminhos de expressão, incluindo as próprias obras de arte, que exigem, igualmente, pesquisa. Não se trata de criticar a pesquisa que necessita da produção de artigos, mas de questionar a desvalorização ou exclusão de outras formas de realização científica, incluindo ensaios, livros, recitais, gravações etc. Como explica o Prof. Dr. Rubens Ricciardi, em uma de suas falas neste dossiê, a universidade é, atualmente, o lugar ideal para viabilizar a arte, enquanto instituição contemporânea que substitui o que foi a lgreja e a Nobreza, em relação às atividades artísticas do passado. Afinal, fora da universidade, o que predomina é a kulturindustrie (indústria da cultura). Enquanto resistência, a universidade não pode sucumbir aos shows que não tenham compromisso filosófico, artístico, científico, ético. Ela deve ser o espaço, por excelência, da arte.

10 Página de acesso ao Seminário:

$<$ https://www.youtube.com/watch? v=4UygFi-Un|UEt= $\mid 9028 \mathrm{~s}>$.

I 1 dossiê pode ser encontrado em: VEICA, P. E. de B.; ROLNIK, D. A pesquisa em artes: uma discussão conceitual. Revista da Tulha, [S. I.], v. 6, n. 2, p. 247-305, 2020. DOI: 10.1 1606/ issn.2447-7 | 17.rt.2020.179973. Disponivel em: <https://www.revistas.usp.br/revistadatulha/ article/view/179973 >. Acesso em: 29 jun. 2021. 
Da mesma forma, os encargos burocráticos não podem tomar o tempo do professor-pesquisador-artista, que mal se concentra na própria pesquisa, porque está ocupado com atividades impostas que não deveriam ser suas.

Frisa-se, mais uma vez, a importância do Manifesto de Leiden que se coloca contra os critérios redutivos de métrica e os rankings internacionais, em geral, preocupados com outras questões que não sejam acadêmicas. Por conseguinte, as pesquisas nas artes são reduzidas, desincentivadas ou esquecidas, em função de preconceitos que impedem novas configurações de pesquisa, sob tratamento diferenciado e inventivo. Afinal, se o conhecimento é variado e, ao mesmo tempo, não fragmentado, por que a produção de pesquisa deve se pautar por modelos reduzidos e estanques, que privilegiam uma área em detrimento de outra? Nesse sentido, devemos defender, sempre, a liberdade, o engenho e a invenção. Por fim, a maior missão desses encontros é transformar as palavras em realizações, fazendo a universidade efetivamente mais resistente contra os ataques às ciências, às artes, aos esportes e à filosofia, a favor da liberdade e da autonomia.

Paulo Eduardo de Barros Veiga ${ }^{12}$

12 Professor colaborador e pós-doutorando do Departamento de Música da Faculdade de Filosofia, Ciências e Letras de Ribeirão Preto da Universidade de São Paulo. Sob apoio da FAPESP, é pesquisador junto ao Núcleo de Pesquisa em Ciências da Performance (NAPCIPEM). Processo n 20 18/0 $1418-2$, Fundação de Amparo à Pesquisa do Estado de São Paulo (FAPESP). 


\section{Seminário (Re)discussão sobre as grandes áreas do conhecimento}

IEA-USP

13 de abril de 2018

Link de acesso ao evento:

https://www.youtube.com/watch? v=m5IzUOeM I AOE $t=7035 \mathrm{~s}$

Local: Sala Alfredo Bosi - Instituto de Estudos Avançados da Universidade de São Paulo

Coordenação: Rubens Russomanno Ricciardi (DM-FFCLRP-USP)

Participação dos Professores da USP

Ana Cristina Zimmermann (EEFE)

André Luis Giovanini Micheletti (FFCLRP)

Diego Antonio Falceta Conçalves (EACH)

Fritz Cavalcante Huguenin (FFCLRP)

Ignacio Maria Poveda Velasco (FD)

Luís Antonio Eugenio Afonso Montanha (ECA)

Oscar João Abdounur (IME)

Paulo Eduardo de Barros Veiga (FFCLRP, pós-doutorando)

Ricardo Figueiredo Bologna (ECA)

Tito José Bonagamba (IFSC)

Convidados externos

Adelaide Faljoni-Alario (UFABC, CAPES)

Alexandre da Silva Costa (UFF)

Icléia Thiesen (UNIRIO)

Et alii. 


\section{Abertura}

\section{1) Prof. Dr. Rubens Russomanno Ricciardi (FFCLRP)}

Este seminário é uma iniciativa de vários professores da USP, incluindo os convidados presentes, para que possamos levantar debates com liberdade. Não é como nos conselhos departamentais, nas congregações ou nos conselhos técnicos-administrativos, que são, geralmente, atividades da burocracia cotidiana, atreladas, justamente, à administração da Universidade. $O$ IEA foi fundado como um grande instituto de liberdade para pensar novos horizontes para a Universidade. Inclusive, agradeço o apoio do Prof. Paulo Saldiva (FM-USP), que, brilhantemente, dirige esta instituição. Sendo a USP uma universidade de ponta na América Latina, essas discussões podem se desdobrar em boas sugestões quanto ao aspecto construtivo de um trabalho em conjunto nas diversas áreas do conhecimento.

Em sintese, este encontro não tem um formato rígido, senão é constituido por algumas fases iniciais, em que possamos trocar ideias com liberdade, como um primeiro encontro. Quem sabe, possamos prosperar a um projeto mais efetivo, ao levantar um documento que seja uma primeira reunião, a fim de pensar o que pode ser aperfeiçoado na Universidade. Haverá falas iniciais antes de a palavra ser aberta a todos os presentes.

Antes de apresentar os convidados do Rio de Janeiro que vieram colaborar conosco, passo a palavra ao Prof. Ignacio Poveda, que é secretário-geral desta Universidade e professor titular da Faculdade de Direito do Largo São Francisco. Ainda fazendo parte da Congregação, construiu, em Ribeirão Preto, uma Faculdade brilhante, a Faculdade de Direito de Ribeirão Preto, onde há, inclusive, um auditório que muito serve à música, em benefício da integração entre as áreas, no caso, o Direito e a Música. Mais uma vez, obrigado pelo apoio do professor Poveda, sempre muito próximo das artes. 


\section{Falas iniciais}

2) Prof. Dr. Ignacio Maria Poveda Velasco (FD, SC)

Em primeiro lugar, eu gostaria de dar as boas-vindas a todos que aqui estão e aos que nos acompanham também pela transmissão, em nome da Universidade e, por extensão, do Instituto de Estudos Avançados. Também, gostaria de parabenizar por essa iniciativa tanto - IEA, quanto o Núcleo de Pesquisa em Ciências da Performance (NAP(IPEM), do qual o Prof. Rubens Ricciardi é coordenador, na Faculdade de Filosofia, Ciências e Letras de Ribeirão Preto, Departamento de Música.

A área do Direito é muito consolidada, muito antiga. Antes mesmo de haver Universidades - universitas studiorum - já havia Escola de Direito, desde a Roma antiga, passando por Beirute. Por exemplo, destaco os juristas da "Escola de Berito", como se chamava na época, que foram responsáveis pela compilação de todo o direito romano, e - Corpus luris Civilis, no século VI, que preservou a tradição do direito romano para a posteridade e a modernidade. Mas, por ser uma área muito fechada e muito definida, ela é também uma área, muitas vezes, avessa à realidade multifacetária, que é a realidade do mundo em que nós vivemos.

Há alguns anos, quando eu era um jovem professor da Faculdade de Direito do Largo São Francisco, o Diretor, na época, falou: “Ignacio, eu queria contar com você para presidir a Comissão de Informática da Faculdade de Direito". Eu não tinha noção do assunto; era a época do 286, 386, impressora matricial etc. Eu comento isso porque, enquanto Presidente da Comissão de Informática da Faculdade de Direito, foi a primeira vez que eu vim ao campus para participar de uma reunião em que havia um físico, um arquiteto, um médico, um psicólogo. Esse contato com as diferentes áreas do conhecimento - desde aquela época-tem sido um motivo de reflexão e de interesse, porque nós temos que pensar que a realidade do conhecimento é uma só - vamos chamar assim, a verdade, não no sentido metafísico. A realidade é o que é; porém, ela é multifacetada. Por essa razão, muitas vezes, seja por motivos didáticos, seja por motivos metodológicos, nós tendemos a fragmentar. A realidade, porém, é uma só. Tomo, como exemplo, a situação em que um médico atende ao seu paciente: ele pode ser especialista em rim, 
mas a pessoa é uma só, o doente é um só. Nós sabemos que toda a linha de humanização da medicina, que ganha força, coloca o foco no paciente, na pessoa humana, na pessoa que sofre daquela patologia. lgualmente, penso que, em relação ao conhecimento, o fenômeno seja semelhante. Por força, foca-se em um aspecto da realidade das coisas, mas a realidade das coisas é uma só. Por isso, as interações e o diálogo entre as diferentes áreas do conhecimento são necessários.

A discussão é mais ampla do que uma questão propriamente teórica ou intelectual. A questão da rediscussão das grandes áreas do conhecimento talvez atenda mais à ordem prática. Ou seja, de que modo a definição das grandes áreas partilha o conhecimento ou possibilita a interação? $\bigcirc$ que mais preocupa é a forma como, a partir de uma definição de áreas de conhecimento, é feita uma avaliação. $\bigcirc$ debate envolve, portanto, tudo aquilo que decorre da avaliação, inclusive as contratações de docentes nas diferentes áreas. Por isso, a iniciativa do Prof. Rubens Ricciardi e do Prof. Paulo Saldiva é muito bem-vinda.

3) Profa. Dra. Icléia Thiesen (UNIRIO)।3

Parece que aqui se inicia uma pesquisa. Afinal, estamos em busca de problemas, tal qual a etapa inicial de um projeto de pesquisa. Eu tenho dupla formação, Biblioteconomia e Museologia. A minha PósGraduação foi na área de Ciência da Informação. Além disso, trabalhei com o tema da memória no Departamento de História. Portanto, eu sou passageira das fronteiras, para o bem e para o mal. Então, é desses caminhos percorridos de que eu falo. Eu busquei um fio para me expressar aqui justamente porque eu não tenho domínio sobre vários temas que foram levantados ao longo da formação desse grupo e até mesmo sobre a própria questão das humanidades hoje. Este é um tema que está na ordem do dia, em função de uma proposta já registrada no Senado, nesta semana, que trata da extinção de cursos de Filosofia, História, Geografia, Sociologia, Artes e Artes Cênicas das Universidades Públicas, restringindo as áreas às Universidades privadas. A proposta é

13 A Profa. Dra. Icléia Thiesen, expandindo a sua fala, adequou-a em formato de artigo, publicado à parte, neste mesmo volume, pela Revista da Tulha. A quem desejar, todas as referências mencionadas encontram-se nessa publicação.

\section{5}

REV. TULHA, RIBEIRÃO PRETO, v. 7, n. 1 pp. 236-392, jan.-jun. 2021 
essa, presencialmente ou a distância, de modo que se ascende o alerta laranja ou vermelho. Logo, este seminário é extremamente relevante.

Eu me detive na questão de levantar caminhos que possam nos mostrar o processo histórico que vem definindo o lugar de cada campo do conhecimento, numa estrutura e hierarquização atual, não apenas no Brasil, mas em diversos outros países. Uma pergunta inicial: o que se passou desde que as áreas foram ganhando as atuais denominações? Certamente o conhecimento produzido ao longo do tempo transformou esses conceitos, assim como as práticas. Mas precisamos conhecer a Ciência na História mais do que a História das Ciências. No início desses trabalhos, quando o grupo foi se constituindo, a minha ideia foi pensar na tabela de áreas de conhecimento, pois não podemos ignorá-la. Refiro-me à tabela de áreas usadas tanto pelo CNPa como pela CAPES, que são os dois órgãos que se encarregam, em âmbito federal, dos pesquisadores e dos programas de Pós-Graduação, respectivamente.

Essa classificação das áreas é também usada na definição dos Comitês de Assessoramento do CNPQ e são também formadoras e agregadoras de áreas junto ao CNPq. Cito uma colega que participou de uma comissão de estudos realizada no CNPa em 2005, que visava à reestruturação das áreas de conhecimento. A Profa. Rosali Fernandes chegou a publicar um artigo sobre a Ciência da Informação dentro dessa reestruturação. De uma forma geral, ela diz que essa tabela é usada para fins de avaliação e gestão em níveis hierárquicos de agregação. A primeira versão dessa classificação data de 76; a segunda versão, de 82; e a versão de 84 está em vigor até hoje, tanto no CNPq, como na CAPES. Nas últimas décadas, foram várias as iniciativas de atualização ou mudança nessa tabela, mas, até o momento, permanece em vigor a de 84 .

Essas questões foram tratadas em 2005, como eu disse. Houve, nessa comissão, a presença do Vice-Presidente do CNPa de então, um representante da CAPES, outro da FINEP e mais dezessete representantes de áreas. Os trabalhos tiveram a duração de cerca de nove meses. Também, foram consultados programas de Pós-Graduação $e$ as associações científicas. $\bigcirc$ objetivo era menos filosófico e bem mais técnico, voltado, sobretudo, para classificação de projetos, de grupos de pesquisa, bolsistas. Como toda classificação tem um propósito, essa também tinha. De fato, não era uma comissão voltada para questões filosóficas prioritariamente. Houve muita discussão sobre 
interdisciplinaridade, trans, multi, pluridisciplinaridade e, sobretudo, a necessidade, que foi levantada por vários desses representantes, de considerar a História dos campos científicos integrantes dessas áreas. A tabela que veio depois foi muito pouco alterada. Esses trabalhos foram finalizados com relatório. Eu acho que essa recontextualização pode nos permitir entender o que está em jogo, em todas as iniciativas, nas reações e nos conflitos que são gerados no interior dessas áreas. Não podemos nos esquecer de que se trata de uma batalha. $\bigcirc$ próprio Michel Foucault sempre diz que o conhecimento é fruto de uma batalha.

Dada essa relevância do tema, é vital entender a estruturação e a hierarquização dessas áreas, porque elas definem critérios, critérios de avaliação da ciência e, mais recentemente, além da tecnologia, a chamada inovação, que também é uma inovação na denominação. São definidores, também, de recursos ao desenvolvimento de pesquisa dos países e constituem elementos de políticas científicas explícitas ou implícitas. Assim, é preciso que sejam compreendidas e problematizadas. Não há dúvida de que a classificação é vital em toda e qualquer ciência.

Há um outro aspecto interessante de ser discutido: a questão da articulação entre ensino e pesquisa, pesquisa e disciplina, isto é, estudar comunidades disciplinares que funcionam como fórum de discussão e avaliação mútua de resultados. Pressupõe-se, também, compreender o conjunto de regras, comportamentos, linguagens e sociabilidades. Como dizem as pesquisadoras francesas, que eu cito a seguir, cada disciplina tem seu éthos próprio, que marca a identidade de seus membros, sobretudo, na recusa da sedução de questões que excedem os limites da disciplina e ameaçam abri-la a intrusos. Trata-se de Isabelle Stengers e Bassualdi Vassan, que tem um livro intitulado "100 palavras para começar a pensar a ciência”. Elas dizem que essas disciplinas engendram, às vezes, uma ortodoxia, tendo como consequências fechamentos ou prisões disciplinares, o que explica, segundo elas, um apelo mundial à pluridisciplinaridade.

No Brasil, há um crescimento expressivo de cursos que integram a área interdisciplinar na CAPES, anteriormente denominada multidisciplinar. Por conseguinte, o fenômeno reflete não apenas um crescimento de cursos, o que seria explicado pela própria dinâmica da produção científica, que cresce exponencialmente, mas também uma complexa mudança identitária nas áreas do conhecimento, com o surgimento de 
novos problemas, por exemplo. Daí se diz que todas as áreas têm seus documentos de área. Na verdade, somos nós representados nessas instituições, que promovem atualizações periódicas em fóruns dos respectivos campos. Portanto, estamos representados nestes fóruns e precisamos atentar para essas práticas que fazem parte do fazer da ciência.

A proposta de uma epistemologia crítica, quando o conhecimento se pergunta sobre si mesmo, passa pelo estudo da institucionalização das diversas ciências e suas estruturas enquanto campos hegemônicos disputados em busca de reconhecimento, prestígio e recompensas. A avaliação da ciência desde o pós-guerra define critérios de cientificidade e, salvo engano, são incorporados e reproduzidos em diversos países, inclusive no Brasil, muitas vezes de forma acrítica, mas nem sempre, evidentemente. Desde a década de 60, usa-se uma série de conceitos ou noções para designar fenômenos que regem a ciência. Em Little Science, Big Science, Derek de Solla Price, livro publicado originalmente em 63, menciona o conhecido efeito Mateus na ciência, estabelecido por Merton, a partir da parábola dos dez talentos, no evangelho de Mateus: "porque a quem tem the será dado e terá abundância, mas ao que não tem, até o pouco que tem the será retirado". Fácil de ser identificado, o efeito Mateus na ciência constitui um desafio às políticas científicas engessadas e enviesadas na sua ortodoxia, pois que podem levar a distorções. Acrescente-se a esse ingrediente a transposição de característica da chamada Big Science para avaliação de pesquisadores, grupos de pesquisa, laboratórios, bolsas, prêmios etc.

Tais paradigmas determinam critérios de cientificidade, sistemas de recompensas, distinção etc. Tudo isso está na História e gera áreas hegemônicas e políticas científicas com resultados passiveis de contestação. Será que a régua que avalia a produção da ciência feita deixa de fora a ciência sendo feita (no sentido de Bruno Latour)? modo de produção do campo das humanidades pode ser identificado totalmente com o fazer de outros campos da ciência sem prejuízo do primeiro? Há ainda normas estabelecidas em determinada área que são impostas e se estendem a outras; é o caso, por exemplo, dos Comitês de Ética em Pesquisa, criados em instituições que realizam pesquisas com seres humanos. Das ciências médicas para as ciências humanas e sociais, a compreensão do que seja a proteção dos sujeitos da pesquisa têm causado inúmeros impactos nas pesquisas qualitativas. 
Longe de preservarem o sujeito da pesquisa, que poderia ser objeto de estigmatização, como ocorre de fato nas pesquisas médicas, tais normas redefinem estratégias metodológicas usadas nas ciências humanas e sociais, mas não apenas. A obrigatoriedade de preservar o anonimato na realização de entrevistas, tanto de história oral quanto outras modalidades, impede os estudos que abordam questões como identidade e memória. Nesse momento, falo de dentro do meu campo: nossos entrevistados falam em primeira pessoa e querem dizer os seus nomes; logo, os prejuízos são imensos.

A chamada scientometrics, mais tarde denominada bibliometria e mais recentemente métricas, mede a produção científica a partir de indicadores e critérios quantitativos. Porém, embora importantes na identificação de frentes de pesquisa, tendências e outros fenômenos que somente os grandes números podem manejar, o que fica de fora do sistema? Qual o lugar da diferença no sistema de avaliação da ciência? Há que se atentar tanto para a diferença como resistência quanto para a diferença que sofre resistência do sistema. Critérios puramente qualitativos respondem pela qualidade da produção científica ou podem gerar o chamado produtivismo; ou tornam os dois fenômenos, a produtividade e o produtivismo, indiscerniveis. Efetivamente, o que dizem os números quando apontam os mais produtivos, as revistas mais qualificadas, os autores mais citados? $\bigcirc$ estímulo ao publicar ou perecer gera artigos que, muitas vezes, não se dedicam a entender, a partir de uma análise qualitativa, porque há os mais produtivos, as mais qualificadas revistas, os autores mais citados?

Dentro do contexto dessa distorção que, muitas vezes, ocorre, há, hoje, o Ranking de Xangai. Esse ranking mundial de avaliação das Universidades produz, muitas vezes, a chamada Síndrome de Xangai. Publica-se mais do mesmo, em muitos casos. Eu me refiro, também, a algumas linhas do Manifesto de Leiden sobre métricas da pesquisa. São cinco autores de diferentes países que dizem o seguinte: cada vez mais se utilizam dados para gerenciar a pesquisa; as avaliações da pesquisa, que já foram individualizadas, solicitadas e realizadas por pares, atualmente são rotineiras e baseadas em métricas; a questão é que, agora, a avaliação é majoritariamente dependente de dados, em vez de juízo de valor. Por conseguinte, as métricas proliferaram, em geral bem intencionadas, nem sempre bem informadas e frequentemente mal aplicadas. Corremos o risco de prejudicar o sistema da ciência com as próprias ferramentas projetadas para melhorá-lo, uma vez 
que a avaliação é cada vez mais realizada por instituições sem o devido conhecimento sobre as boas práticas e sobre a interpretação adequada de indicadores. Os autores elencaram diversos outros indicadores que surgiram ao longo do tempo, no Manifesto de Leiden, e assinaram como cientometristas - vejam que é uma especialidade, eles são os que lidam com as métricas. Como cientistas sociais e gestores de pesquisa, temos observado com crescente apreensão a má aplicação generalizada de indicadores na avaliação do desempenho científico. Os exemplos a seguir são apenas alguns de inúmeros casos.

Em todo o mundo, as Universidades tornaram-se obcecadas com a sua posição nos rankings mundiais, a exemplo do Ranking de Xangai e da lista do Times Higher Education, apesar de essas listas serem baseadas no ponto de vista deles, em dados imprecisos e indicadores arbitrários. Os autores indicam, mais adiante, dez princípios para melhorar as práticas de avaliação da pesquisa.

Voltando à nossa realidade, como as Universidades têm lidado com esses fenômenos no Brasil? Todas essas questões estão mais claramente visiveis nas ciências que integram a outrora denominada Big Science. $\bigcirc$ que dizer das chamadas humanidades? Práticas de pesquisa específicas são, de certa forma, ignoradas no sistema de avaliação da ciência. Historiadores do mundo inteiro se ressentiram desses critérios que priorizam a publicação de artigos, já que suas práticas são e eram voltadas para a produção de livros, capítulos de livros, traduções com resultados mais consolidados. Hoje, o quadro já está mudando por força da absorção de critérios internacionais pela ciência brasileira. $\bigcirc$ que isso traz como consequências, afinal de contas, publicar ou perecer? Revistas novas ou relativamente novas, muitas das quais ainda sem avaliação do sistema Qualis da CAPES ou com avaliação baixa, acabam padecendo da doença de "um, dois, três". Ou seja, morrem no nascedouro, além da questão do conteúdo e da qualidade científica, seja porque não tiveram apoio institucional, seja porque não são procuradas por pesquisadores e alunos da Pós, que priorizarão as revistas que têm melhor posição no ranking. Inclusive, aprenderam com seus mestres. Quanto esforço se perde nesses caminhos? Quantos talentos perdidos são conhecidos?

A internacionalização da pesquisa é um outro item, critério hoje com peso para definir qualidade. Isso pode perder de vista prioridades locais que aguardam recursos e oportunidades para produzir novos

\section{0}

REV. TULHA, RIBEIRÃO PRETO, v. 7, n. 1 pp. 236-392, jan.-jun. 2021 
conhecimentos? E em relação às artes? Em relação à Filosofia? Como medir produção nesse campo com os mesmos instrumentos utilizados para a ciência de ponta e definidos por ela? Uma tradução de um texto em grego antigo, que leva, às vezes, anos para ser realizada, pode competir com artigos publicados em periódicos por pesquisadores dessas outras áreas do conhecimento, sobretudo as mais consolidadas? $\mathrm{O}$ que isso gera, inclusive, em termos de financiamento de pesquisa? E as oportunidades que se perdem de forma irreversivel? A priorização de temas de pesquisa obedece a uma política científica, muitas vezes, pouco conhecida dos pesquisadores: as políticas implícitas. Alguns campos do conhecimento são desvalorizados em detrimento de outras disciplinas, áreas que fazem parcerias com a indústria, por exemplo, e que geram lucros.

Esse seminário constitui uma oportunidade para indicar a necessidade de mudança de mentalidade no campo da pesquisa científica, tecnológica e inovadora, talvez uma espécie de virada conceitual e hermenêutica. Essa virada seria um novo ponto de partida para rediscutir o que, de fato, seria uma ciência comprometida com a sociedade, sem imitar tendências de países que já resolveram boa parte de suas mazelas sociais ou que têm suas próprias prioridades, senão focalizar as lentes investigativas em patamares condizentes com a realidade nacional de cada país, considerando a identidade e a cultura, vis-à-vis a sua trajetória histórica, não como propostas engessadas ou essencialistas, mas como uma plataforma que faça avançar a construção de saberes na sua singularidade. Seria uma espécie de mudança de paradigma na concepção da estrutura da ciência, tal como é concebida hoje. Talvez ainda seja necessário discutir concepções de tempo bem diversas, não aquela linear e homogênea, newtoniana, típica da retórica do Estado, que promove sua própria hegemonia, mas uma outra que considere o tempo da experiência, o tempo vivido, a intuição, a memória, a arte, a vida, enfim.

\section{4) Prof. Dr. Alexandre da Silva Costa (UFF)}

Por uma série de circunstâncias do pensamento contemporâneo, eu fui sentindo historicamente, durante o meu percurso acadêmico de formação, História e Filosofia, uma necessidade de me dedicar aos textos 
antigos, ao legado filosófico, poético, artístico de uma determinada tradição, na medida de poder avaliá-la e reconhecê-la também como impacto no nosso presente, digamos assim, nas espécies de confecção de uma presença que é trans-histórica. Portanto, ela exige necessariamente um diálogo com a História e a sua contínua construção e reconstrução.

Foi, de fato, uma coincidência feliz a presença da Profa. Icléia, que trabalha também com o conceito de memória. É importante lembrar, em se tratando dessa conexão, que os poemas de fundação da tradição ocidental - que é a llíada e, da mesma forma, a Odisseia -, assim como toda a épica grega, são obras das musas, divindades da memória. Logo, toda a cultura, que vem de "cultivo", inclusive, é um culto da memória. Investir, portanto, na memória, na sua construção, é resistir contra o esvaziamento, contra o esquecimento, contra o recalque, ou seja, aquilo que, sem, perde-se qualquer tipo de referência.

Concordo com a Profa. Icléia, que, dadas a dimensão e a magnitude do problema que o encontro evoca, este é um passo inicial - a princípio, talvez uma troca de ideias - que nos permita chegar a um consenso ou mais do que um consenso, a uma atitude conjunta.

Quando nós pensamos a Universidade, falamos, necessariamente, de política pública, o que não quer dizer que nós não possamos nem devamos instaurar uma reflexão acerca das áreas do saber ou campos do saber, acerca da nomenclatura terminológica das ciências por via epistemológica. Mas o que significa Epistemologia? Desenraizamento? Acircunstancialização? Infelizmente, temos sido muito afetados por essa acircunstancialização, por essa falta de enraizamento, que, por sua vez, é um sintoma de uma determinada cultura da objetividade, que marca a academia literalmente moderna, a partir do momento em que a objetividade foi, inclusive, inoculada por parte das ciências por interesse de quantificação de produção industrial.

A criação do conhecimento viria justamente do grego poíesis, a capacidade inventiva, engenhosa (aliás, daí vem o nome engenharia) do humano, e não a sua produtividade. Refiro-me a esse sintoma da produtividade e não da criatividade, que é um dos elementos engenhosos comuns à diversidade das ciências. Logo, o sentido próprio de Universidade é que, portanto, na sua origem, não disfarça a sua pretensão universal, ou seja, por isso universitas vem justamente da experiência, que diz universo e que, por sua vez, o universo diz

\section{2}

REV. TULHA, RIBEIRÃO PRETO, v. 7, n. I pp. 236-392, jan.-jun. 2021 
a unidade do diverso. Uma das unidades dessa diversidade toda - qual diversidade? Do humano - é aquele que cria ciência e cria diversamente modos distintos do conhecimento da ciência.

Portanto, o que nos une como Universidade seria justamente a produção de conhecimento na medida em que a ciência é um distintivo de um éthos: o que há de fenômeno comum no humano. Há vários fenômenos comuns no humano, a despeito das várias e diversas formas da humanidade. Assim, um desses pontos comuns é justamente o conhecimento, a ciência. Logo, o termo éthos, em grego, curiosamente remete-nos à ideia original, bastante simples, de lugar. Ou seja, toda a origem da reflexão acerca do éthos é uma pergunta sobre o lugar do humano na natureza no qual está inserido e, portanto, sobre aquilo que poderia ser não apenas o seu característico; daí a extensão do éthos para questão do caráter. Qual caráter do lugar humano que o distingue de outras formas naturais de vida? Ou quais os caracteres desse lugar que faz o lugar do humano ser tão diverso, mas, ainda assim, ser especificamente esse humano e não outro domínio, não outro éthos?

Nós partilhamos - eu acho que isso incide fortemente na intuição que leva a nomear a Universidade como Universidade - de um lugar comum na experiência humana que é ter o conhecimento, ter o saber (ou o nome que nós preferirmos), não somente como um elo comum da humanidade, como um traço, uma característica do humano, mas o inevitável. Ou seja, seria ingênuo querer declarar guerra ao conhecimento na medida em que ele nos é inevitável. A reflexão sobre o éthos, na sua origem, contempla, portanto, aquilo que é inegociável, que não está na ordem do meu querer, do meu gostar, do ser mais ou menos como sou. É uma tarefa e uma reflexão de origem filosófica, que quer reconhecer que lugar é esse.

Assim, na medida em que esse lugar é reconhecido, favorece-se aquilo que potencializa esse conjunto de caracteres ou de experiências, que são necessariamente humanas. É nesse sentido muito inusitado - "necessariamente humanas" - que as ciências humanas sejam uma subdivisão no mundo das ciências, porque isso me dá a entender que as demais não são humanas, logo, elas estão fora do éthos. Elas são desumanizadas? Elas são desumanizantes?

Há relação com a "cultura da objetividade", que talvez parece ter imposto, aí sim a um determinado segmento científico, uma

\section{3}

REV. TULHA, RIBEIRÃO PRETO, v. 7, n. 1 pp. 236-392, jan.-jun. 2021 
desumanização, como se não fossem humanos produzindo esse saber. Há toda uma doutrinação, uma inclinação muito ingênua de que há um conhecimento em si, uma realidade em si, e que aquele que produz conhecimento não tem nenhuma mão no conhecimento produzido, afinal ele é neutro, objetivo. Isso não se sustenta, nem querendo muito, como reflexão teórica a respeito das ciências do conhecimento. $O$ conhecimento humano e humanizado é totalmente tingido das nossas impressões digitais (a que farsa, portanto, obedecemos). Ainda insistimos numa objetivação de um certo dito conhecimento objetivo científico, ou que tenta associar ciência a essa objetividade.

Tendo cedido historicamente demais a isso, a Universidade trai o seu sentido basal, que é reconhecer a diversidade de conhecimento de cada área, reconhecer que são éthos específicos de criação de saber. Mas sem isso, há desunião. Universidade, ou seja, universo, também é união. A cultura da objetividade nos desuniu profundamente, no sentido em que há pouco diálogo: fala-se muito em interdisciplinaridade e realiza-se muito pouco. $\bigcirc$ que se vê como política pública e como política acadêmica formal, apesar dos louváveis gestos em contrário, é uma política de segmentação desses saberes e que, portanto, somente ratifica o afastamento ou mesmo o impedimento da possibilidade de diálogo. Por isso, é bem interessante ter uma oportunidade como essa, de estarmos falando, no melhor sentido, de diferenças e até de desigualdade das experiências com relação aos campos vários do saber, mas que redundou numa segmentação dessas partes e em políticas universitárias que hierarquizam esses campos naquilo que é linguagem predominante do nosso momento histórico, pelo menos a partir do século XVII, XVIII, que é justamente o que eu chamei de sintoma, a produção.

A produção tem a ver com a capacidade de produzir bens de consumo. Por isso, é necessário, é urgente que a Universidade reconheça o quanto ela é e vem sendo subserviente. Ela não tem ou tem muito pouca autonomia com relação, embora seja um universo, a um universo que "está lá fora, mas está em cheio aqui dentro". Nessas políticas de investimento acadêmico, são mais bem contemplados - e por isso vão ganhar maior status científico - aqueles que atendem à produção de necessidades de bens de consumo. É claro que, na sua experiência como cientista, talvez isso não interfira. Mas um cientista é financiado pela CAPES porque sua pesquisa pode resultar em aplicação na ordem dos bens de consumo. Já a reflexão filosófica, pelo contrário,

\section{4}

REV. TULHA, RIBEIRÃO PRETO, v. 7, n. I pp. 236-392, jan.-jun. 2021 
vai ser amaldiçoada, porque "essa gente" fica falando contra o bom funcionamento da máquina - porque a máquina está completamente interessada no êxito da produção. Produzir reflexão não apenas tem um outro tempo de dilatação e de sedimentação dos seus saberes, como além de tudo impõe certas dificuldades a essa locomotiva. Quem vai me financiar? Ninguém. Esse é um problema urgente. Eu acho que, em alguma medida ou em larga escala, é isso o sintoma.

Eu percebo que toda ciência é necessariamente humana. A pergunta é: por que justamente as ciências humanas e as suas áreas talvez mais próximas, como as próprias artes a princípio, caíram nesse lugar de pouco investimento, de pouca relevância de reconhecimento nas políticas públicas acadêmicas para a Universidade ou, no caso do Brasil, pelo menos atualmente, mais contra a Universidade do que para a Universidade? Eu acho muito grave nós estarmos aqui e não nos lembrarmos do nosso universo, do universo que nos rodeia e que nos invade, como bem lembrou a Profa. Icléia. Não somente, neste momento, há uma consulta pública do Senado brasileiro para a extinção dos cursos de humanidades nas Universidades Públicas. Isso está em aberto e há um projeto para tal, senão não haveria consultoria pública. $\bigcirc$ argumento é: "esses cursos são muito baratos e faculdades particulares poderiam assumir isso". Isso é uma farsa, porque faculdade particular quer ganhar dinheiro; é uma empresa e não vai ganhar dinheiro com que não produz bens de consumo.

Há outra grande farsa, que está no texto do projeto: se são cursos baratos, qualquer cidadão poderia pagar para se formar nesse curso (cursos que não prometem emprego, cursos que, a princípio, talvez fora do mundo justamente da ciência, não prometem emprego). Além disso, qualquer cidadão brasileiro é tão abastado para pagar um curso numa Universidade ou numa faculdade particular? Então são questões absolutamente graves, justo num momento em que, além dessa consulta pública, a disciplina de Filosofia foi retirada do Ensino Médio, na última quinta-feira em nível nacional, repetindo a reforma de 1965 após o Golpe militar. $\bigcirc$ Brasil repete os seus mesmos gestos de forma quase histriônica.

quanto isso diz do nosso momento, em termos em nível simbólico? $\bigcirc$ que significa retirar a Filosofia do Ensino Médio nacional, depois de ter voltado apenas há nove anos? Por que ela foi retirada em 65 para voltar há nove anos? Durou nove anos, retiraram de novo. É preciso que

\section{5}

REV. TULHA, RIBEIRÃO PRETO, v. 7, n. I pp. 236-392, jan.-jun. 2021 
se digira isso nesse plano. Faço parte de um departamento, de uma universidade, portanto de uma política do conhecimento em que nós lutamos muito, aproveitando aquela nova realidade de inclusão da Filosofia nas escolas, para termos cursos especializados em Licenciatura. Passar isso na CAPES foi um sufoco. Agora eu tenho turmas cheias, felizmente, para as quais eu digo: vocês não têm possibilidade de emprego. Eu passo por isso todos os dias: eu vou dar aula num lugar que quem está sentado à minha frente ou é maluco ou é herói, ou não tem o que fazer. Formalizaram que ele não pode ter emprego. Esse poder é o poder de uma força econômica e cultural, o que eu estou chamando de uma sociedade para bens de consumo, que captura completamente a Universidade e mostra sua devastação mais violenta, como esses gestos fazem ver.

Os mais recentes episódios são os mais graves, de maior magnitude, que chegam ao extremo de uma identidade que temos não reconhecido. Justamente por atuarmos em outros campos do saber não tão afetados, sequer a reconhecemos, já que não nos acossa tanto. A questão das notas, de como se faz a qualificação, é, na verdade, quantificação, e não qualificação. Logo, outro paradoxo terrivel: toda uma cultura acadêmica é analítica, mas que não faz análise de nada a respeito da sua produção. Ela não reconhece a diversidade da unidade da ciência, que haja protagonismos nesse mundo científico que obriga outros setores de ciência a ser coadjuvante, que é uma das formas mais terriveis de fechar esses lugares: não ter orçamento, não ter financiamento, não ter bolsa, justamente porque não há produção desejada. Por conseguinte, ficamos nessa ilusão de que a minha pesquisa está sendo contemplada pela minha excelência, sim em parte, mas ela é instrumentalizada pelo Estado, ou mais do que pelo Estado, pelo mercado, vamos falar o termo claro.

Não se criticam os cientistas ou quem produza ou crie esse conhecimento. Mas, muitas vezes, o favorecimento que ele recebe tem a ver com uma dimensão que, se não for uma teoria crítica, se não for, talvez, a reflexão filosófica, não forem os sociólogos, historiadores e outros campos análogos, dificilmente ela vai ser feita, dificilmente haverá a criação de uma leitura disso, que é o universo que nos circunda. Para repetir o termo que utilizei, captura-nos mesmo quando nós não reconhecemos ou, eu diria mais radicalmente, tanto mais nos captura quanto mais nós não reconhecemos.

\section{6}

REV. TULHA, RIBEIRÃO PRETO, v. 7, n. I pp. 236-392, jan.-jun. 2021 
Há toda uma cultura da CAPES, do CNPa, de quantificação, dos currículos, das provas. Para nós, é muito difícil um paper valer mais do que um livro. A nossa experiência é completamente outra em relação a isso. Mas há, ao que parece, uma tiranização do padrão de notificação pelas ciências médico-biológicas. Não há nada contra o modo como se produz conhecimento nessas áreas, que, dependentes da observação, do experimento laboratorial, no caso da medicina, da própria urgência, elas são marcadas por um tipo de atualização e velocidade completamente estranho ao que é a lentidão das Artes, da Filosofia, das Letras, por exemplo. Chamar lentidão é justamente o modo como opera um determinado pensamento para esse tipo de criação de conhecimento. Assim, estão conseguindo perverter completamente uma tradição milenar, porque, afinal de contas, o meu orientando e a minha orientanda não querem ficar desempregados. Eles vão criando o cacoete de como funciona para passar no concurso, por consequência, ninguém mais escreve livro, porque se compara com o médico, que escreve paper com oito pessoas juntas. Isso é de uma violência! Entenderei que esse aluno e essa aluna que querem ingressar aqui começam a ser servis, porque eles também têm que comer, eles também têm que trabalhar. Descaracteriza-se, por completo, um ofício tanto mais antigo do que tantas outras formas de produção de conhecimento, que nos tiranizam, dada a nossa reflexão. Há uma falta de coesão a partir da diversidade. Por isso, a Universidade, há muito, não é universidade. Desejam-se campos de isolamento, com nenhuma conversa, em que o papo da interdisciplinaridade se torna uma balela, a despeito das louváveis exceções e dos louváveis esforços.

Portanto, ao comentar que ciência é não humana, justamente faço o elogio da humanidade da ciência e, ao mesmo tempo, protesto contra o isolamento das ciências humanas. Não gostaria em ocasiões futuras, como também não hoje, pensar isso em nivel meramente epistemológico, ou gostaria de pensar nisso como uma nova categoria epistemológica, não a da objetividade de uma epistemologia, mas a verdadeira epistemologia, que é saber considerar e reconhecer aquilo que interfere na própria criação do conhecimento. Como espero ter tocado em alguns pontos delicados, são muitos esses elementos em que nós não somos autônomos, pelo contrário, nós somos plenamente condicionados por coisas e ordens que nos superam diante de nossa impotência. Justamente porque somos condicionados, é quase um acidente que certas áreas são beneficiadas para além e para aquém das nossas vontades; bem como outras são acidentalmente

\section{7}

REV. TULHA, RIBEIRÃO PRETO, v. 7, n. I pp. 236-392, jan.jun. 2021 
segregadas, marginalizadas e conduzidas no momento atual do país. Há, nisso, uma especificidade brasileira, apesar de concordar que a crise seja, talvez, um fenômeno mundial. Por conseguinte, as áreas são levadas à asfixia, que é isso que nós estamos presenciando, a meu ver, muito particularmente no Brasil.

\section{Discussões}

5) Prof. Dr. Tito José Bonagamba (IFSC-USP)

Eu tenho vivido a Universidade de São Paulo talvez de uma forma diferente da maioria das pessoas. Eu vejo a Universidade como um ambiente de um universo, em que nós temos a questão da multi e interdisciplinaridade, mas que, às vezes, esse discurso se limita à voz e não à atuação. Nesse sentido, o meu discurso será não de cima para baixo, mas de baixo para cima, olhando o indivíduo ou a Unidade de Ensino e Pesquisa a que ele pertence. $\bigcirc$ individuo da Universidade será plenamente acadêmico ou acadêmico universal quando ele tiver a percepção de que ele terá um desenvolvimento pleno somente se ele conhecer as outras áreas do conhecimento. Ao conhecê-las, obviamente ele reconhece sua competência e seu valor. Por consequência, ao conduzir a redação de projetos de grande porte, certamente ele saberá que, em se tratando, por exemplo, de energia com álcool de segunda geração, precisa-se "bater à porta" da FFLCH para saber como eles conhecem o ciclo do açúcar na História do país. Eu tenho que "bater à porta" da ESALQ para saber como é a questão da produção do açúcar. Tenho que falar com os químicos para saber como eu vou tratar a fibra de celulose, para que ela possa ser transformada em açúcar e, depois, em álcool.

Assim, o indivíduo da Universidade de São Paulo, enquanto ele não tiver esse papel, essa nossa discussão será inútil, porque ela não existe no elemento fundamental da Universidade, que é a mentalidade de construção da Universidade, seja do Rio de Janeiro, seja de São Paulo ou mesmo de Bolonha, onde for. Logo, nós temos que trabalhar na formação dos nossos alunos e também na rediscussão, como neste momento, a fim de que o agente da Universidade de São Paulo, o professor e o aluno possam entender melhor o ambiente em que ele habita. Não se pode ser um acadêmico e não entender o valor de

\section{8}

REV. TULHA, RIBEIRÃO PRETO, v. 7, n. I pp. 236-392, jan.jun. 2021 
todas as Unidades. Embora eu seja físico, eu diria, hoje, que as pessoas com quem eu mais troco mensagens são pessoas da Música, são pessoas da Faculdade de Economia e Administração e da Escola de Educação Física. Eu me sinto como um personagem de valor dentro da Universidade de São Paulo porque eu procuro conhecer e, nesse ato, eu reconheço as demandas de um Departamento de Música.

Enquanto o Prof. Ignacio e eu estávamos na Pós-Graduação, rediscutíamos os programas de Pós-Graduação da Universidade de São Paulo. Eu escolhi, corajosamente, rever os programas de avaliação, os critérios de avaliação da FFLCH. Foi uma experiência fantástica, porque, ao passar por esse momento, eu entendo o que é a produção científica, quais são os módulos de produção que esses setores têm. Então, no momento em que se fala de Universidade, interdisciplinaridade e multi, significa que nós todos temos que ser assim, e não ter o discurso de que a Universidade tem que ser assim.

Além disso, saindo do ambiente da pessoa Universidade, de que nós temos que trabalhar para ter a transformação, não interessa a classificação. Essa reclassificação se torna desnecessária porque o conceito da classificação está na pessoa e no valor que ela dá a cada tipo de pesquisa que tem, se é escrevendo livro, se é escrevendo artigos, se é regendo, escrevendo uma música por uma partitura etc. Tudo isso tem valor; aliás, todos os setores escrevem livros. Eu sou físico, eu já escrevi um livro. Quando me perguntam se eu gosto mais daquela revista fantástica em que todo mundo me citou ou o livro, eu tenho mais orgulho do meu livro. Então, nós temos coincidências, ou seja, a nossa batalha, na hora em que nós nos conhecemos, será única, que é o conhecimento por si só.

Saindo do indivíduo, vou para as Unidades. $\bigcirc$ que se diz quando se pensam multi e interdisciplinaridade dentro de uma Universidade? Seria um Instituto de Química ter dentro dele pessoas que entendem de física, que entendem da economia, de certos setores produtivos e assim por diante. Quando fazemos esse discurso e visitamos cada Unidade, vemos que a maioria delas não contrata pessoas de outras áreas de conhecimento. A FFLCH tem um, talvez dois físicos, a Química não contrata físicos, a Engenharia não reconhece. Então, nós vivemos essa questão, ou seja, o de baixo para cima não existe. Eu entendo que, enquanto nós não trabalharmos como indivíduos ou como indivíduos que pertencem a Unidades de Ensino e Pesquisa, nesse princípio, a discussão

\section{9}

REV. TULHA, RIBEIRÃO PRETO, v. 7, n. I pp. 236-392, jan.jun. 2021 
de cima para baixo não acontecerá, porque ela não vai encontrar uma ponte de conexão. Ou nós nos reconheçamos ou permaneceremos na situação que antecede essa discussão que nós tivemos.

É fundamental, por exemplo, que as Unidades de Ensino e Pesquisa da Universidade tenham, em seus corpos docentes, uma mescla de pessoas com competências distintas. Eu dou exemplo da minha Unidade, - Instituto de Física de São Carlos, que, dentro do seu quadro docente, $25 \%$ não são físicos. São eles que fazem com que possamos fazer um pouco de diferença na área da Medicina, Microbiologia, Química medicinal, e assim por diante. Dentro dos nossos colóquios, dentro das nossas discussões fundamentais, todas as áreas de conhecimento são fundamentais.

A Universidade de São Paulo pede para que cada departamento escreva seu projeto acadêmico. Isso é fundamental porque, ao escrever um projeto acadêmico, associa-se a um tipo de produtividade esperada, que seu docente tenha. Nós estaríamos resgatando o valor de cada área de pesquisa que existe na Universidade de São Paulo. Isso acontece na CAPES e em alguns setores também. Quando nós olhamos as áreas mais negligenciadas, às vezes são elas que não apresentaram as suas próprias características para a autoavaliação. Alguns setores são organizados: a Física é organizada, ela sabe o que ela cobra e respondemos daquele modo. Mas a arquitetura talvez precise dessa reflexão, que tem problema na CAPES.

\section{6) Prof. Dr. Diego Antonio Falceta Gonçalves (EACH-USP)}

Costaria de comentar um pouquinho sobre a minha experiência na infância, adolescência, chegando à Universidade: foi uma grande decepção a chegada à Universidade, na verdade. A necessidade de escolher a área que eu seguiria em minha carreira profissional e o exame FUVEST em 97 geraram-me um problema existencial grande, que era decidir entre História, Física, Medicina, Biologia e Ceografia: eram todas essas áreas que eu amava. Eu tinha vontade de trabalhar com tudo isso: descobrir e criar conhecimento era o objetivo; eu não tinha objetivo de trabalhar numa determinada área. Na infância, eu fui seduzido pela astronomia, uma questão familiar. Fui levado para dentro 
da ciência, observava o céu, aquele romantismo todo; e isso me trouxe para a criação do conhecimento. Eu gostaria de ter trabalhado com todos os conhecimentos, mas me foi colocado um cabresto no momento em que eu me inscrevi no vestibular.

Quando eu entro no Instituto de Física daqui de São Paulo, essas paredes são mais sólidas do que eu imaginava: o trânsito entre os institutos era praticamente nulo por uma questão burocrática, em que os créditos de disciplinas não eram válidos. Eu não poderia, portanto, nem transitar como estudante entre os diferentes institutos, porque aquilo me atrapalharia na graduação. Eu fui obrigado, logo, a viver isolado dentro de um instituto, mesmo querendo transitar pela Universidade. A Universidade não me permitiu isso. Depois, saí do Instituto de Física, fui para a Astronomia para fazer Doutorado. Na Pós-Graduação, já se apresentam as métricas de produção, as necessidades a que o programa de Pós-Graduação tem que atender para manter a nota sete na CAPES, que é o caso do IAC aqui na USP. Eu também não pude transitar entre outros programas de Pós-Graduação, mesmo até fazer uma segunda graduação simultaneamente, porque eu tinha que produzir. Eu tinha que ser um aluno produtivo dentro da Pós-Graduação. Eu percebo, hoje, que isso não foi bom.

Eu tenho exemplos de outras instituições fora do Brasil que funcionam de forma diferente. Eu vejo a realidade dos egressos dessas instituições bem diferente. Embora eles sejam profissionalmente equivalentes, eles são humanamente diferentes, porque eles se apropriaram do conhecimento de forma diferente, sem as barreiras com que a Universidade funciona, como ela está estabelecida, principalmente na Universidade de São Paulo.

Quando o Prof. Rubens traz esse questionamento de rediscutir a organização do conhecimento aqui na Universidade, eu me lembrei de tudo isso. Eu fui seduzido a participar disso não pelo meu conhecimento, porque, no fundo, eu sou especialista numa pequena área, não entendo nada das outras áreas pela minha formação. Mas eu tenho desejo que isso se transforme para o futuro, para uma futura geração.

A Astronomia, talvez ainda mais do que a Filosofia, não tem serventia para o mercado. A Astronomia é parte da Física, mas a Astronomia é considerada de altíssima produtividade, de altíssimo impacto, mas de mercado nulo, absolutamente nulo. Talvez nem tudo 
seja controlado pelo mercado, mas talvez pelo próprio coletivo, em que a perversidade da segregação das áreas dentro da Universidade talvez seja criada pela própria Universidade, e não pelo mercado, não pela sociedade, que, no Brasil, é alheia à própria Universidade. Não se sabe o que acontece aqui dentro. A Universidade não faz nenhum esforço de também ocupar seu espaço dentro da sociedade.

Eu tenho prazer de estar em uma área que ela é supra crises sociais, supra crises humanas, incluindo crises financeiras, porque ela é quase que uma intersecção entre a Filosofia Clássica e a Física Contemporânea. Ela é uma área bem interessante, e eu tenho um prazer enorme de estar nela hoje. Mas eu gostaria, também, de visitar outras áreas ainda.

$\bigcirc$ Prof. Tito acaba de mencionar alguns exemplos de como os institutos funcionam, mas para o desenvolvimento do conhecimento, para a construção de conhecimento, eles são positivos? De um ponto de vista de gestão de pessoas, é importante. Por que eu digo isso? Porque eu estou numa Unidade da Universidade de São Paulo que é a Escola de Artes, Ciências e Humanidades - vejam o nome - sem departamento. De todos os adjetivos que eu poderia utilizar para esse tipo de organização, o mais leve é "uma bagunça", porque, no meio de todo o processo de gestão da Universidade, a avaliação é parte disso, e não se consegue avaliar aquilo que não se conhece. Então, a organização de áreas é importante para a gestão, seja de recursos humanos, seja de recursos financeiros, mas talvez não seja positiva para a própria construção do conhecimento. Logo, precisamos reconstruir a instituição, organizando-a. Afinal, para que o conhecimento está sendo dividido? Para que a organização existe? É para a gestão ou é para a própria construção do conhecimento? Para a construção do conhecimento, eu imagino que o modelo ideal seria nenhum docente ser vinculado a departamento algum. Nós somos docentes da Universidade e nós transitamos entre as áreas de acordo com os interesses naquele instante. Seria o ideal, porque o processo avaliativo torna-se local, pontual no tempo, e não geográfico, de acordo com os muros entre os quais o pesquisador se insere. Esse seria um modelo interessante. Eu não sei, mas é uma provocação para a discussão se seria possível separar essa discussão entre o objetivo gestão e o objetivo produção do conhecimento. 


\section{7) Prof. Dr. Alexandre da Silva Costa (UFF)}

Eu concordo inteiramente com vocês. Nesse momento, estou fazendo uma autocrítica: eu tive o cuidado em dizer: "olha, são provocações no bom sentido"; em nenhum momento falei justamente em defesa tanto da unidade quanto da diversidade. São dois momentos diferentes e que, portanto, a especialização tem o seu lugar. Nosso trabalho é a especialização, o meu também. Qual o elemento comum, qual o elemento da diferença? Não deixar ceder aquilo que tem sido uma política desigual em termos de recursos e que o mercado não invada tudo ainda. A maior prova disso é justamente o curso de Filosofia ainda. Eu não disse, em nenhum momento, que o mercado domina completamente. A nossa resistência é que isso ainda exista, mas nós temos dados do seu sucateamento efetivo, do seu desaparecimento progressivo. Isso não pode ser, no meu ver, não dito.

Eu fiz vestibular para Astronomia também, sei que ela não tem mercado, aliás é um dos argumentos que eu uso quando não sei de onde essas pessoas ficam falando do modelo dos Estados Unidos como Universidade completamente privada - que não é - porque telescópio nenhuma empresa banca. É uma ilusão o que se propagandeia no Brasil a respeito de uma Universidade de Estado forte e maciço, a Universidade estado-unidense. Sem o Estado Americano forte em determinadas áreas, eles não seriam a potência que são nessas mesmas áreas. Então eu vejo muita simplificação, e eu gostaria de não ter me expressado tão mal a ponto de ser simplificado. Em nenhum momento, eu falei contra a interdisciplinaridade. Estou falando contra não haver ela para além dos nossos esforços louváveis, ou não haver no quilate em que ela deveria existir, o que nos protegeria.

É bom saber do Instituto de Ciências e Artes, como a UFMC fez um movimento também muito parecido, que uniu várias partes que estão divididas em departamentos, virou um grande instituto, confluindo determinadas áreas das Ciências Sociais, Humanas e acho que o Direito entrou também, e outros setores, não sei qual a extensão, mas eu sei que a UFMC fez uma reforma grande nesse sentido. Então, todas essas iniciativas são muito louváveis.

Agora, como fica a relação do particular com o geral, com a diversidade, com a unidade, com aquilo que é comum e com aquilo que

\section{3}

REV. TULHA, RIBEIRÃO PRETO, v. 7, n. I pp. 236-392, jan.-jun. 2021 
nos fortalece e mantém um sentido próprio de Universidade e que tem um mercado em que é possivel manter-se em algum grau? A pergunta é: que grau? Em algum grau, conseguimos resistir; em outro grau, sem nos apercebermos, vamos cedendo. Tentei ter a delicadeza em dizer que, na experiência propriamente científica ou cognitiva, a respeito da criação de conhecimento, eu não tenho nada a dizer nem contra nem a favor. Acho genuíno que seja do éthos humano a poesia, a poíesis em grego, a invenção, a criação, ou seja, a poesia do conhecimento e da ciência. Se falamos em qualificar, em tornar multidisciplinar - uma palavra que eu prefiro, à interdisciplinar -, não tome isso como pessoal.

Um dos grandes inimigos é o conceito de indivíduo. Falou-se em isolamento, falou-se muito em indivíduo. $\bigcirc$ indivíduo vem de indivisivel, que, em grego, quer dizer átomo. Historicamente, as pessoas são indivíduos a partir da revolução científica do século XVII, quando uma determinada física newtoniana tomou conta da cultura inteira: eu vim da Física. Está aí uma possível desumanização da Física como ciência. Ela se atomiza e espraia uma cultura do átomo que, como nós sabemos, estudamos partículas subatômica. A cultura do átomo não se sustenta nem no sentido da Física, porque nem o átomo é indivisível. Logo, é uma contradição em termos, e que isso tenha se encaminhado para a cultura, para as línguas. A pergunta é, desde quando as pessoas, os humanos são átomos e átomos indivisíveis? Isso não é uma delicadeza. Isso tornou os humanos pessoas encapsuladas nos seus pequenos mundos atômicos indivisiveis, e elas se individualizaram. Fica esse "Deus nos acuda", como é o dito popular, e se é popular é muito popular, "farinha pouca, meu pirão primeiro". Assim se pronunciam os átomos.

É preciso urgente restaurar o conceito de pessoa, a superação do indivíduo, porque, sem a superação de indivíduo, não existe multidisciplinaridade. Para mim, o indivíduo é um conceito falido; entretanto uma máquina, exatamente isso, vem do conceito de homem máquina, muitíssimo complicado. Isso demanda uma reconstrução de memória e de humanidade, que veio de uma determinada ciência que se consolida historicamente. Um projeto que começa hoje demora alguns séculos para desfazer tamanha identidade. Portanto, quando se fala em recuperar certos sentidos de Universidade e recriá-los, porque não se resgata o passado, inventa-se o presente.

Eu acho que essas experiências têm que ser evocadas da memória. Elas têm que ser enfrentadas com a delicadeza que elas merecem,

\section{4}

REV. TULHA, RIBEIRÃO PRETO, v. 7, n. I pp. 236-392, jan.-jun. 2021 
mas também com o afinco que elas demandam. Caso contrário, vamos permanecer no mesmo lugar: o lugar dos indivíduos separados, que não dialogam. Fala-se muito em diálogo, e diálogo é difícil de ter. Por isso, eu tenho essa delicadeza "olha, não é nada contra a pessoa", mas diálogo é invasão, senão não é diálogo. Invasão. Estou com os gregos antigos, é preciso saber o que é um diálogo. Diálogo é guerra, e se interessa o diálogo, temos que saber ser invadido, porque isso é luta. Justamente como eu tento superar o indivíduo, nada disso é pessoal, mas isso é necessário, senão não temos diálogo.

\section{8) Prof. Dr. Thomás Augusto Santoro Haddad (EACH)}

Eu já fiz parte de um continente dessa cartografia que é a Física. Não é apenas uma cartografia espacial, em um sentindo muito simplificado da distância entre as áreas, mas guarda representações de imagens que nós temos sobre uma certa hierarquia de centros de poder. Eu já estive em um continente que é considerado muito poderoso, o da Física. Passei para um outro continente que é o da História, da História da Ciência, mais especificamente. Fui fazer faculdade de novo, fui passar por toda a via crucis, o cursus honorum. Estou dizendo isso apenas para tentar, antes das coisas mais substantivas que eu vou falar, dizer que eu considero ter uma considerável experiência em estar nessas partes, às vezes até como o antípoda, consideradas antípodas dessa cartografia do conhecimento.

Dito isso, eu preciso fazer algumas considerações que não têm o objetivo de uma polêmica vazia, nada desse tipo, especialmente porque eu sou um defensor ardoroso das Humanidades, da sua presença nas Universidades. Eu resolvi transformar aquilo que parecia que seria a minha vida profissional em uma vida nas Humanidades, na História, mas eu acho que, em primeiro lugar, temos que ter um pouco mais de ceticismo em relação à ideia das hierarquias e de quem tem o poder no campo acadêmico, vamos dizer assim.

Eu acho que também temos que considerar que há uma notável autonomia desse campo, pois ele define, muitas vezes, as suas próprias regras, mesmo que ele se organize analogicamente como um mercado. Mas ele tem mecanismos de se proteger daquilo que é o mercado no

\section{5}

REV. TULHA, RIBEIRÃO PRETO, v. 7, n. I pp. 236-392, jan.-jun. 2021 
discurso mais usual, que nós empregamos, que está na imprensa etc. Eu acho que esse mercado, que é um mercado de bens simbólicos, muitas vezes precisa gerar ideias de diferenças ou de hierarquias até para se sustentar. Essas ideias não se conjugam muito bem com alguns dados com os quais temos que lidar e precisam ser confrontados.

Considerando o que a Profa. Icléia e o Prof. Alexandre mencionaram, sobre a questão dos rankings, por exemplo, eu acho que eles são uma grande porcaria. Posso dizer isso sem nenhum problema. Costei muito do Manifesto de Leiden quando foi publicado e de outras questões que vão ainda além na crítica. Mas na Universidade de São Paulo, a preocupação com os rankings estourou. Ela se tornou a linha de frente do nosso cotidiano, quando essa Universidade era liderada por um Jurista e não por um Bioquímico, por um Físico, por um Astrofísico. $\bigcirc$ sistema de Pós-Graduação, que está para mudar, é resultado de um acúmulo não contínuo, mas um acúmulo de algumas décadas, mas ele recebeu uma contribuição, a sua arquitetura atualmente visivel, uma contribuição fundamental, que foi dada por um Filósofo da Universidade de São Paulo, Prof. Renato Janine. Não foi dada essa contribuição novamente pelo Físico, pelo Químico, pelo Biotecnologista, pelo Agrônomo etc.

Eu sou editor de uma revista, uma das duas revistas de História da Ciência que tem aqui no Brasil. Eu acho o Qualis um negócio muito complicado, muito difícil em diversos aspectos. Frequentemente, nos nossos fóruns de Ciências Humanas, dos programas de Pós-Graduação em História e de outras áreas das Humanas, ouvimos: "puxa, como é perverso o Qualis" etc. Por outro lado, a ideia de um Qualis livros, fazendo uma espécie de uma mímeses do Qualis de periódicos, foi encampada com um enorme investimento de energia por áreas das Ciências Humanas, que não foram tentar mudar o sistema, mas foram tentar entrar no sistema, principalmente, a área de Educação. A área de Educação é uma das que têm o Qualis livros mais desenvolvido. Eu vou dizer apenas que a ideia não foi mudar o sistema, mas foi entrar nele também. Na área de História da CAPES, definiu-se que "x" artigos publicados em periódicos do Qualis do estrato superior valem o mesmo que um livro. Na área de História - eu não sei se é na chave do que o Prof. Alexandre falou sobre a captura ou se é uma servidão voluntária, ou ainda, se é se colocar numa posição de servidão que atende a uma função retórica de manutenção dessa cartografia - as pessoas querem sobreviver, ou se as pessoas querem florescer mais do que uma sobrevida. Mas na dinâmica desse campo acadêmico - com as suas

\section{6}

REV. TULHA, RIBEIRÃO PRETO, v. 7, n. I pp. 236-392, jan.-jun. 2021 
ithas e continentes e as suas aparentes centrais de poder, os países, as regiões marginais etc. -muitas vezes se consideram essas regiões marginais os locais centrais. Isso me faz pensar que estamos vivendo na Alemanha do século XIX, em que os Sociólogos, os Filósofos etc. estão tendo imensas brigas, "não, porque temos que nos espelhar nas Ciências Naturais, porque elas que são o exemplo disso ou daquilo". No entanto, como se sabe, quem mandava na Universidade alemã, os mandarins alemães, eram Teólogos, eram Historiadores, eram Juristas, eles não eram os Físicos, os Químicos, os Bioquímicos. Nas representações da época, eles eram considerados as faculdades secundárias em comparação com a nobre Faculdade de Teologia, com a Faculdade de Direito e com a Faculdade de Filosofia.

\section{9) Prof. Dr. Alexandre da Silva Costa (UFF)}

Há um sintoma que permanece no diálogo. Foi feita uma defesa; eu não acusei ninguém. A ideia é unir, não é separar. Eu entendo a sua defesa, mas isso mostra que se ouvem coisas que não estão na minha fala. "Eu venho da Física", por isso mesmo não mencionei a Física em nenhum momento. Eu sei o quanto que pesa falar de objetividade: "ah, está falando da gente". Ainda falei: ao que parece, pelo que me consta o padrão de avaliação especificamente com relação à coisa de quantificar periódico mais que valor de livro vem da Médica Biológica.

Estou sendo solidário, inclusive com o sintoma. Eu entendo o sintoma, mas, por favor, eu não falei isso. Portanto, também entenda o seu sintoma, porque é uma defesa desnecessária para essa conversa. Não aconteceu essa acusação. Ouça-se porque isso diz muito. Estou solidário à sua dor. Da mesma forma, eu não disse que, nas Humanas, é diferente. Impõe-se uma cultura, que eu também não sei de onde se origina, de uma determinada quantificação. Desde a Revolução Industrial, houve uma transformação do universo acadêmico universitário. Nessa mudança, passa o paradigma de a quantificação valer para todo mundo, inclusive para Teologia, para a Filosofia. Quando eu discuto com filósofos, a minha situação é de mesma dificuldade. Quando eu falo de tática de sobrevivência, não é só nas Humanas, é de todo mundo, porque esse é um modo de fazer. Entra-se na Universidade, ensina-se não apenas o que produzimos como conhecimento etc. Ensina-se um

\section{7}

REV. TULHA, RIBEIRÃO PRETO, v. 7, n. I pp. 236-392, jan.-jun. 2021 
certo modo de sobreviver nessa academia. É mais difícil ainda com o mercado, em relação à vida e à sobrevivência. Estamos falando de emprego, estamos falando de pagar a conta. Isso anestesia a reflexão, venha ela de um Físico, de um Matemático, de um Filósofo, de um Historiador, de um Jurista, porque há interesse. Sobreviver significa prosperar. Caímos num modus operandi que já é atávico. Por isso que é bom que se unam todas as forças, que, em cada lugar, perceba-se - que essa quantificação significa. Essa cultura da quantificação tem sido mortificante, justamente para a produção de ciência em qualquer área ou mais do que isso, mais do que da produção, da criação de conhecimento. Em suma, eu estou com vocês, e não contra.

\section{0)Prof. Dr. Fritz Cavalcante Huguenin (FFCLRP)}

Existe um relatório de 1828 de Yale, que afirma que, naquela época, a Universidade já estava preocupada com a formação dos seus alunos, porque, depois da revolução industrial, a formação dos alunos estava voltada para o mercado de trabalho. Estava se discutindo sobre a questão, a partir de uma visão mais sistêmica, para que o aluno, depois de formado, crie o alicerce e possa ser independente e "andar com as próprias pernas". Essa discussão parece ser um problema atual, mas, às vezes, é muito antiga. Sócrates já falava que a formação dele já não era a mesma de seu pai. São coisas que ocorrem, mas, na verdade, é uma questão que já vem antes.

Sobre a questão de produtividade, parecia que era a área de Ciências que estava voltada para o mercado trabalho, mas realmente não é. Mesmo na área de Ciências, para conseguir o financiamento, o pesquisador necessita provar que tem um horizonte de aplicação. Se for só o estudo fundamental, existe uma dificuldade a mais para isso; não que não tenha, mas o apelo diminui.

Sobre a questão da interação com as outras áreas, consideremse um Matemático, um Físico, um Químico, um Biólogo: quando aumenta a complexidade do sistema em análise, utiliza-se de uma forma operacionalizada o conhecimento que vem do Matemático, do Físico. Isso nos torna - talvez seja uma palavra forte - mais especialistas mediocres. Mas até que ponto nós podemos evitar isso? $\bigcirc$ problema

\section{8}

REV. TULHA, RIBEIRÃO PRETO, v. 7, n. I pp. 236-392, jan.-jun. 2021 
surge, também, de uma necessidade de mercado que nós não podemos

desprezar. É preciso ter um certo equilibrio: o conhecimento pelo conhecimento é extremamente relevante, o desenvolvimento econômico é importante, mas não podemos nos esquecer do desenvolvimento social, não podemos nos esquecer da arte e da música que nos leva ao desenvolvimento humano, ao desembrutecimento da alma. Enquanto se julga produtividade, deveria ser analisada a relevância do seu trabalho. Quando se analisa em termos de número, a qualidade é inversamente proporcional à quantidade.

\section{1)Prof. Dr. Alexandre da Silva Costa (UFF)}

Eu voltei de Berlim para o Brasil porque a situação da política pública acadêmica na Filosofia alemã ou na Filosofia, hoje, na Alemanha, na Humboldt, por exemplo, é a seguinte: um jovem pesquisador consegue desenvolver-se se apoiar a indústria farmacêutica. $\bigcirc$ grande tema para isso tem bolsa que não acaba mais - é enhancement. A biopolítica do Foucault foi parar aí. É uma perversão gritante.

Todo gênero antes chamado de ciência pura - pura porque é depurada - estaria em distinção da ciência aplicada, não em contradição. $\bigcirc$ investimento - esqueçamos as distinções das áreas - é em ciência aplicada, porque é aplicada a mercado, à indústria, a bens de consumo. Na Física, na Química, na Filosofia - o que for puro não joga. Darei um exemplo um pouco defasado: ninguém financiará uma pesquisa sobre pontes de hidrogênio. Mas se der uma bomba, então há negócio.

\section{2)Prof. Dr. Fritz Cavalcante Huguenin (FFCLRP)}

Há um exemplo muito interessante sobre o Hertz. Quando ele estava estudando sobre as ondas de rádio, perguntaram a ele o motivo do estudo. Ele disse que não havia aplicação nenhuma, senão comprovar as Leis de Maxwell e depois as ondas de rádio. 


\section{3)Prof. Dr. Ignacio Maria Poveda Velasco (FD, SC)}

Nós estamos aqui discutimos sobre a questão das grandes áreas do conhecimento. Embora o conhecimento seja amplo, em termos práticos, quando nós pensamos como estudiosos, como pesquisadores, nós temos que nos ater a algum conhecimento. Aqueles grandes pensadores, como Aristóteles, não existem mais. Além disso, o estado da ciência hoje é muito diferente do que era no passado, na época dos grandes sábios.

Nós podemos questionar sobre a questão da divisão das áreas de conhecimento na medida em que isso implica em avaliação. Essa definição de áreas se transforma em um espartilho, dentro do qual não nos sentimos à vontade. Por outro lado, quanto à questão da interdisciplinaridade ou multidisciplinaridade, o problema pode estar na falta de multidisciplinaridade na nossa cabeça, enquanto pesquisadores, docentes e professores. Por isso, eu pergunto: de que maneira nós estamos nos preocupando e conseguindo efetivamente introduzir na cabeça dos jovens essa multidisciplinaridade? Porque nós somos, de alguma maneira, reféns de uma formação que nós recebemos. $\bigcirc$ momento histórico de hoje é nosso. Nós somos os professores. Eu pergunto se os meus alunos de graduação na Faculdade de Direito, ou até no Mestrado ou Doutorado, são incentivados a buscar essa multidisciplinaridade, por meio, por exemplo, de disciplinas optativas.

Quando eu comecei a Faculdade de Direito de Ribeirão Preto e fizemos um projeto pedagógico diferenciado, eu dizia para os meus alunos: "eu quero que, se você tem interesse na música, faça uma disciplina de História da Música no Departamento de Música. Isso é importante para sua formação cultural, intelectual, até como jurista no futuro. Se você gosta de futebol, então procure a Educação Física de Ribeirão Preto e faça uma disciplina lá, ou seja, procurem outros fundamentos teóricos". A minha reflexão é: até que ponto nós estamos tão preocupados com essa questão de distribuição de áreas de conhecimento e deixamos de lado essa percepção, que pode, inclusive, influenciar essa distribuição?

Nós nos sentimos confortáveis em nossa área. A multidisciplinaridade é um desafio. Talvez, no cientista de hoje, falte um comum denominador um 
pouco maior. Talvez falte balancear um pouquinho mais. Isso vale para todas as áreas: as exatas mais abertas para uma tradição humanista e artística; as áreas de humanidades, para as ciências duras etc.

\section{4)Prof. Dr. Fritz Cavalcante Huguenin (FFCLRP)}

Há um outro problema, cuja solução poderia ser a alteração da forma de ensino no Brasil: o ensino é muito conteudista. Desde o Ensino Médio, em que se estuda para um vestibular, e a Graduação, há muito conteúdo e pouca reflexão. Nós implementamos uma forma, na Química experimental e na Físico-química experimental, que é colocar um problema. Em vez de dar uma receita de bolo para o aluno fazer o experimento, propõe-se um problema para ele resolver. Dessa forma, incentiva-se o aluno a procurar, naturalmente, outras áreas do conhecimento.

15) Profa. Dra. Adelaide Faljoni-Alario (UFABC)

A UFABC foi criada como resultado das discussões na USP e na UFRJ para se colocar uma formação na Graduação com base nas interfaces dessas caixinhas das áreas do conhecimento. $\bigcirc$ Prof. Bevilacqua foi refugado em diversos momentos na UFRJ. Tentou-se até comprar um terreno na Baixada Santista, que tem mais ou menos a origem da UENF, para se pôr esse modelo. Nem assim passou no Conselho Universitário.

Além disso, eu era lotada - que é outra palavra horrorosa - no Departamento de Bioquímica. Eu representava o Instituto de Química. Nas exatas também, porque o nosso Instituto é anfótero. Em relação à interdisciplinaridade, o Brasil está à frente do mundo inteiro. Na década de 80 e 90, os coordenadores de programas de Pós-Graduação foram corajosos e mandavam os APCNs para a CAPES. Não cabiam em nenhuma das 44 caixinhas que estavam lá, disciplinares pela ordenação. $\bigcirc$ Prof. Luiz Bevilacqua da UFRJ percebeu que havia propostas de programas de Pós-Graduação que eram interessantes e que poderiam ser de máxima significância para o desenvolvimento do Brasil. Para além 
de questões financeiras, ele estava preocupado com o desenvolvimento do Brasil.

Apesar de todas as críticas que temos, o Agronegócio é o que sustenta o PIB brasileiro e que faz pareamento com a região do $A B C$, que, na década de 70, sustentava o PIB do Brasil. $\bigcirc$ agronegócio não cabia nas Agrárias, porque tinha muita economia, muito ambiente, muita química de solo. Ou seja, trabalhava-se nas interfaces: não era possivel ficar na administração, na economia ou na engenharia de transporte. Por consequência, eles ficavam numa "nuvem", termo que nós usávamos. Nela, estavam a Cultura e Sociedade na Amazônia, a Cerontologia, que não cabia muito nas medicinas, a Ambiental, o desenvolvimento de pequenos negócios, a agricultura familiar. Até que se juntaram 46 programas na CAPES na nuvem. $\bigcirc$ que o Bevilacqua fez? Inteligentemente, propôs a criação do interdisciplinar. Aceitaram, mas com a palavra multidisciplinar.

Em novembro de 1999, mal virou o século, o Brasil era o único país que tinha formalmente uma área assim. $\bigcirc$ que aconteceu de 99 para cá? As áreas na CAPES, em geral, têm uma média de 60 programas. A interdisciplinar está com 368. Nós não fazemos "propaganda". São as bases, é o que vem de baixo. Afinal, espera-se aprovar um professor de Roraima que, por exemplo, precise estudar fronteira. Se cumprir todos os quesitos, tem que aprovar na interdisciplinar.

A Interdisciplinaridade tem 126 programas de humanidades na câmara dois; Biológicas têm 80; as Engenharias de gestão têm outros 80; e agrárias e desenvolvimento têm uns 60. Reforço que a "Inter" tem 126. Sabe quanto que eles fizeram - não vou chamar de produção ou escreveram ou publicaram? 24.420 livros. Se eu divido pelo número de programas, cada um produziu 193. Nós avaliamos um por um. Um livro L4 vale igual a um Al da Nature, da Science, da Física etc. Mas não deixaram por isso. Eles produziram 11 mil periódicos. Nosso Qualis tem I 1.000 linhas. Eles produziram 117.000 trabalhos técnicos. Nós avaliamos um por um, desde catálogo. Esses números estão no documento da quadrienal.

No entanto, a área interdisciplinar ainda não é bem aceita. Por quê? É possivel medir aquele programa que trabalha com publicações só na Nature, na Science, na área de ciência, da nossa câmara quatro, que é Saúde e Biológicas, e comparar com alguém que faz pequenos negócios lá na câmara um. É possível. Eu tenho um algoritmo com que eu

\section{2}

REV. TULHA, RIBEIRÃO PRETO, v. 7, n. I pp. 236-392, jan.-jun. 2021 
consigo medir sem prejudicar ninguém. Eu tenho que diminuir a diferença entre denominador e numerador. $\bigcirc$ meu algoritmo tem que refletir essa diversidade: eu tenho 368, de Antropologia, Estudos de gêneros até Astrofísica.

Prof. Carlos Nobre, engenheiro, foi presidente da CAPES, trabalhou no INPE e nos fez debruçar sobre o Manifesto de Leiden. $\bigcirc$ Prof. Renato Janine da USP, da Filosofia, nos fez pensar nessa equalização, nesse diálogo de respeito entre todas as áreas. Por isso, gostaria de render o mérito a eles, o Luiz Bevilacqua, o Carlos Nobre e o Renato Janine.

É muito gostoso o conforto disciplinar. No entanto, aventurar-se para trabalhar nas interfaces custa, mas o produto é bom. Nós, eu e o Prof. Bevilacqua, fomos criticados por colocar vaga para 700 docentes. Havia 200 docentes, de 100 passamos para 200 na UFABC. Nós seríamos responsáveis por colocar 100, 200 jovens doutores numa Universidade que era linear, que não tinha picos de "essa área é melhor, a outra é melhor". Nós não temos departamento também. $\bigcirc$ centro já complica um pouco. No centro de Engenharias, encontram-se as Ciências Sociais Aplicadas, em que o Engenheiro atende à sociedade. $\bigcirc$ cientista social aplicado tem que estar lá. Mas as humanidades, onde está? No centro das Ciências naturais, Física, Química, Biologia, História da Ciência. $\bigcirc$ curso de Filosofia está no meu centro: há licenciatura em Filosofias etc. Nunca conseguimos no CNPa colocar uma área interdisciplinar. Quem está na área interdisciplinar não pode ter bolsa de pesquisador. Quando é muito bom o currículo, escuta-se falar: "bom entra na Bioquímica, entra na Física, na Química", mas não tem bolsa. Então há falhas ainda.

Há um grande colégio das Humanidades na CAPES, da Saúde ou da Vida e das Exatas. $\bigcirc$ interdisciplinar já deu quatro filhos: o Inter é o 45; o 46 é Ensino, que nós não tínhamos no Brasil, pois estava junto com a Educação; nós temos Materiais, Biotecnologias e Ambiental. Agora, avaliar não é bom nem para quem avalia e nem para quem é avaliado. Eu diria que é perverso: quem avalia passa mal, quem é avaliado passa mal. Não há outra alternativa.

16) Prof. Dr. André Luís Giovanini Micheletti (FFCLRP)

\section{3}


Menciono um conceito que é muito caro para a música: a práxis. Nós não fazemos uma divisão entre poíesis e práxis. Afinal, como nos medir? Eu sou o quê? Eu sou um músico. Se eu sou um músico, qual é a minha produção? $\bigcirc$ que meus alunos produzem? Arte, música, paper, livro. E como medir isso? Se é um músico, é um "praticão". Quantas vezes, da maneira mais descabida, os alunos são enxotados, segregados e diminuídos, por serem músicos? A grande contradição disso é que, para Boécio, o músico não trazia essa diferenciação. $\bigcirc$ músico é aquele que leva a retórica musical para o palco: o ato da performance é retórico por si só. No momento do palco, existe a empatia do público com aquela pessoa, com aquele artista; existe a lógica do discurso musical, no lógos. No estudo de, às vezes, 10 ou mais horas diárias desse aluno, há éthos, a ética com que ele trata, e até moral, do latim, ainda sem essa dicotomia feita entre os dois significados (a moral como ética que ele tem com seu próprio estudo, sabendo que o palco é um momento importante e de respeito com aquelas pessoas com as quais ele está criando essa empatia). Essas horas de estudo que os alunos têm para com a música não é de "pura macaquice", como muitos professores de disciplinas, dentro das Faculdades de Música, definem. Isso não existe, não é "macaquice" nenhuma. Dizer dessa maneira é pegar toda a concepção aristotélica da ética e da phrónesis e "jogar no lixo".

Todas as vezes em que um aluno estuda durante horas, seja só a música ou tudo aquilo que pode agregar no momento da performance, não se considera toda a formação musical. Nota-se a interdisciplinaridade dentro da própria Faculdade de Música: quando um aluno estuda contraponto, ele está estudando a retórica em música quanto à linguagem da própria música. Cada um dos tratados de contraponto, que não são poucos, é uma instituição retórica por si só. Cada um dos tratados de performance que os alunos leem, para que embasem historicamente a sua performance, é retórica. Nesse momento em que o aluno tem esse estudo, ele se aproxima da invenção da música, não da criação musical enquanto composição, ele se aproxima daquele que inventou aquela composição, a inventio. Assim, ele tem toda a disposição da música, a forma com que ela foi escrita, a dispositio. Quanto mais ele tem contato com essa literatura e com o estudar o seu instrumento em relação a todos esses tratados, mais ele cria sua própria eloquência. Disso, há a memória de tudo aquilo que the foi ensinado e de toda a tradição musical, não somente a memorização de uma música para tocar no palco. Ele pode ler a música, mas a memória de tudo aquilo, que é a arte que nós conhecemos, está exposta naquele momento.

\section{4}

REV. TULHA, RIBEIRÃO PRETO, v. 7, n. 1 pp. 236-392, jan.-jun. 2021 
Mas o que é a música sem actio? Eu desconsidero a práxis? Descarto a ação de se fazer música? Isso é menor? De jeito nenhum. Mas ninguém olha para o músico e o avalia pela sua ação. Se música é retórica, mas The tira a ação, é uma retórica manca, amputada? Desprovida, pois, de qualquer lógica? Dessa forma, descartam-se Aristóteles e Quintiliano. Acaba-se, por consequência, com qualquer ponte que se faça de universalidade entre a música ou qualquer outra disciplina.

Essa é uma avaliação que se faz não apenas do aluno, mas do professor. É tão falha que eu não posso nem chamar de avaliação. Dentro da universalidade e da aceitação que nós buscamos nessa interdisciplinaridade, em que parte se encontra a Arte? Onde está a expressão daquilo que é mais importante para o ser humano e que o conecta com a nossa antiguidade grega? No momento da ação, eu sou o veículo daquilo que foi a inventio do compositor.

Infelizmente, a performance é vista com muito preconceito. Para além do desabafo, quero trazer a discussão: como me medir? Quer que eu escreva? Escrevo. Quer que eu publique um livro? Publicar. Mas, desse modo, na concepção de Boécio, eu sou um músico medíocre. Eu estou dentro da Universidade de São Paulo para criar cidadãos e músicos muito mais capacitados do que eu, e não espelhos da minha mediocridade.

\section{7)Prof. Dr. Rubens Russomanno Ricciardi (FFCLRP)}

Heidegger fala sobre o esquecimento do ser. Nós podemos dizer que existe um esquecimento da práxis e da poíesis na Universidade. A poíesis, a elaboração crítico-inventiva da obra de linguagem, está esquecida. Por exemplo, em concertos, procuramos apresentar música contemporânea, incluindo a nossa própria produção departamental da USP de Ribeirão Preto, porque nós não podemos abrir mão de um exercício de contemporaneidade. No entanto, falta reconhecer o que é a práxis e a poíesis artísticas dentro da Universidade. $\bigcirc$ lógos (ao mesmo tempo inteligência e linguagem) do ser humano abrange sua capacidade científica, crítico-filosófica, de inventar engenhos funcionais, tais como nas engenharias, na medicina e na odontologia, entre outras, inventar, também, obras de linguagem nas artes, e, por

\section{5}

REV. TULHA, RIBEIRÃO PRETO, v. 7, n. I pp. 236-392, jan.-jun. 2021 
fim, de performance corpórea - aqui expondo uma hipótese nossa de trabalho. Propomos assim pelo menos quatro desdobramentos do lógos humano: 1) Homologia - a propensão de indagar, investigar, analisar, de induzir experiências, de procurar compreender e pensar de acordo com a natureza, daí homologar, ter o mesmo lógos das leis do universo (o lógos dos cientistas da natureza, incluindo os estudos da vida); 2) Lógos filosófico ou hermenêutico-dialético - interpretação e questionamento das contradições do mundo da vida (o lógos do pensamento crítico); 3) Lógos poético - define a condição de poíesis, de inventar linguagens em obras de arte e de engenharia, entre outras invenções (o lógos dos artistas da poíesis, dos engenheiros, alguns setores da medicina e da odontologia, e demais inventores); 4) Lógos corpóreo - interação da mente com o corpo, com a performance corporal nas mais diversas habilidades em seus movimentos, ou seja, as destrezas práticas do corpo humano (o lógos dos artistas da práxis nas artes representativas e dos esportistas, entre outros). Com essa perspectiva, sabemos que a homologia ou o lógos das ciências da natureza, o assim chamado conhecimento teórico-empírico-matemático, em seus fundamentos físicos, químicos e biológicos, já estão em parte contemplados na universidade. Por sua vez, o lógos filosófico precisa ser mais bem compreendido enquanto pensamento crítico-teórico fora do método científico. Já o lógos poético, presente não apenas entre os artistas da poíesis, mas em diversas outras áreas, como as engenharias e em setores da medicina e da odontologia, entre outras, bem como - lógos coporéo, como entre os artistas da práxis e os esportistas, andam ignorados, bem longe de obter o reconhecimento e o incentivo necessários - a produção poética ou prática vale sempre menos na academia.

Ademais, a poíesis e a práxis não podem sucumbir diante das amarras redutivas da CAPES, quando a produção artística só vale se atrelada a uma linha de pesquisa. Essa coerência imposta pela CAPES a uma linha de pesquisa e a uma identidade do programa, submetidas ainda a um documento de área, muitas vezes, mata, no ninho, a liberdade, que é a essência da arte.

$\bigcirc$ Prof. Hilton Japiassu, grande estudioso das questões epistemológicas, dizia o seguinte, em um e-mail que ele me enviou pouco antes de morrer: "temos que tentar reduzir, pelo menos em grande parte, esta tradicional oposição artificial criada por espíritos sectários entre o pensamento artístico, frequentemente qualificado de pré-lógico ou

\section{6}

REV. TULHA, RIBEIRÃO PRETO, v. 7, n. I pp. 236-392, jan.-jun. 2021 
irracional, e o pensamento lógico-racional-científico, numa palavra, entre o racional-objetivo e o irracional-subjetivo, emocional ou passional. Temos ainda que reforçar o atual questionamento que se faz em torno das fronteiras do saber". Até hoje, o que se faz em arte é definido como irracional subjetivo. Há, nessa lógica, as tais ciências chamadas exatas ou, ainda pior, como alguns dizem, a tal hard science, com sua racionalidade objetiva. Devemos pensar antes, contudo, no lógos da phýsis, enquanto conjunto harmônico de leis e linguagens físico-químicas e biológicas do universo, abrangendo a totalidade do cosmo (galáxias, estrelas, planetas, luas, cometas, buracos negros etc.) e todas as formas de vida. Portanto, temos que saber distinguir a poíesis da phýsis (creatio), de um lado, da poíesis do lógos humano (inventio), de outro. Com o esquecimento da poíesis, já há muito esquecemos também as diferenças entre inventio (invenção humana) e creatio (criação da natureza). Aliás, os antigos sabiam diferenciar a criação da natureza das invenções do ser humano. Falta-nos humildade e respeito diante da natureza. Por fim, já temos mais de 3.000 anos da maior revolução cognitiva da História, que foi o surgimento das artes, ciência e da filosofia na Grécia, quando os gregos elaboraram, pela primeira vez, o conjunto indissociável da poiesis com a práxis e a theoria.

\section{8)Prof. Dr. Ricardo Bologna (ECA)}

Nós, que somos da área artística, sentimos falta de reconhecimento sobre a nossa criação interpretativa ou performática. Nós somos confrontados com a produção dos papers. Também, existe uma questão muito paradoxal no ensino da música no Brasil: o artigo científico em música é esperado numa área em que não existe formação de Graduação, que é a Musicologia. A musicologia formaria cientistas da música, que produziriam papers. Logo, principalmente na Pós-Graduação, os músicos que não tiveram essa formação são obrigados, rapidamente, a virarem musicólogos de uma certa forma. Há, portanto, uma contradição em termos de adequação ao academicismo universitário.

Nós produzimos arte no palco, em interação com o público. Existe um trabalho de pesquisa muito grande por trás disso, que, em geral, não é vista. Estuda-se durante anos, antes até da Universidade. Para entrar na Universidade, já tem que saber tocar um instrumento.

\section{7}

REV. TULHA, RIBEIRÃO PRETO, v. 7, n. I pp. 236-392, jan.-jun. 2021 
Sobre interdisciplinaridade: antes de ser músico, eu queria ser astrônomo. Parece que somos todos levados para a Astronomia. Mesmo eu sendo filho de músicos, sob uma influência avassaladora da música na família, até aos 16 anos, eu queria ser astrônomo. Sou fascinado por essa área, sempre fui fascinado. Há, portanto, uma possibilidade interdisciplinar entre as artes e as ciências. Por exemplo, há algum tempo, um programa de uma orquestra portuguesa fez uma série de concertos em que um cientista fazia uma palestra a respeito de um tema que aquele programa musical abordava. Havia profissionais de outras áreas - um Físico, um Biólogo - que faziam uma palestra antes do concerto, com interação, em uma sinergia entre as áreas.

Seria importante se um estudante de música dos nossos departamentos pudesse ter também matérias como Literatura, Física, Acústica etc. A Física e a Música, afinal, são coirmãs, porque, de certa forma, possuem questões paralelas, além de interações com outras formas artísticas que também não existem dentro da Universidade. Por outro lado, embora o Teatro esteja próximo, espacialmente, da Música, há pouquíssimas atividades em conjunto (da mesma forma, com as Artes Visuais). Enfim, as próprias formas artísticas dentro da Universidade são extremamente setorizadas, extremamente isoladas. De certa forma, parece que cada um quer garantir o seu, competir de certa forma. Isso, em se tratando de arte, é a pior postura.

\section{9)Prof. Dr. Luis Afonso Montanha (ECA)}

Costumamos focar sempre em um tipo de conhecimento. Hoje em dia, se continuarmos fazendo isso, provavelmente estragaremos o futuro do aluno, dando-lhe apenas uma possibilidade. Não posso mais formar, por exemplo, um clarinetista para trabalhar numa orquestra, que provavelmente não existirá mais, porque a política não quer que exista. Hoje em dia, os jovens têm a oportunidade de uma inserção no mercado de trabalho com projetos socioculturais. Ou seja, existem orquestras vinculadas a projetos de comunidades etc. Mas, depois disso, onde essa pessoa trabalhará? Como a Filosofia, a Música está sendo dizimada.

É difícil manter uma classe, com motivação. Por que o aluno faria uma faculdade para apenas tocar em casamento?

\section{8}

REV. TULHA, RIBEIRÃO PRETO, v. 7, n. I pp. 236-392, jan.-jun. 2021 
No universo da avaliação, o que mais me assusta é realmente o preconceito que existe dentro de cada área. $\bigcirc$ problema não está somente na CAPES, na FAPESP, na avaliação, está dentro do nosso próprio departamento. Quando os fundamentos foram estabelecidos, talvez as pessoas da performance não estavam tão envolvidas. A área foi desenvolvida por meio dos musicólogos, tecnólogos etc. Uma vez falei: "bom, já que vocês consideram a música como uma ciência, então que pelo menos trate como tal", porque o departamento não pode usufruir de um instrumento. As outras áreas não têm a noção da situação precária em que vivem essas áreas, quase subáreas do conhecimento. Será que na área de Medicina, o cirurgião consegue trabalhar com um facão? É possível extrair uma pequena veia com um facão? E o que pode fazer o instrumentista com um instrumento desafinado e quebrado? $\bigcirc$ departamento não tem verba, sequer é respeitado para conseguir.

\section{0) Profa. Dra. Ana Cristina Zimmermann (EEFE)}

Nós estamos, de fato, exercendo os papéis para os quais nós fomos designados. Nossa função na Universidade é essa: discutir o conhecimento ou a produção de conhecimento. Sinto-me privilegiada nesse momento porque, na maior parte do nosso tempo, nós estamos destinados a tarefas burocráticas, enfim, que reduzem a nossa capacidade. $O$ curso de Educação Física, que é um curso bastante recente na área acadêmica, está bem no meio do turbilhão dessa discussão.

Quando eu fiz o curso de Educação Física, estava-se inaugurando a ideia da disciplina optativa. Nós começávamos a circular pelo campus para buscar disciplinas em outros cursos. Eu fui buscar disciplinas da Filosofia. Porém, eu escuto o seguinte senão: "você não pode fazer disciplinas aqui". Respondo: "por quê? Eu vejo no sistema que há vagas". Ouço: "não, porque aqui a gente lê". Eu pensei: "essa habilidade eu já aprendi no Ensino Fundamental; eu acredito que seja pré-requisito cumprido". Então falei: "eu sei ler". Responderam: "não, aqui nós lemos livros inteiros". Essas dificuldades vão além desses muros, bem mais espessos do que se imagina ou reconhece. Há preconceitos bem enraizados entre as diferentes áreas. 
A maior crítica que temos em relação ao nosso currículo é que os nossos alunos não têm experiências com as práticas corporais suficientes ou necessárias. Com isso, eu não quero dizer que, além de "jogar bola”, estudamos, lemos, pensamos. Talvez a nossa contribuição esteja na ousadia ou insensatez de atribuirmos um status para o saber corporal. Com isso, provoca-se o conhecimento ou a produção do conhecimento. Nós temos uma especificidade que pode agregar a discussão.

A questão principal da Educação Física é o movimento: um movimento que não é o movimento de um objeto, mas um ser humano que se movimenta. É um corpo que não é somente um fenômeno biológico; é um fenômeno humano, portanto, histórico, antropológico etc. Que corpo é esse, afinal? É um corpo biológico? É uma construção discursiva?

A Educação Física está na área da saúde, porque existe uma questão histórica obviamente. É confortável estarmos na área da saúde, porque nós encontramos uma utilidade, isto é, uma função social, porque é uma área que não têm "utilidade". Jogar serve para quê? Coloca-se um desafio que inexiste. Cria-se esse desafio para se testar frente a esse desafio. Frente aos outros, é inútil nesse aspecto. Na saúde, encontramse uma utilidade e um certo status. Das áreas biológicas ou das ciências biológicas, há uma lógica hegemônica, que opera dentro da nossa área, principalmente, nas avaliações.

Historicamente, consolida-se a rejeição de aproximação com as artes. Há uma briga histórica com a dança, por exemplo. É melhor aproximar-se do Instituto da Medicina e da Biologia do que se aproximar da ECA, por exemplo, em termos de status. Por outro lado, embora se encontre a nossa utilidade na saúde, não é nela que se encontra significado, não na esfera da utilidade. Logo, esporte não é saúde, se entendermos saúde no sentido estrito. Esporte ou práticas corporais é, portanto, desejo, vai para a linha da expressão, vai para outra dimensão. Esse significado está nas Humanidades, em nossas possibilidades expressáveis.

Como a área acadêmica é muito recente, os primeiros cursos de Pós-Graduação são aqui da USP da EFE, especialmente, no final dos anos 70. Os primeiros cursos de Pós-Graduação da América Latina na área são muito recentes como produção. Por ser jovem, há bônus e ônus. Nós temos essas dificuldades, um grande embate: quem somos nós, o que produzimos, o que somos capazes de produzir, qual é a 
nossa contribuição? Por outro lado, há possibilidade de trazer alguma novidade ou imprudência nas proposições: trazer o corpo para a Universidade.

Eu ouvi, em uma palestra, que o corpo, na Universidade, é muito importante para carregar as cabeças para as reuniões. A corporeidade, considerando o movimento humano, com todas as suas contradições e ambiguidades, reforça ou reconfigura essa questão sobre a humanidade do homem, nossa humanidade. $\bigcirc$ que é pensar em si próprio, que nos toca, que nos move, que nos mobiliza? Por exemplo, a noção ampliada de jogo pode nos ajudar a pensar a relação dialógica. $\bigcirc$ diálogo foi falado bastante. Foi falado que o diálogo é uma guerra. No entanto, sugiro repensarmos a ideia de vencedor e vencido, porque é uma lógica operante também no esporte. Nela, subjuga-se, perdendo todos os outros elementos que o jogar, o esporte e as práticas corporais trazem de contribuição sobre nós mesmos. Trata-se da experiência do encontro. $\bigcirc$ jogo tem essa esfera lúdica no sentido de que nós estamos passando por um conflito. Certas questões nos desagradam, mas, ao mesmo tempo, há um certo prazer de estarmos aqui confrontando, reforçando e reformulando nossas posições. Eu aposto nessa nossa capacidade de se colocar em relação ao outro, na postura do desafio, da provocação, no sentido de convite ao que está por vir, tal qual no jogo.

Os maiores debates que eu tenho presenciado na Escola de Educação Física e Esporte acontecem nas reuniões do Comitê de Ética. As pessoas que estão ali presentes estão, realmente, discutindo ciência. Temos, por conseguinte, dificuldades em função da nossa história, da nossa colocação como área da saúde. Na área sociocultural, também, estamos com dificuldades. Com a área pedagógica não é diferente.

Temos um projeto, em parceria com o CINUSP, intitulado "Cinema e Corpo". Desde 2012, esse projeto vem acontecendo, com parceria, também, de vários professores da Literatura, da Filosofia, da Enfermagem, do próprio Cinema. Nas avaliações dos professores participantes, houve destaque com o caráter interdisciplinar do projeto, como se fosse uma novidade. Porém, isso não deveria ser uma novidade. Criamos esse projeto justamente para ampliar nossas reflexões sobre o corpo e, preferencialmente, não convidamos ninguém da nossa área para debater. Sempre são pessoas de outras áreas, em esforço de mobilização. 


\section{1 ) Prof. Dr. Rubens Russomanno Ricciardi (FFCLRP)}

Uma parte fundamental deste Seminário, indiscutivelmente, é a necessária aproximação entre a música e o esporte, principalmente para a formação das nossas crianças e dos nossos adolescentes. Por sinal, a próxis nas artes representativas contempla o mesmo lógos corpóreo que a práxis dos atletas nos esportes. Não há método pedagógico que supere o esporte e a música na formação de nossas crianças. Já o teatro talvez não possa ser praticado de modo tão precoce, pois exige uma maturidade na práxis que as crianças pequenas não têm. Já a música, quanto mais cedo começar, melhor; assim como o esporte. Por meio do esporte e da música, nós damos noção de coletividade e trabalho conjunto, de autoestima, de internacionalização, de respeito e hierarquia, beneficiando até a saúde e a segurança das comunidades envolvidos. Quanto a projetos de música, nós temos alguns, tais como em São Joaquim da Barra, sob mecenato de meu amigo Carlos Alberto Nicolau. Nós temos lá o projeto USP Música Criança, além do polo de Ribeirão Preto, em parceria com a FMRP-USP.

Seria importante, nesses projetos de música, ter, também, o projeto de esporte no contraturno. Há crianças que têm mais talento para o esporte do que para música; outras têm mais para a música; outros são bons nos dois; já outros em nenhum dos dois. Mas o interessante é que estas, ainda assim, desenvolvem noções sólidas de cidadania, com desempenho melhorado nas demais disciplinas, tirando as crianças das drogas (incluindo a indústria da cultura) e dos demais caminhos menos favorecidos. Trabalhamos isso com crianças de comunidades precárias financeiramente e realmente funciona: elas se descobrem como artistas, como esportistas, como cidadãs. Não existe melhor educação que esteja fora da música e do esporte.

Prof. Alexandre Silva Costa, que tem conhecimento de grego, sabe que aqueles que inventaram o teatro e a tragédia grega inventaram, também, as olimpíadas, num processo confluente. Inclusive, a palavra mousiké, originalmente, nem excluía o que seria hoje a educação física, ao lado das artes ditadas pelas musas.

\section{2}


Nós estamos trabalhando com um tipo de educação conceitual e metodológica. Fala-se muito em método. Ouvimos muitas pessoas da área da pedagogia falar em método. Para além do método, é importante a práxis. Lembremo-nos do conhecido ditado de Juvenal (poeta romano dos séculos 1/II): "uma mente sã num corpo são". A frase original, porém, expressava justamente uma crítica contrária à religião: "deve-se rogar para que uma mente seja sã num corpo sadio. Isento do terror da morte, peça um intelecto forte, que considere o intervalo entre os extremos da vida um presente da natureza". Devemos levar a sério a sabedoria antiga desse poeta satírico, o qual desacreditava seus conterrâneos, cujas preces the pareciam absurdas. Devemos antes focar nossas relações com os deuses na preservação de nossa saúde física e mental - já que todo demais tipo de reza é insanidade. É fundamental, portanto, interagir o corpo humano com a mente, tal como a práxis no lógos corpóreo. Essa é a verdadeira saúde física e mental.

\section{2)Prof. Dr. Oscar João Abdounur (IME)}

Na matemática, também se pode trabalhar numa área que seria História, Filosofia e Didática da Matemática. Nesse sentido, eu tinha a imagem de vários "Versos" ao entrar na Universidade. Eu imaginava que faria pesquisa com outros profissionais: biólogo, músico, físico. Não foi bem assim. Existia uma dificuldade de conseguir um feedback com outras áreas, por exemplo, a Arquitetura. Havia uma distância entre o que era dado em cálculo e o que eles usavam em arquitetura também. Na ECA, onde lecionei por quatro anos fundamentos acústicos da música, havia um certo apoio. Eu dava aula voluntariamente, não contava em carga didática.

Depois que eu saí de São José, vim para Matemática. Fiz Mestrado em Geometria e doutorado em heurística, dentro da Matemática. Como eu estava muito envolvido com a música, resolvi fazer alguma relação entre a matemática e a música do ponto de vista didático. Comecei a desenvolver muito essa parte interdisciplinar. Porém, comecei a ver algumas dificuldades que tinha, especialmente quando eu pedia auxilio. Já apresentei pedido de verba que não foi aceito porque, como me disseram, "eu estou insubordinado à área de conhecimento". Foi falado: "você está insubordinado, diferentemente de alguém que está numa

\section{3}

REV. TULHA, RIBEIRÃO PRETO, v. 7, n. 1 pp. 236-392, jan.-jun. 2021 
área clássica, você tem que provar muito mais vezes a pertinência do teu projeto".

Com o tempo, isso foi mudando. Acabei fazendo Pós-Doutorado na Alemanha, no Instituto Max Planck, em Berlim. Na verdade, lá é uma itha, especialmente na História da Ciência. Eu trabalhava com a parte da matemática medieval e grega. Eventualmente, precisava de pessoas do Latim, Filólogos etc. Eu tinha sempre pessoas com quem eu poderia conversar, logo pude viver um pouco o ambiente interdisciplinar.

$\bigcirc$ Prof. Ignacio comentou sobre a questão da mentalidade. Isso está relacionado a quase uma formatação burocrática da inteligência - não burocrática no sentido de burocracia como uma técnica administrativa, porque é impossivel viver sem a burocracia nesse sentido - mas burocrática no sentido mais negativo. Por exemplo, sobre o texto de meu orientando, sugerem: "não Oscar, vamos dividir em três, porque assim eu consigo ganhar ponto não sei aonde". Para poder dar mais pontos. Afinal, ele quer acabar o Doutorado e, provavelmente, fazer um concurso. Haverá uma banca burocrática que fará a contagem. Não há muita saída, ou se rende a isso ou morre, ou academicamente ou financeiramente.

A mentalidade permanece. Na FEA, durante as aulas de cálculo, é comum escutar aquelas perguntas: "vai cair na prova?"; "isso cai? Como eu tenho que fazer para não sei o que..?" Enfim, o aluno está preocupado em, obviamente, passar. É claro que tem um ou outro que também está interessado. Porém, no perfil social, a maioria está preocupada em fazer o formulário. Eles vêm com uma formação assim, porque resolverá o problema. Eles já instituíram um hábito, uma tradição de ter alguma fórmula. A escola acaba nos treinando para isso. Ela treina disciplina, principalmente, ela treina rotina: ela tem um conhecimento que é feito "até aqui, depois até aqui, depois até lá". Na verdade, ficamos longe do que seria a posição do conhecimento, se for pensar historicamente. Eles têm o diploma - na prática, o diploma e a disciplina - A escola torna-se formação para o trabalho, para a civilidade e para adquirir um conhecimento geral.

Eu faço um teste com meus alunos do primeiro ano: pergunto a alguém se ele se lembra de quem é Jacobino ou o que é uma mitocôndria. Parece que esse conhecimento não fica; o que fica é o 
diploma. Habitua-se a esse formato. Por isso, a mentalidade é central nessa questão.

A maior dificuldade chamo de formatação burocrática contra a inteligência. Cito outro exemplo: em uma banca de Pós-Graduação, um aluno fez uma apresentação brilhante. Mas, no meio de seu texto, ele citou Vigotski de forma não articulada com o resto do trabalho. Eu comentei: "achei ótimo, só não entendi aquilo". Respondeu-me: "ah, é que o orientador falou para colocar".

\section{3)Prof. Dr. Sidnei Oliveira (FFCLRP)}

Também acho significativo juntar todas as áreas o máximo possivel, ainda mais em relação à educação no sentido de como ela está hoje, fragmentando-se cada vez mais. Da mesma forma, é importante sensibilizarmos ao fenômeno da extinção das áreas de Humanas. Devemos lembrar que são os docentes que estão à frente da CAPES e do CNPa. Se há um problema em relação à Qualis, por exemplo, são os docentes que estão fazendo isso. Há uma questão dentro do próprio departamento, há uma questão da Instituição e, também, do docente que está indo para CAPES.

Em relação à extinção dos cursos de Humanas, a pergunta é: qual a ação real da instituição da Universidade, dos próprios docentes, do presidente da instituição de ensino e de pesquisa? Parece que a única atitude é no meio intelectual. A prática fica apenas no meio virtual, no sentido de notas de repúdio. É insignificante, sendo radical: notas de repúdio em grupos de estudo e sites da própria instituição, assim como em curtidas e compartilhamentos em redes sociais. Qual é a posição e preocupação real de um docente para mudar a atual circunstância a respeito da possivel extinção das Ciências Humanas em Universidades Públicas, pensando que o reflexo que isso acarreta é, principalmente, no Ensino Básico? Afinal, são professores dentro de uma instituição que formarão os futuros professores. Nem todos vão para a academia. Mais de cinquenta por cento vão para a rede pública ou privada. Quanto à rede privada, ela mantém as Ciências Humanas, porque a área não sai de um vestibular. A rede pública, no entanto, será deficitária nesse 
sentido. Esses alunos que são formados, quando não são bacharéis, embora licenciados, não vão ter onde trabalhar.

Eu sou formado em Filosofia e em Música. Dentro da academia, minha pesquisa sempre foi Filosofia da Música. Hoje eu me voltei para uma pesquisa em que olho para o Brasil, tratando da questão da cultura popular e da viola caipira. No mestrado e no doutorado, sentia-me incomodado, porque eu estudei Nietzsche, Schopenhaver e Wagner. Na Alemanha, com o intercâmbio em Berlim, parecia que eu sabia mais da Alemanha do que eles. Quando se estuda Música ou Filosofia, costuma-se ir para lá, para saber mais deles do que de nós. É como se a academia estivesse de costas para o próprio Brasil ou para a própria América Latina. Hoje falando sobre o Brasil, a cultura popular e a viola caipira, eu tento trabalhar com pensadores brasileiros, para poder dialogar de uma forma com que seja mais Brasil.

Afinal, qual é a posição atual de um docente, de uma instituição, perante o sucateamento da educação, que está sendo refletida principalmente na educação básica? Por exemplo, por ser vinculado à ANPOF (Associação Nacional de Pós-Graduação em Filosofia), recebo e-mails semanalmente, quinzenalmente. Dois anos atrás, eu recebia e-mails de concursos. Todos os concursos eram para Universidades Públicas. Depois dos acontecimentos com o Brasil - que todos sabem -, os concursos indicam que o Estado está pagando R\$ 16,00 a hora/aula. Dentro de uma instituição, como a ANPOF, não se posiciona. Nos sites, a primeira matéria que apresenta na página é uma nota de repúdio. Mas não se vê, em situação alguma, uma posição, direta e prática.

\section{4)Prof. Dr. Tito José Bonagamba (IFSC)}

Embora seja físico, uso preciosamente meu tempo, enormemente, com questões de música, arte, pintura. Passo meu tempo na Escola de Educação Física e Esporte de Ribeirão Preto, mas também na Unidade de Música. Eu acho as questões da interdisciplinaridade fundamentais. Aliás, dentro da área de Física, em relação ao nosso programa, por ser interdisciplinar, as pessoas que produziam fora do ambiente da Física, da Química Medicinal, publicando nas melhores revistas, não tinham avaliação Qualis adequada no nosso programa. Nós tivemos que 
interferir na CAPES para que essa produção científica, que era Qualis A na área mãe, fosse avaliada da mesma forma no nosso programa. Nós fazemos um papel fundamental de interferir no processo. Não podemos esperar que esse problema seja resolvido pelos outros. Nós temos que resolver com rapidez.

Falo como uma pessoa que se sente parte da Música, mesmo não sendo músico, e do Esporte, tendo sido atleta. Eu gostaria de lembrar que, na USP, hoje, há uma janela de oportunidade fantástica. Os departamentos têm que discutir sobre o projeto acadêmico da sua Unidade e na definição do projeto acadêmico, que está dentro do escopo do departamento. Nós temos que prever o que nós esperamos diretamente dos nossos docentes, no conceito das atividades-fim daquele departamento. É fundamental, pelo mesmo ambiente da Universidade de São Paulo, que todas as pessoas que fizeram uma reflexão de inferioridade ou de falta de reconhecimento falem com os seus chefes de departamento. "Eu quero participar desse processo de definição do projeto acadêmico, porque eu quero ser avaliado tal como eu sou dentro da Universidade de São Paulo".

\section{5)Prof. Dr. Rubens Russomanno Ricciardi (FFCLRP)}

É ideal quando o departamento é ouvido. Quando a congregação não ouve o departamento, o docente fica estrangulado no ninho.

\section{6)Prof. Dr. Tito José Bonagamba (IFSC)}

A proposta da Universidade de São Paulo é que os departamentos se manifestem. Se houver dificuldade, tem que ter o trabalho. Na CAPES e no CNPq, é o mesmo problema. Os professores que estão lá são nossos colegas. Nós temos que nos esforçar intensamente para que haja uma comunicação com eles, porque cada área tem que definir a sua avaliação de acordo com a produtividade. Na música, se não estão vendo o Rubens como músico, me causa espanto. Se, em outras áreas, isso não está acontecendo, é porque não existe a comunicação entre 
a comunidade, que se sente articuladora e produtora do conhecimento naquela área de conhecimento e não é ouvida. É fundamental que haja um movimento. Aqui, eu vejo pessoas de importância na área, que participam desse processo, mas, às vezes, não participam do processo.

Em suma, os departamentos têm que definir o projeto acadêmico, inspirado nesse processo. Na sua área de atuação, na Música da FAPESP, na Música do CNPq, é importante expressar: "olha, esse é o nosso projeto acadêmico e esse é o nosso formato de produção com essas formas, que devem ser avaliadas". Precisamos pensar de cima para baixo e de baixo para cima, a fim de encontrar esses movimentos. É essencial participar.

\section{7)Prof. Dr. Paulo Eduardo de Barros Veiga (FFCLRP)}

Procurando representar a área de literatura, que é também uma área artística, comento que todos os problemas relacionados à arte são também problemas nossos. Na área de Estudos Clássicos, por exemplo, os cursos de grego antigo, latim e indiano antigo correm o risco de "fechar as portas". Na instituição privada, a área, praticamente, não existe. A USP, a UNESP, as poucas universidades públicas, portanto, tornam-se um último reduto. Porém, o sânscrito fechou, o russo, inclusive, fechou. Mas a língua dos antigos indianos, fundamental para todos nós, fechou. $\bigcirc$ curso de grego está como um equilibrista próximo a cair no precipício. $\bigcirc$ latim ainda se sustenta um pouco melhor porque existe um pseudodiscurso da erudição, que não é legítimo, mas pelo menos se sustenta de alguma forma, ainda precariamente. Costaria apenas de comentar sobre o esquecimento das línguas, da literatura e da tradução.

28)Profa. Dra. Icléia Thiesen (UNIRIO)

Nós temos que voltar a pensar no que nós queremos: que sociedade nós queremos? É essa a nossa questão. Queremos a sociedade da competição, da disputa pelo prestígio, da disputa pela verba? Ouvindo os depoimentos dos departamentos e dos cursos, percebi o seguinte: 
é de dentro que nós vamos mudar. A instituição reproduz a sociedade. Se, na sociedade, nós estamos "brigando", nós vamos "brigar" dentro do departamento. Nós somos a CAPES e o CNPq. É ilusão acharmos que eles estão lá e nós estamos aqui. Portanto, nós temos que trabalhar os documentos de área. Toda área tem o seu documento. Eles são debatidos periodicamente nos fóruns das áreas. Nesse momento, temos que interferir ou deixar o rolo compressor passar.

A precarização das humanidades está aterrorizando todo mundo. Ela precisa ser devidamente explorada e denunciada. Na verdade, não se conseguiu terminar com os cursos que denunciam o que está acontecendo no Brasil. Ao contrário, eles se amplificaram pelo Brasil inteiro. Refiro-me às disciplinas que estão sendo dadas denunciando - golpe. Não é por acaso que se quer acabar com as humanidades inteiras, não somente a História. Nas humanidades, há outras ciências que podem abordar esses mesmos temas e denunciar, internamente e externamente. Ao invés de usar essas verbas para acabar com problemas sociais efetivamente - a ciência a serviço da sociedade - fabricam-se armas. Entra-se em um esquema em que sequer se sabe o que o colega do lado faz, porque a máquina é trituradora.

\section{9)Prof. Dr. Alexander da Silva Costa (UFF)}

Pensar sobre as grandes áreas, as pequenas áreas e questões de nomenclatura ou terminologia pode ser sempre muito bem-vindo. É preciso salientar, no entanto, que a ordem da discussão é de política pública. Por exemplo, a junção do CNPa com a CAPES não agrada nem ao CNPq, nem à CAPES. É, senão, um grande truque para fazer desaparecer o que nós temos ou deixamos de ter, seja bom, seja ruim. $\bigcirc$ horizonte de um encontro como esse é nesse âmbito.

$\bigcirc$ Brasil tem sofrido agressões muitas e várias. Por isso, falei sobre a formalização de novo da exclusão da Filosofia no Ensino Fundamental e Médio. Nessa ordem macropolítica, a Universidade tem que se segurar mesmo, porque nos iludimos com que ela esteja segura. Essa ordem é reflexo da sociedade. Num sentido amplo, é o mercado que se confunde com a sociedade, que demanda, impõe e escraviza a Universidade, se 
nós não resistirmos, se nós não nos unirmos. Desde o início, meu discurso volta-se ao horizonte da união.

Com Deus ou sem Deus, somente se movimenta pela contradição. Somente a discordância move; o sim não move. Por isso, agradeço as discordâncias, e agradeço justamente porque isso é diálogo. Quando eu falei de guerra, era em um nível simbólico e bem grego. Diálogo tem um prefixo, "através de", por isso que o termo que eu usei é uma invasão, porque se é abertura é para alguém invadir. Diálogo que não seja invasivo não é abertura, porque se fecha. É por isso que o grego dava como sinônimo semântico ao diálogo a guerra. Em nenhum momento, é briga, mesquinharia, má competição. A arte de se deixar invadir é incômoda. Por isso que sobeja o falso diálogo. Ademais, foi muito usado por mim e por outros o termo provocação, que é trazer a voz para fora. Devemos cultivar essa experiência, entre outras solidariedades.

Além disso, já que a avaliação é inevitável, ela tem que ser mais bem reconhecida. Há, afinal, protagonismos e há, também, coadjuvantes. Não se trata de acabar com avaliação, mas de aprimorá-la. Quanto ao saber corporal, a Universidade não aprendeu a assimilá-lo ainda. Esse é um problema também da Filosofia, porque ela fala de corpo e corporeidade.

Também, chamo a atenção ao sucateamento que o Instituto de Artes da UERJ está sofrendo. Será mera coincidência que a UERJ, o maior exemplo da precarização, é disparadamente a Universidade mais popular do Brasil, a primeira a implantar cotas, a que mais contempla inclusão dos excluídos? Não é coincidência, não é falta de dinheiro, é política seletiva para desmonte de Universidade Pública. $\bigcirc$ sintoma de ser a UERJ a primeira a sofrer isso é, para mim, de uma eloquência cristalina.

Em relação à produção artística, quem faz mestrado e doutorado como é que fica? Eles fazem instalação, escultura, pintura, gravura etc. Mas ao mostrar a produção, que é performática ou é a obra, toda a cultura acadêmica profere: "não, mas você vai ter que escrever uma tese teórica”. Se o faz sobre a própria obra, fica uma situação meio canhestra, porque vão dizer que o artista é narcísico. Ou seja, sofre-se duplamente: é preciso teorizar um trabalho performativo, propriamente artístico, que já é uma concessão ao modus operandi, que desloca o córpus para outro lugar porque não se sabe lidar com ele, e ainda sob 
situações em que se diz: "olha, é narcisismo porque vocês só defendem teses sobre vocês mesmos".

Parece que nós ainda não conseguimos assimilar bem como dialogar com o corpo e como contemplá-lo no corpo do músico, no corpo da produção artística. Há aperfeiçoamentos necessários, em favor da diversidade da unidade. Manter o sentido largo da unidade do diverso é saber onde está o lugar da diferença e contemplar as diferenças, em vez de instituir a lógica da predominância ou do protagonismo, em que se espera, primeiramente, reconhecer que os esforços estão sendo feitos. No entanto, é o pior lugar possível o nosso: a impotência.

\section{Encerramento}

30)Prof. Dr. Rubens Russomanno Ricciardi (FFCLRP)

Eu gostaria de encerrar a discussão agradecendo os funcionários do Instituto de Estudos Avançados. Nós vamos organizar uma continuidade desses trabalhos, em breve. Muito obrigado. 


\title{
Il Seminário (Re)discussão sobre as grandes áreas do conhecimento
}

\author{
IEA-USP \\ 29 de junho de 2018 \\ Link de acesso ao evento: \\ https://www.youtube.com/watch?v=DNgOdvlZAssset=5459s
}

Local: Sala Alfredo Bosi - Instituto de Estudos Avançados da Universidade de São Paulo

Coordenação: Rubens Russomanno Ricciardi (DM-FFCLRP)

Participação dos Professores da USP

Antônio Carlos de Araújo Silva (ECA)

Diego Antonio Falceta Conçalves (EACH)

Eduardo Henrique Soares Monteiro (ECA)

Euclydes Fontegno Marques (FM)

Fernando Crespo Corvisier (FFCLRP)

Guilherme Ary Plonski (FEA, POLI)

Oscar João Abdounur (IME)

Jorge Eduardo Moreira (FMRP)

Lucas Eduardo da Silva Calon (FFCLRP, pós-doc.)

Marcos Aurélio Bulhões Martins (ECA)

Paulo Eduardo de Barros Veiga (FFCLRP, pós-doc.)

Ricardo de Figueiredo Bologna (ECA)

Viviane Abreu Nunes Cerqueira Dantas (EACH)

Wilson Roberto Navega Lodi (FMRP)

Convidados externos

Adelaide Faljoni-Alario (UFABC, CAPES)

Aloysio Moraes Rego Fagerlande (UFRJ)

Antonio Sergio Ferraudo (UNESP)

Luiz Bevilacqua (UFRJ, UFABC, IEA)

Et alii. 


\section{Abertura \\ 31 )Prof. Dr. Rubens Russomanno Ricciardi (FFCLRP)}

Para as falas iniciais, eu gostaria de convidar o Prof. Aloysio Fagerlande (Universidade Federal do Rio de Janeiro), Prof. Euclydes Fontegno Marques (Universidade de São Paulo), Prof. Luiz Bevilacqua (membro ativo do Instituto de Estudos Avançados e professor da Universidade Federal do Rio de Janeiro e da Universidade Federal do $A B C$ ) e Prof. Wilson Roberto Navega Lodi (Faculdade de Medicina de Ribeirão Preto).

No nosso primeiro encontro, levantamos alguns problemas sobre as áreas do conhecimento. Inicialmente, a proposta seria discutir o porquê da divisão entre Ciências Exatas, Humanas e Biológicas. Afinal, como pode uma Biologia ficar apartada da Química e da Física? Afinal, todas contemplam o lógos da phýsis. Ademais, o que seria uma ciência não humana, em relação às humanidades, entendida forçosamente num conjunto único das artes com estudos culturais e a filosofia, as quais são áreas, de fato, tão diferenciadas? Àquela altura, o Prof. Alexandre da Silva Costa levantou a questão do que está ocorrendo, em um momento obscuro do país, em que se procura fechar cursos das humanidades. Também a Profa. Icléia Thiesen, nossa primeira convidada, palestrante da UNIRIO, salientou a importância de trazer ao Brasil o debate do Manifesto de Leiden (2015), justamente a crítica a esse tipo de desempenho, onde se prioriza a quantidade estatística em detrimento da singularidade qualitativa, onde a razão calculadora elimina $\mathrm{o}$ incomensurável, onde a necessidade de internacionalização reduz a importância dos imprescindiveis projetos regionais, incluindo aqueles de importância social, bem como com a obsessão pelos rankings universitários, sempre presentes nas manchetes dos jornais, mas que medem a produção e a qualidade das Universidades por critérios redutivos e arbitrários, eliminando as missões institucionais que devem ser diferenciadas nos mais diversos níveis, desde o professor até o departamento e a unidade.

Nós tivemos colegas, principalmente da área das artes e esportes, - Prof. Andre Micheletti da Música de Ribeirão Preto, o Prof. Montanha e o Prof. Ricardo Bologna da ECA-USP, e a Profa. Ana Zimmermann, da Escola de Educação Física da USP. Eles levantaram também a questão

\section{3}

REV. TULHA, RIBEIRÃO PRETO, v. 7, n. I pp. 236-392, jan.-jun. 2021 
da performance, em especial da práxis enquanto lógos corpóreo, da capacitação psicomotora e do talento profissional, que é pouco levada em consideração tanto na avaliação dos currículos como na contratação dos docentes. Assim, o Prof. Paulo Saldiva e eu, discutindo sobre a continuidade da discussão, percebemos que o momento oportuno é tratar, justamente, da valorização das áreas que requerem uma habilidade profissional prático-poética e que são essenciais não somente na Graduação, mas também na Pós-Graduação, daí também, a necessidade urgente de desenvolver a Pós-Graduação profissional.

Importante salientar a missão que está sendo cumprida pelos recentes e ainda poucos, mas já imprescindiveis, programas profissionais em artes nas universidades públicas. Configura-se, mesmo que tardiamente, uma postura mais ousada dos professores artistas, no estabelecimento de uma produção com maior impacto social. Importa agora valorizar e implantar a pós-graduação profissional, uma vez que a hegemonia da pós-graduação acadêmica deixou lacunas. Não estamos criticando os programas acadêmicos existentes. Apenas reiteramos que não podem ser a única opção, ainda mais porque, não raramente, os programas acadêmicos em artes se confundem com os estudos culturais. Fazse necessário, pelo menos em igual tamanho, o estabelecimento de programas onde a pesquisa se volta à poíesis e à práxis, viabilizando a produção artística. Afinal, os cursos de artes (com poíesis e práxis) não são estudos culturais (só theoria), não obstante suas interfaces fecundas. E não foi apenas nas artes que a pós-graduação profissional tardou a surgir no Brasil. Na História recente do Brasil, houve o golpe militar-burguês de 1964. Mas tivemos, também, outro golpe, que passou despercebido e continua ainda não sendo notado na academia, que foi o golpe da Pós-Graduação. $O$ mestrado profissional foi regulamentado pela CAPES em 1995, ou seja, 30 anos após o Parecer Sucupira de 1965, quando se iniciava o processo de regulamentação da pós-graduação. Newton Sucupira já salientava a necessária dupla modalidade, tanto acadêmica como profissional. Tânia Fischer, em 2010, reconhecia a aplicação aniquilada que a concepção original de Newton Sucupira acabou sofrendo: "a pós-graduação brasileira já foi pensada como um sistema com dois eixos de formação (acadêmica e profissional), sendo exercitado integralmente apenas o eixo acadêmico. É o momento de reimaginar a pós-graduação, reconstituindo-a [tal como consta do Parecer Sucupira], a partir dos possiveis elos entre o que existe hoje e a proposta original. $\bigcirc$ elo principal é o mestrado profissional, que tem uma trajetória difícil, com rejeições explícitas de algumas áreas e dificuldades

\section{4}

REV. TULHA, RIBEIRÃO PRETO, v. 7, n. I pp. 236-392, jan.-jun. 2021 
em ser reconhecido e valorizado". Por conta das diferenças entre as grandes áreas do conhecimento, se a pós-graduação acadêmica é adequada à theoria, nem sempre resolve as questões de poíesis e à práxis, nas quais a pós-graduação profissional tem maior potencial de resultados. Se há erros metodológicos em cientometria, o que diríamos das artes, cujos critérios de avaliação se distanciam de sua natureza?

Viabiliza-se, dentro da estrutura universitária, que necessita de Doutores na Universidade, a contratação tanto daqueles que se destacam pela pesquisa, quanto dos que trabalham com a práxis e a poíesis, ou seja, uma atividade de performance, do lógos poético (lógos da poíesis) e do lógos corpóreo (lógos da práxis). Não sou eu que digo isso, mas Aristóteles, pois "das coisas que podem comportar-se de modos distintos estão aquilo que é poético e aquilo que é prático: pois poíesis [produção] e práxis [ação] são diferentes. (...) De tal modo que a disposição prática segundo o lógos [prático] é diferente da disposição poética segundo o lógos [poético]. Por isso também não se incluem uma na outra: pois nem a práxis é poíesis, nem a poíesis é práxis". Nas artes, o conjunto da poiesis (composição autoral, invenção e elaboração da obra de linguagem) com a práxis (interpretaçãoexecução enquanto processo hermenêutico das fontes da obra que resulta numa ação prático-corporal) chamamos hoje performance. Os artistas da poíesis são poetas e demais autores literários, arquitetos, coreógrafos, autores teatrais, artistas visuais e compositores, entre outros. Podemos conferir equivalências à poíesis com nossos verbos produzir, fazer, fabricar, inventar, compor. A poética (ou poiética, pois se trata também do estudo da poíesis), neste sentido primordial, compreende ao mesmo tempo a concepção (projeto, programa, manifesto normativo) e a produção (composição, realização da escritura) da obra de arte. ○ conceito é válido não só para a poesia, mas também para todas as artes. Tudo que envolve o trabalho de um artista da poíesis é sua poética artística, aquela que configura a linguagem. Já os artistas da práxis são atores e diretores teatrais, bailarinos, instrumentistas, cantores e maestros, entre outros. De um modo geral, na história das artes, a maior parte dos artistas só atua na práxis e a maior parte dos artistas da poíesis atua também na práxis. $\bigcirc$ conhecimento da poíesis (daí lógos poético) é essencial para o profissional da práxis, porque precisa entender da linguagem de cada poética artística, para poder interpretá-la (exercício hermenêutico), tendo em vista os limites da interpretação, não obstante sua incontornável idiossincrasia,

\section{5}

REV. TULHA, RIBEIRÃO PRETO, v. 7, n. I pp. 236-392, jan.-jun. 2021 
e para executá-la de modo dinâmico com seu próprio corpo (daí lógos corpóreo).

É importante que seja reconhecido o modo como esses profissionais podem e devem atuar. Contudo, ao longo dos anos, praticamente dos anos 60 até aos anos 90, a Pós-Graduação Profissional foi preterida, com raros exercícios de poíesis e práxis nas universidades públicas. Na tentativa de elaborar um projeto de um novo programa de PósGraduação Profissional, por várias vezes, eu mesmo ouvi aqui na USP dos colegas das instâncias superiores: "não, Rubens, isso não presta, a Pós-Graduação Profissional não pega bem, a acadêmica que é a boa, que é a cara da USP". Instituiu-se esse preconceito, esse desdém, como se os conhecimentos prático-poéticos fossem inferiores. Em relação a um curso, por exemplo, de arte ou de Educação Física, que tem no mérito profissional o seu carro-chefe, chega a ser contraditório o fato de essas atividades não serem devidamente valorizadas.

\section{Falas iniciais}

\section{2)Prof. Dr. Aloysio Fagerlande (UFRJ)}

Leio um trecho de uma entrevista que saiu no Jornal Zero Hora, em 2012, em Porto Alegre, de um professor de escrita criativa, Prof. Charles Kiefer:

"Sou professor universitário e escritor e, como acadêmico escritor, vivo uma situação patética para não dizer hilária. Escrevo um romance que me toma anos de pesquisa, anos de trabalho para redigi-lo. Não faço citações, não transcrevo textos alheios. Minha bibliografia é o conjunto de obras que fui capaz de ler ao longo de toda a minha vida, somado aos filmes que vi, às músicas que ouvi, às experiências que vivi. Como sou professor universitário e de Pós-Graduação em Escrita Criativa, vivo acossado pelo que se conhece por produção acadêmica, dados que precisam ser lançados no Currículo Lattes, porque, se eu não obtiver uma determinada pontuação, serei descredenciado. Meu curso, no caso, a Faculdade de Letras, será prejudicado no ranking nacional das Universidades brasileiras. Meu romance, tão demorado e pacientemente elaborado, - alguns me tomam 4 ou 5 anos de trabalho, atividade em que eu apliquei engenho e arte, em que procurei o que 
a crítica literária chama de tour de force - não vale praticamente nada como produção acadêmica. Depois que publiquei o romance, vivo uma situação verdadeiramente kafkiana. Um aluno faz um ensaio de algumas páginas sobre meu romance, publica as suas considerações numa revista de Qualis A e recebe uma pontuação maior que a minha em termos de produção acadêmica."

A fala ilustra bem esse dilema por que nós passamos. Por exemplo, menciono, modestamente, os CD's que eu venho produzindo. São CD's meus de músicas de câmara, em que atuo como solista. Dois deles foram realizados por meio do Edital Petrobrás; três, por meio da FAPERJ. Na época em que ainda havia dinheiro, havia esses editais. Três deles foram lançados com apoio da FAPERJ, sendo que o primeiro foi num APQ3, que é de produção editorial. A FAPERJ, já em 2012, reconhecia o CD autoral equivalente a um livro. Ou seja, havia um mesmo edital para livros e CD’s. Além disso, há dois anos, implantamos um curso de Pós-Graduação Profissional em Música na UFRJ. Há, portanto, espaço para os dois tipos de Pós-Graduação.

Na implantação do curso, uma das disciplinas que sempre se pensa existir na Pós-Craduação é a Metodologia. Sempre estudamos, em qualquer área, a Metodologia da Pesquisa Científica. Porém, isso se aplica na arte, na subárea de Música? Eu me lembro de uma das primeiras orientandas, no Mestrado, que quase chegou chorando, dizendo: - "professor, a professora, que dava pesquisa, disse que meu trabalho não tem uma questão". Por um lado, não havia, no trabalho, um princípio da pesquisa científica; por outro lado, o trabalho dela, antes de estar pronto, já tinha convite para ser publicado na China e no Canadá. Ou seja, um trabalho sem questão já tinha conseguido uma dimensão internacional que a nossa Pós-Graduação tanto almeja.

Assim, comecei a pesquisar como era feita a pesquisa em artes na Europa e nos Estados Unidos. Encontrei um professor da Universidade de Leiden, Henk Borgdorff, que, em 2012 , lançou uma compilação de artigos e palestras chamadas de The Conflict of the Faculties: Perspectives on Artistic Research and Academia. $\bigcirc$ título parodia Immanuel Kant, quanto ao conflito das faculdades, à questão das Faculdades superiores e inferiores, ou seja, aquela luta clássica, no final do século XVIII, no qual a Teologia e o Direito estão contra as outras "humanidades". Ele coloca muito bem a questão da transformação das práticas artísticas em pesquisa artística e a consequente modificação da academia em um

\section{7}

REV. TULHA, RIBEIRÃO PRETO, v. 7, n. 1 pp. 236-392, jan.-jun. 2021 
local que também proporcione espaço para as formas de conhecimento não discursivos, métodos de pesquisa não tradicionais, além de novos formatos de apresentação e publicação. Ele aponta, basicamente, três tipos básicos de pesquisa:

1) A primeira pesquisa sobre as artes, que ele chama de Research on the Arts, é baseada em uma pesquisa sobre a prática artística a partir de um distanciamento teórico com o pesquisador observando o objeto de pesquisa. São os casos clássicos da Musicologia, História da Arte, Teatro, Literatura, em que o pesquisador olha o objeto com certo distanciamento.

2) $O$ segundo tipo seria a pesquisa para as artes (Research for the Arts), em que elas não constituem o objeto de pesquisa, mas o objetivo, produzindo insights e instrumentos para práticas mais concretas, trazendo a uma área bem específica (por exemplo, fagote, instrumento de palheta dupla, como oboé, que poderia gerar um estudo sobre a confecção de palhetas, tipos de raspagem para se tocar oboé ou fagote). Isso seria um caso clássico de pesquisa para as artes que pode gerar um método. Por exemplo, foi feito um estudo sobre excertos orquestrais para trompa, o primeiro volume sobre a série dos choros de Villa-Lobos. No palco, um trompetista com mais de 30 anos de experiência profissional, professor ainda sem Mestrado, fez um trabalho fantástico, que é um método, no qual ele aponta os principais solos e excertos para trompa dentro dos choros de VillaLobos, com observações interpretativas. Produziu, também, um vídeo para cada trecho, mostrando como ele toca. Isso seria um exemplo da pesquisa para as artes.

3) $\bigcirc$ terceiro tipo seria a pesquisa nas artes (Research in the Arts). Borgdorff descreve o processo como imanente, constituindo uma pesquisa que não assume a separação entre sujeito e objeto, não existindo, portanto, a separação entre pesquisador e prática das artes, entre a teoria e a prática em artes. $\bigcirc$ autor entende que os conceitos e as teorias, as experiências e os entendimentos estão entrelaçados com as práticas artísticas. Desse modo, a arte é sempre reflexiva, embora ele ressalte que essa tricotomia apresentada é apenas um modelo de estudo, pois existem diversas possibilidades, que, basicamente, encaixam nessas três.

\section{8}

REV. TULHA, RIBEIRÃO PRETO, v. 7, n. I pp. 236-392, jan.-jun. 2021 
Ele cita diversos exemplos que aconteceram na Europa, entre as quais, a Practice as Research, que expressa diretamente o entrelaçamento de pesquisa e prática como exposto acima. Ademais, houve um número da ARJ (Arts Research Journal), que é uma revista da CAPES, interdisciplinar, que envolve várias subáreas da área de artes, sobre conceituações de pesquisa em artes. Uma das autoras, belga, também vinculada ao grupo do Borgdorff, fala que, na pesquisa em artes, há uma possivel visão binocular, que é o primeiro caso que o Borgdorff cita em que existe um distanciamento entre o pesquisador e o objeto e uma visão prismática, ou seja, com vários ângulos, dependendo da posição em que o pesquisador se encontra. A autora é um pouco mais abrangente do que o Borgdorff, mas se expressa dentro dessa mesma perspectiva.

Há, portanto, projetos fantásticos acontecendo, sobretudo na Grã-Bretanha e nos países nórdicos da Europa, Holanda e Austrália, que ele chama de Practice as Research in the Arts. Essas questões surgiram na Europa, sobretudo após a declaração de Bologna, em 1999, porque, até então, havia os conservatórios e as escolas superiores de arte de um lado; do outro, as universidades, com outras necessidades e saberes. Por conseguinte, a delimitação do conhecimento estava bem separada. A universidade fazia pesquisa e os conservatórios e as escolas superiores de arte faziam artes. A partir dessa qualificação do sistema educacional europeu, houve a necessidade de fusão. Logo, começou o dilema: a Universidade deveria aceitar a arte, e as antigas escolas (conservatórios, academias e escolas superiores) também tiveram que absorver o modelo universitário. Eles encontraram alguns caminhos: por exemplo, no Conservatório Nacional Superior de Música de Paris, $3^{\circ}$ ciclo, que seria equivalente ao Doutorado, tem um acordo com a Sorbonne, para eles fazerem algumas disciplinas de musicologia na universidade. Porém, pelo que eu ouço de colegas, a experiência não está dando muito certo, porque poucas pessoas estão realmente fazendo esse acordo com a Sorbonne. Já o $2^{\circ}$ ciclo, que seria equivalente ao nosso Mestrado, praticamente foi incorporado ao $1^{\circ}$ ciclo, que seria nossa Graduação. No panorama europeu, praticamente ○ $2^{\circ}$ ciclo em arte virou um Mestrado Profissional, isto é, equivalente ao que nós chamamos de Mestrado Profissional aqui. Há uma grande confusão sendo montada, com várias pessoas estudando essa questão da pesquisa em artes na Europa e ainda sem uma resposta. Nesse sentido, existem propostas muito interessantes. 
Para chegar também ao polo oposto, que são os Estados Unidos, a Pós-Graduação em Música é regida pela National Association of Schools of Music (NASM). Ela envolve cerca de 670 instituições, entre escolas independentes, escolas e universidades em várias denominações. Cito dois exemplos clássicos que não aderiram ao sistema universitário: a The Juilliard School, em Nova York, e a New England Conservatory of Music, que são instituições de excelência no mundo todo. Se procurarmos sobre conservatório, nove entre dez papers abordam um caráter pejorativo do termo conservatório. A New England, por exemplo, demonstra que não é bem assim.

Os Estados Unidos publicam um manual de 2 em 2 anos. $\bigcirc$ manual de 2017/2018 tem cerca de 280 páginas. Só de Master's Degree, há oito tipos somente da parte de performance. Igualmente ocorre com - Doutorado. Desde a década de 30, se não me engano, os Estados Unidos têm essa convivência entre os dois sistemas. Há a convivência dos diversos títulos e o que encontramos do Master's Music, Master's Music and Arts, Doctor. Há umas dez possiveis titulações a partir dessas especificações.

No panorama brasileiro, a partir de 65, o Prof. Newton Sucupira estabelece dois modelos: a Pós-Graduação Profissional e a Acadêmica. Porém, 30 anos se passaram e a Pós-Graduação Profissional não foi efetivada. Recentemente, a Pós-Graduação Profissional em Música na Bahia foi o primeiro curso, há uns cinco anos. Depois, a UNIRIO e a UFRJ, há 3 anos. Nós formamos a primeira turma e agora estamos com a terceira turma. Vamos abrir o quarto processo seletivo.

Se observarmos todas as especificidades da Pós-Graduação estadunidense, encontramos uns dez tipos de titulação diferentes. Aqui todas elas estão englobadas. A Profa. Elisa Maria Tiago, da Diretoria de Avaliação da CAPES, apresentou uma questão da pesquisa básica em que ela cita o modelo do Bohr. Trata-se de pesquisa básica por busca do avanço do conhecimento sem compromisso com aplicação imediata. Os dois tipos de pesquisa que teriam aplicabilidade prática seriam a pesquisa estratégica, como ela cita Lee Pasteur, que acrescenta conhecimento como ferramenta para solução de problemas práticos, e a pesquisa lógica, citando Thomas Alva Edison, que desenvolve aplicações para conhecimentos básicos ou estratégicos já existentes. A nossa Pós-Graduação Profissional enfrenta vários dilemas, como a questão da avaliação. 
A questão que eu queria salientar é a produção intelectual, que significa produção bibliográfica, artística e técnica. No caso dos programas acadêmicos, a recomendação dos avaliadores era considerar a distribuição de produção bibliográfica, levando-se em conta que a produção artística não libera o docente permanente de programa de Pós-Graduação Acadêmico de produção bibliográfica. É diferente na avaliação dos profissionais. Observando por alto, há uma incipiência de dados para avaliar um programa profissional, sobretudo em artes. Nós estamos indo, agora, para avaliação das APCN 2017/20 18 na área de artes, em que se avaliará, pela primeira vez, a modalidade Doutorado Profissional. Não há parâmetros definidos para a área. Há uma recomendação geral que um grupo de trabalho fez para todas as áreas. Ou seja, o que se espera? Essas respostas devem vir da área. Nós é que precisamos construir esse cenário.

Isso foi uma visão "micro" em cima de uma questão específica. Agora, em uma visão "macro" sobre a Pós-Graduação e a educação brasileira como um todo, hoje em dia, um dos grandes filões ainda inexplorados para investimento é a educação no Brasil. Prova disso é que o maior milionário que consta na Revista Forbes do Brasil está aplicando, no Rio de Janeiro, em escolas de Ensino Médio e, provavelmente, universidades. Em um parecer do Conselho Nacional de Educação, que saiu no Diário Oficial da União, no final de 2017, o assunto eram normas referentes à Pós-Graduação stricto sensu no país. Ressalto uma parte que eu achei muito significativa: "as instituições credenciadas para oferta de cursos a distância poderão propor programas de Mestrado e Doutorado nesta modalidade".

Temos Educação a Distância, que funciona bem (mas não para o curso todo). Esse parecer avaliza e institucionaliza os programas de Pós-Graduação stricto sensu a distância. Há um mês, numa revista de bordo, encontro um anúncio da Manchester University, Universidade a distância, a Universidade americana para brasileiros, cujo Reitor é um dos signatários deste documento do Conselho Nacional de Educação. 
Assim como os professores Marcelo e Ferdinando Martins, o Prof. Antônio Araújo e eu participamos de um grupo de pesquisa chamado "Laboratório de Práticas Performativas". Estou falando de alguém que pesquisa teatro e a interface com a performance, especificamente, com a arte da performance. Ela, em termos gerais, é desvalorizada na Universidade. A ideia de um professor artista na Universidade de São Paulo ainda é uma ideia menor em relação ao dito professor acadêmico. Na realidade em que estamos vivendo, a desconsideração dessas capacidades especíificas e de saberes específicos na área de artes está em vários niveis e em todas as instâncias na Graduação, na Extensão, na Pesquisa, na contratação de professores.

Tanto eu como o Prof. Araújo, para trabalharmos em um espetáculo de teatro, nossos dois grupos trabalham mais ou menos dois anos para produzir um espetáculo. Eles estão calcados numa pesquisa, ou seja, não é simplesmente fazer uma atividade. Há uma pesquisa que leva anos, e leva mais de um ano para ser trabalhada. Esse espetáculo vale, provavelmente, menos que um artigo de meu orientando. Nós vemos o mesmo disparate de consideração em relação à força e hora de trabalho em função da atividade. Isso acontece da mesma forma com um romance, com os espetáculos etc. Na penúltima reunião de Pós-Graduação, novamente eu fui informado, no programa de PósGraduação em Artes Cênicas, de que a CAPES não apoiaria a ida de um professor num festival internacional de teatro, que era o meu caso, porque não seria um festival acadêmico. $\bigcirc$ Qualis artístico, que demorou anos (desde o final de 99, estamos batalhando para esse Qualis), significa que, quando sou convidado para um festival internacional de teatro, trago à minha Pós-Graduação um Al. Porém, a minha Universidade não me apoia para eu ir a este festival. Eu trago reconhecimento, eu trago a pontuação Al, mas eu não tenho apoio porque o que se coloca na nossa cultura interna é que "a CAPES prioriza e apoiará somente os encontros acadêmicos". Meu orientando, se fizesse uma resenha sobre - que eu apresentaria, poderia ir, mas não o meu trabalho que passou dois anos para ser feito. Isso é completamente absurdo. Eu ainda estou pesquisando se a CAPES realmente faz isso. A representante da CAPES pode falar, mas o que existe na cultura interna da USP é essa, porque há uma diferença entre o que existe na lei e o que existe na cultura interna da instituição. 
Na nossa cultura interna, há uma desconsideração do saber artístico. Ficamos constrangidos para falar que temos que sair para apresentar um trabalho. É quase como se fosse alguma coisa menor do que quando um professor sai para um congresso científico. Essa palavra "científico-acadêmico" é utilizada para oprimir, na verdade, para desvalorizar os outros saberes, no caso, o saber artístico. Quanto à atual situação da Universidade de corte de verbas, é possível fazer uma comparação. Nesse desmonte que nós vivemos, do ponto de vista financeiro, o desmonte na área de artes é muito mais grave, é muito maior. No nosso caso, nas artes cênicas, nós temos uma escola técnica que funciona à noite, no mesmo prédio. Temos a Universidade construindo vários prédios. Porém, há anos, temos duas escolas na área de artes cênicas, uma amontoada sobre a outra, uma defasagem terrivel em que uma escola não consegue fazer extensão e nem pesquisa à noite, porque eu tenho que ceder minha sala para uma outra escola que funciona. $\bigcirc$ problema é das duas escolas? Não. $\bigcirc$ problema é que a Universidade não considera um valor dar um espaço adequado à Escola de Arte Dramática, por exemplo. $\bigcirc$ mesmo fenômeno acontece na questão das verbas. Apenas durante um único período (estou aqui há dez anos), houve um edital realmente com verba para área de extensão, que é um outro campo também desprezado - a extensão em artes, com exceção daquilo que são aqueles órgãos raríssimos no caso do TUSP, talvez a orquestra sinfônica. Algumas coisas muito pontuais recebem verba para isso, mas não há editais gerais para projetos de extensão na área de arte com verba. Ou seja, esse desprezo pela extensão em artes é estarrecedor aqui na Universidade. Isso é uma questão sobre a qual precisa discutir: qual é a função da extensão da USP? Inclusive, se comparar as verbas que são utilizadas para extensão na área de saúde, por exemplo, e na área de artes, nós temos um disparate também. Do ponto de vista da Graduação (já comentei a questão da contratação de professores), os critérios, no caso da contratação de professores na área de artes, deveriam ser revistos, porque na vaga de direção teatral, por exemplo, a pontuação para trabalhos acadêmicos vale mais do que a pontuação para os espetáculos que eu fiz. Porém, eu vou dar aula de direção teatral, que é um saber prático. Não adianta ficar fazendo artigos sobre direção teatral se não for um diretor teatral. Como ensinará? Igualmente com a área de cirurgia: como se faz um concurso se 20 anos de cirurgia valem menos do que uma pessoa que apresentou trabalhos acadêmicos? Essa situação, no caso da USP, com o atual desmonte de verbas, está cada vez mais grave. Precisamos rever esses pontos. Nós tínhamos, por exemplo, uma bienal de teatro promovida

\section{3}

REV. TULHA, RIBEIRÃO PRETO, v. 7, n. I pp. 236-392, jan.-jun. 2021 
pelo TUSP, que não aconteceu no ano passado por conta da falta de verba. Sabemos, no entanto, que há verba para outros eventos. Uma bienal de teatro na USP não tem valor para a atual administração.

Nosso Departamento de Artes Cênicas tem vários grupos de pesquisa, que não conseguem ter verba para pesquisa. Esses grupos não conseguem nem ter espaço para pesquisar porque nós temos que dividir o prédio. Além disso, a verba que um departamento de arte recebe por ano é pífia em relação à demanda. Para se ter uma ideia, no ano passado, foram mais de 24 produções, trabalhos práticos produzidos e apresentados à comunidade, tanto de trabalho de conclusão de curso, como também trabalhos de extensão e de disciplinas. Mais de 24 produções foram apresentadas à comunidade, sem nenhuma verba da Universidade envolvida nisso. De uma forma geral, a tradição de Extensão, de Pesquisa e de Graduação é de desvalorizar o saber em arte. A construção do conhecimento na área de artes precisa ser ressignificada, redimensionada. Precisamos pensar juntos em estratégias para mudar essa realidade.

34)Prof. Dr. Rubens Russomanno Ricciardi (FFCLRP)

A música sem o teatro não se consolida como um projeto artístico, assim como o teatro também, sem a música. Logo, essa colaboração próxima, estreita entre as áreas, é essencial. Costaria de reforçar que não é o caso de usarmos a palavra "outros saberes". Afinal, esses são os saberes essenciais, não são nem outros saberes. Nós temos que valorizar os saberes essenciais, que é, também, o saber prático-poético, o saber da práxis e da poíesis.

35)Prof. Dr. Euclydes Fontegno Marques (FM)

Na minha área, embora bem diversa, a problemática é mais ou menos a mesma. Eu sou um discípulo do Prof. Zerbini, que conseguiu conciliar o valor e a atividade prática com a parte acadêmica. Ele 
pensava mais ou menos assim: se tem que mostrar esses títulos, vamos mostrá-los, mas é importante valorizar a parte prática.

Em uma época, ele quis que eu fizesse uma tese de Doutorado. Eu disse: "professor, eu não tenho material". Ele disse: "você vive entrando no pronto-socorro, fazendo reimplantes de membro, pendurando braços lá de Fulano... faça uma tese com isso". Eu disse: "Mas Professor, está tudo mal estudado, há casos que não têm fotografia, outros não têm segmento, não sei se dá uma tese". Então o Prof. Zerbini interrompeu-me e disse: "Olha rapaz, tese é social, tese é para você ir lá de beca na frente e falar aquilo tudo, depois batem palma, a familia fica feliz e te abraça, se depois desse material você não publicar, não divulgar e não ensinar para os outros, aquilo não vale nada, mas você tem que fazer Doutorado, vai lá e pegue isso". Eu tive que fazer o Doutorado. Ele possuía um sentido muito prático das coisas, mas ele seguia o padrão universitário, porque ele achava que era mais fácil assim.

Em outro exemplo, houve um professor que não tinha doutorado, não tinha Mestrado e não tinha livre-docência: chamava-se Nagib Cury. Ele formou dezenas de cirurgiões, práticos, ele fez residência na América do Norte, ele ficou oito anos lá e voltou e ficou no grupo do Zerbini. Nagib era o chefe do grupo de pulmão e, no começo, operava muito coração também. Naquele tempo, nos anos 50 e poucos, o estreitamento da válvula mitral era operado enfiando o dedo dentro do coração e dilatando a válvula com o dedo. Não havia a possibilidade de abrir tudo a céu aberto e parar o coração. Não havia máquina nenhuma: enfiava o dedo no coração e dilatava a válvula. $\bigcirc$ Prof. Nagib me ensinou a fazer isso. Eu fui o último que aprendeu a fazer isso, porque acabou essa operação, começou a se operar a céu aberto, abrir o coração e ver lá dentro. Mas às cegas, eu fui o último que aprendeu isso, em São Paulo. Então Nagib fazia assim: abria os doentes, fazia uma "suturinha" em volta do coração, punha o dedo dentro do coração, explorava tudo. Ele dizia: “agora você põe o dedo". Eu punha o dedo. "Vai correndo o dedo bem na parte posterior". Eu ia fazendo. "Sentiu um buraco aí?" Senti. "É a veia pulmonar esquerda; desce um pouquinho para dentro que você vai sentir a válvula". Eu sentia batendo no meu dedo. Ele me ensinava como explorar a válvula. "Teu dedo passa dentro?". "Não passa". "Força um pouquinho". Eu forçava. "Abriu”. Ele: "para”. Eu tirava, e ele punha o dedo: "é, você conseguiu abrir um pouco a válvula, mas a comissura posterior ainda está fechada, põe o dedo de novo". Eu punha o dedo. Assim, trocávamos o dedo dentro do coração umas

\section{5}

REV. TULHA, RIBEIRÃO PRETO, v. 7, n. 1 pp. 236-392, jan.-jun. 2021 
10 vezes até eu conseguir abrir a válvula sem prejuízo para o doente, porque, a cada milímetro, ele conferia se estava certo.

Eu nunca mais vi isso na minha vida. $\bigcirc$ cirurgião aprende ajudando o mais velho, tentando ver tudo que ele pode. No dia em que ele puder fazer sozinho, ele vai fazer, levar pela mão, ensinar passo a passo, conferir o que o outro faz. Isso é professor de cirurgia.

Eu só conheci um: Nagib. Nunca vi outro. Esse homem formou dezenas de cirurgiões, não era docente, nem catedrático. Ele era um professor com P maiúsculo. Além disso, era um homem muito humilde. Ele dizia a um enfermeiro: "olha, está vendo o frasco de drenar o tórax? Eu vou te ensinar como é que você põe a rolha nele". Ele ensinava desde o mais humilde auxiliar de enfermagem até os residentes que estavam à frente.

Este é o ensino prático. Nós temos que ter a parte acadêmica, mas não podemos desprezar a habilidade prática, essa qualidade que alguns têm de passar conhecimento prático para frente. $\bigcirc$ Prof. Nagib (nesse ponto ele até exagerava um pouco), depois que dava uma aula como convidado e ganhava um "diplominha”, questionava-se: "para que serve isso?" Não na frente dos outros, para não ofender, ele pegava o "diplominha" no bolso, rasgava-o e jogava-o no cesto. $\bigcirc$ pessoal coleciona esses "diplominhas" porque isso engrossa o currículo. Fulano põe dezenas de aulas que ele deu "aqui, lá, não sei aonde", e os currículos são avaliados pela grossura em centímetros. $\bigcirc$ Prof. Nagib, se fosse disputar alguma coisa, não tinha currículo nenhum, porque ele nem guardava os documentos, os títulos que ele poderia ter.

Claro, exagerou um pouco porque isso atrapalha a carreira. $\bigcirc$ exemplo deseja mostrar como existe essa atividade prática e como ela é importante na Universidade, porque, na minha área, o importante da Universidade, além de formar cientistas, é formar profissionais práticos, que curarão doentes. São necessários os pesquisadores também, mas é minoria. A maioria formada é médico prático, médico que cura doente. Alguns farão descobertas, o progresso da ciência, mas não podemos descuidar da formação do profissional prático. 


\section{6) Prof. Dr. Wilson Roberto Navega Lodi (FMRP)}

Quando o Prof. Rubens Ricciardi me convidou para participar dessa mesa redonda, fiquei em dúvida se deveria aceitar, afinal, o que um ex-professor de Bioquímica da Faculdade de Medicina de Ribeirão Preto, aposentado compulsoriamente há quase uma década, poderia contribuir ao debate atual sobre a valorização da atividade profissional dentro da USP e mesmo no país?

A situação atual, evidentemente, é grave, principalmente dentro das escolas menos prestigiosas. Algo precisa ser feito. Mas será que a Pós-Craduação Profissional resolverá o nosso problema principal? A importância da Escola de Pós-Graduação americana é inquestionável. $\checkmark$ Banco de Boston relata que os egressos do MIT (Massachusetts Institute of Technology) foram responsáveis pela criação de quatro mil indústrias capazes de definir o que seria o $24^{\circ} \mathrm{PIB}$ do mundo. Se adicionarmos os PhDs egressos do Caltech, da Harvard e de Berkeley, que, no ano de 2004, totalizaram pouco mais de 1000 PhDs, e, em passe de mágica, retirássemos todos eles do país, os Estados Unidos da América deixariam de ser o país que conhecemos hoje. Pois bem, nesse mesmo ano, a USP formou 2180 PhDs; a UNICAMP, 747; a UNESP, 663; a UFRJ, 643, de acordo com Brito Cruz. Durante muito tempo, ele trabalhou na FAPESP e apresentou esses dados em um seminário do IEA de Ensino Superior. Esses números brasileiros são cerca de quatro vezes maiores que os número de formados em suas congêneres americanas que eu citei, das quatro que eu tinha citado. Olhando esses números, estaríamos bem? Será mesmo? Nos Estados Unidos, um aluno no final do seu segundo ano da escola de Pós-Graduação, depois de terminados os cursos formais, realiza o seu exame de qualificação, propondo um projeto de tese para uma banca externa. Nos melhores lugares, ele precisa ter, nesse projeto, o potencial de fazer ciência. Fazer ciência ocorre somente em duas condições: primeiro, em criar um novo problema na área, que ninguém, nem mesmo o proponente, imaginaria como solucionar; segundo, em resolver um daqueles problemas existentes na especialidade, mas isso de uma maneira não prevista pela comunidade.

Esse ambiente extremamente exigente motivou a realização de um filme, há uns 20 anos, chamado The Graduate, traduzido para o português como A primeira noite de um homem. Na verdade, não importa que poucos desses projetos se concretizem integralmente, a 
tese poderá ser muito menos ambiciosa, isso é irrelevante, o importante é a disposição de se engajar nesse tipo de empreitada. Entre nós, depois que foi publicada a lista dos improdutivos da USP em 1988, nem os alunos e nem seus mestres sonham com algo parecido: o objetivo passou a ser extremamente "prático", quantos papers renderá esse projeto? Ele me habilitará a conseguir uma posição em um concurso qualquer? Se este é, em essência, o problema dos doutoramentos na área de ciência no Brasil, como ele se apresenta na Medicina, na Música e em tantas outras escolas profissionais? Venho da Faculdade de Medicina de Ribeirão Preto: sou médico também, uma das únicas do país com Escola Paulista de Medicina a manter os departamentos da área básica na sua estrutura; as outras escolas expulsaram a área básica, que passaram a constituir institutos separados da Faculdade de Medicina.

Nos Estados Unidos, todas as escolas médicas também mantêm a sua área básica. Elas, em conjunto com a Escola de Pós-Graduação do campus (há uma Escola de Pós-Graduação em cada campus), estão autorizadas a formar seus PhDs em Bioquímica, em Fisiologia, Farmacologia, em Imunologia, as áreas básicas da Faculdade de Medicina. Por outro lado, não existe, ao que eu saiba, nenhum curso de Pós-Graduação nos principais departamentos clínicos das escolas médicas estadunidenses, não há nenhum curso de Pós-Graduação em clínica médica nessas escolas, nenhum. Entretanto, após a "reforma universitária" do ex-Ministro Jarbas Passarinho (1969-74), todas as escolas profissionais passaram a exigir uma Pós-Graduação, e o pior, incluindo ainda a exigência do título de Doutor para o ingresso na carreira docente. Esse são equívocos graves, infelizmente, existentes em grau maior ou menor em todas as escolas profissionais do país.

Para terminar, contarei a história de um dos nossos alunos de Bioquímica que, depois de terminar o seu Mestrado, escreveu para um famoso cientista do Instituto Nacional de Saúde procurando um estágio. $\bigcirc$ americano respondeu que, assim que terminasse o seu PhD, o procurasse. Ao contar para o seu orientador brasileiro a história, o nosso mestre sorriv e disse a ele: "você esqueceu de dizer que também já era médico (ele era médico e estava fazendo Mestrado), porque o NIH aceita somente médico ou PhD, considerados, por eles, como possuidores da formação científica adequada para frequentar o Instituto. Até então, o nosso aluno acreditava que o Mestrado em Bioquímica era o título mais importante que possuía. 
Obrigado pelo convite para tratar de um assunto tão delicado e tão importante. A minha formação é em Engenharia, por isso falarei sobre o caso da Engenharia. Antes, eu queria fazer uma observação: esse assunto é extremamente importante para a Universidade, mas ele transcende um pouco a questão de Mestrados ou graus profissionalizantes. Para tentar resolver esse problema da base, tem que saber qual é a sua missão, que precisa abranger todo o arco do conhecimento, desde o puramente racional até o mais transcendental.

As universidades começaram pelo avesso: a área transcendental era um fenômeno religioso, e hoje ela começa pelo outro lado. Então a consideração desse arco do conhecimento, fazendo parte importante da nossa existência e, principalmente, da formação das nossas novas gerações, é essencial. Eliminar a arte é como que cortar uma parte do nosso conhecimento e da potencialidade dos nossos estudantes. Precisamos pensar, também, nos estudantes, não somente "formar", considerando o sistema de Mestrado, Doutorado etc. Uma das funções da Universidade é formar novas gerações. Essa formação não pode ser castrada. Ela tem que reconhecer desde a parte de artes até a parte puramente racional, como a Matemática pura, porque isso se pode demonstrar. Por exemplo, se eu entendo e explico o teorema de Pitágoras para o meu semelhante, ele entenderá igual a mim; agora, uma obra musical, ele não entenderá igual a mim, mas tem o seu valor também. Esse é um ponto que precisa ser agregado e precisa ser muito discutido na Universidade.

Em um exemplo mais relacionado à área de Ciências da Natureza, portanto um extremo mais racional, em uma de suas conferências, na segunda ou terceira aula, um professor dizia o seguinte: "bom, eu vou tratar, hoje, de um assunto que eu costumo oferecer para os meus estudantes de Doutorado, já os mais adiantados, e a minha missão é manter vocês aqui, porque senão, daqui a pouco, vai todo mundo embora da audiência, e eu quero falar para vocês, por isso eu quero dizer o seguinte: não fiquem preocupados se vocês não entenderem porque os meus alunos do Doutorado também não entendem. Agora, vocês sabem por que não entendem? Porque eu não entendo. E sabe, ninguém entende, mas funciona". Então é essa questão racional. Em 
seguida, começa haver a parte da intuição: uma série de outros fatores que fazem parte da nossa existência e da nossa ação também.

Sobre o outro ponto, o que vale no Brasil é o diploma, não a competência. Uma das razões por que acontece essa barbaridade é devido a querer ter o diploma. Assim, precisam ter 2000, 3000, 4000 mestres, doutores, porque o diploma de doutor é o que vale. $\bigcirc$ que aquilo representa é outra coisa. Trata-se de uma questão cultural que precisa ser resolvida também. Isso significa não apenas ter cursos de Doutorado mais valorizados, mas não desvalorizar as outras competências. Um curso de Instituto Técnico de Engenharia, como o Paula Souza, em São Paulo, é excelente, mas a sua função na sociedade é outra. É preciso, portanto, que se reconheçam as competências em suas devidas proporções.

$\bigcirc$ meu curso de Engenharia foi extremamente profissionalizante. Embora eu não tivesse um doutor na minha formação, nós éramos excelentes engenheiros. Fazíamos o curso com a parte mais básica. Depois do terceiro ano, nos últimos três anos, eram cursos profissionalizantes. Com a instituição da Pós-Graduação, isso começou a se alterar, começaram a ter valorização de Mestrado, de Doutorado, o tipo de formação mudou para o outro lado. Nos cursos de Engenharias, não se aprende sobre pontes lendo no livro, mas aprende-se fazendo. Um professor de pontes, se quisermos formar um bom engenheiro civil, deve trabalhar na área. Porém, para trabalhar na área, não pode ser em tempo integral, com dedicação exclusiva. Ele teria que ser um professor de tempo parcial, um conferencista. A Universidade, hoje, rejeita essas pessoas. Isso não dará um bom resultado. É preciso que haja bons profissionais, quem faz máquinas, órgãos de máquinas, projeto de automóvel. Isso não se aprende em um laboratório, é preciso ser um profissional. Que haja, portanto, a volta desses grandes profissionais, como existiram grandes aqui na USP.

Na Pós-Graduação, nas Engenharias, isso fica um pouco nebuloso, porque há muitos cursos, muitos diplomas e teses que se aprovam como sendo um Doutorado Acadêmico, e não é acadêmico apenas, é a nossa experiência. Eu falo um pouco da nossa experiência na COPPE, no Rio de Janeiro, nas Engenharias. Um grande motor da Pós-Graduação das Engenharias, principalmente civil, mecânica e elétrica, até nos anos 70 ou 80, foi a Petrobrás, foi a descoberta de petróleo no fundo do mar. Não existia país no mundo que tinha esse problema. Isso era um 
problema brasileiro, que tinha que ser resolvido por brasileiros. As teses eram orientadas para resolver esses problemas que não existiam em outro lugar. Havia uma grande dose de originalidade. Se não se encontra em livro, como é que se resolve isso? Ou resolve ou não tem solução. Depois aconteceu o pré-sal, que era, também, outro problema que só existia aqui. Agora já encontraram em outros lugares. A perfuração do pré-sal foi desenvolvida aqui, com teses sob essa vertente também profissional. Eram soluções de problemas extremamente complexos, não se encontravam em lugar nenhum, de modo que fica um pouco essa questão: até que ponto a Engenharia é profissionalizante? Apesar de existir uma certa tendência de haver alguns Mestrados e Doutorados profissionalizantes, o que se entende disso, na Engenharia atual, é como uma resposta a uma demanda industrial. Em Santa Catarina, por exemplo, que é uma Universidade com foco bastante integrado com o setor industrial, existem demandas da indústria que são problemas mais complicados, não são grandes descobertas, mas exigem criatividade etc., então trabalham em conjunto.

Na UFABC, está sendo implementado um Doutorado profissionalizante (que acho bem interessante): o estudante recebe em acordo com uma empresa. É muito difícil, nas Engenharias, fazer um Mestrado nessa categoria profissionalizante, se não houver o setor produtivo envolvido. Uma Universidade ou uma determinada indústria tem uma dificuldade em um certo problema ou quer desenvolver novas técnicas. $\bigcirc$ estudante ou o candidato fica seis meses nessa empresa, sem tema definido, estudando com os engenheiros quais são os temas que eles precisam resolver e que dariam uma tese. Quando isso é encontrado, os dois fazem essa conexão, logo é uma tese profissionalizante no sentido muito bom, porque é resolver um problema novo que interessa ao setor industrial, quer dizer, ela não é gerada internamente na Universidade, mas em conexão com setores industriais. Um pouco é a Medicina: qual é o doente, vamos ver como é essa doença, se há soluções para ela. Não é um hospital único, mas são várias seções de hospitais em várias universidades. Isso tem muita chance de dar um bom resultado, e já há resultados bastante interessantes.

Quanto à formação dos nossos estudantes, acoplada com toda a formalização da Pós-Graduação, está acontecendo um exagero na categorização ou na aprovação de cursos de Mestrado e Doutorado em quantidade de trabalhos. Isso está matando várias vocações. Menciono um caso que aconteceu na UFABC: eu estava como Reitor naquela 
época, então eu participava de todas as bancas porque queria dizer aos candidatos o que eles encontrariam, porque é uma Universidade com outro projeto. Em uma delas (era banca de neurociências), havia cerca de 15 candidatos para quatro ou cinco vagas. Todos fizeram as suas apresentações de trabalho de tese. Uma das candidatas fez uma exposição bastante interessante, mas ela terminou dizendo que não era isso que queria fazer. Os examinadores focalizaram as questões técnicas, às quais ela respondeu muito bem. Mas ninguém atentou para essa última frase. Antes de terminar, eu perguntei: "mas Paula, o que você quer dizer com isso, que não era isso que queria fazer?" Ela me disse o seguinte: "Professor, minha grande vontade, depois que eu terminei o meu Doutorado, era trabalhar sobre o sonho, quais são os processos neurológicos do sonho, como é que o cérebro funciona; mas se eu fosse estudar isso, eu teria no máximo dois trabalhos, porque existe pouca gente estudando isso no mundo; com dois trabalhos, eu não entro em Universidade nenhuma". Então ela torce a sua vocação para ter dez trabalhos. Isso é criminoso. Eu acho que a Universidade, a nossa Universidade, precisa rever muito os nossos passos, o que temos feito até agora. A CAPES, sem dúvida, fez um extraordinário serviço para o Brasil mantendo a qualidade, mas é o momento de ver até aonde se chega: será que esses conselhos são adequados para o mundo em que nós estamos vivendo?

Certamente a Profa. Adelaide, que foi Diretora do interdisciplinar durante muito tempo sabe disso. Ela viveu isso lá. Esse Qualis não pode continuar como está sendo. Um dos grandes problemas que nós temos aqui no Brasil é o ato de olhar para fora e ver como é que eles são e como existe gente fantástica na Europa, nos Estados Unidos etc. Precisamos pensar um pouco sobre como é que eles nos veem. Sabe como eles nos veem? Conto um caso. Em uma conferência na área de Engenharia, alguém perguntou sobre o que aconteceria, qual é a diferença entre países desenvolvidos e em desenvolvimento (agora o nome que eles estão atribuindo é outro: países de economias avançadas e de economias emergentes). Um senhor chamado Sullivan disse o seguinte: "bom, vai ser como sempre foi, nós faremos as grandes descobertas, os grandes avanços, passamos para eles as pequenas manufaturas, os testes, aí eles vão fazendo esses testezinhos". É assim que eles nos veem. Não podemos mais dizer: "bom, e aí?". Nós temos que dizer: "não, não é assim". Nós temos que nos valorizar. Já ouviram falar na luz engarrafada? Procure na BBC, luz engarrafada, de Alfredo Moser, um mecânico de Uberaba. Ele conseguiu fazer iluminação nos seus galpões 
de uma maneira muito original: isso foi espalhado pelo mundo inteiro nos países mais pobres, no Sudeste asiático, entre vários países, e uma dessas pessoas de lá disse que ele deveria ganhar o Prêmio Nobel, mas ele não tem nenhum título de nada, ele é um mecânico.

Temos que nos valorizar. Vocês sabem que o câmbio automático foi inventado no Brasil? Não sabemos disso. Foram os mecânicos da Região dos Lagos, no Rio de Janeiro. A GM soube disso e falou: "bom, nós queremos a sua patente, para vocês não registrarem, nós pagamos \$10.000 cash ou um dólar por carro vendido". O que eles fizeram? É uma falta até de visão. Motor a álcool foi desenvolvido aqui em São José dos Campos. Não aproveitamos o que temos. Nós temos pessoas extremamente criativas, pessoas excepcionais. Temos que nos valorizar. Nós podemos, a USP pode - a USP é a responsável, em grande parte, para levar esse país adiante, porque o que tem de Pós-Graduação aqui é mais da metade do que vem em segundo lugar. É uma grande responsabilidade que essa Universidade tem para fazer revoluções. Uma delas é o conhecimento geral, porque se dizemos o arco do conhecimento, as artes estão inseridas na categoria. Não é igual à Matemática: não colocará na cabeça de ninguém que, a respeito de uma obra sua, ele entenderá como os outros entendem; cada um sente e entende de uma maneira diferente. Mas isso é conhecer. Logo, a Universidade tem que prestigiar essas diversas formas do conhecimento.

\section{8)Prof. Dr. Rubens Russomanno Ricciardi (FFCLRP)}

A Pós-Graduação Profissional é uma solução que confere dignidade à atividade artística e profissional, mantendo um estatuto de Pós stricto sensu e numa confluência fecunda entre mundo do trabalho e linha de pesquisa, entre as quais deve viger uma relação que contemple a multifariedade das iniciativas e a imprescindivel liberdade de inovação e experimento. Inclusive, já que a USP é uma referência, uma Universidade importante nesse contexto, precisamos conversar criticamente com a CAPES e com os setores. Nós pretendemos incluir um novo Mestrado Profissional em Música, que poderá ser o primeiro de artes do Estado de São Paulo, na USP de Ribeirão Preto, para discutirmos a pesquisa voltada à produção artística, portanto, priorizando a práxis e a poíesis. Pela liberdade e multifariedade nos 
caminhos da pesquisa, devemos questionar a estranha insistência da CAPES em forjar identidades. De modo diverso da imposição da CAPES, a autonomia do pesquisador/artista deve vigorar nas relações entre linha de pesquisa e atuação profissional (mundo do trabalho). A exigência da tal coerência entre produção artística e linha de pesquisa leva ainda à deturpação na avaliação da produção acadêmica. $\bigcirc$ foco numa atividade de pesquisa não pode restringir sua atuação profissional. $\bigcirc$ vínculo entre ambas as produções intelectuais, seja a pesquisa teórica, seja a performance prática ou poética, deve contemplar um caráter includente, jamais excludente. As experiências profissionais e de pesquisa devem se enriquecer mutuamente, sem obrigatoriedade de identidade nem coerência, sem prejuizo dos exercícios de inovação. Há caso de colegas "especialistas", os quais priorizam a tal coerência com a linha de pesquisa. Às vezes trabalham com um único tema restrito, sem estabelecer relações externas. Não raramente se tornam produções herméticas, que pouco contribuem com o conhecimento. $\bigcirc$ fato é que não há preceito sério que garanta a excelência da pesquisa por conta de tal coerência. Em ambos, pesquisadores polígrafos ou monotemáticos, independentes de seus mundos de trabalho, há casos tanto de sucesso como de fracasso.

Quando eu entrei na Universidade, em 98, eu tive uma conversa com meu saudoso Prof. Olivier Toni: "Prof. Toni, agora é assim, a gente faz atividade artística atrelada à linha de pesquisa". Ele falou: "Isso é bobagem, não vá nessa, vá na Graduação, trabalhe com a formação do artista, porque a pesquisa deve ser artística, e nós não devemos submeter a linha de atuação profissional da arte a uma linha de pesquisa". Essa liberdade essencial da arte não pode submeter-se a parâmetros que sejam, no sentido poético-prático, redutivos. Temos que ter essa liberdade. As artes são livres, as ciências são livres e a filosofia também deve ser livre. Nesse sentido, a valorização da Pós-Graduação Profissional pode ser um excelente caminho para viabilizarmos o que é a essência do profissional, que é a formação de um ofício. A figura do professor profissional que sabe "pôr a mão" no problema e resolvê-lo é imprescindivel dentro de uma universidade de excelência em ensino e pesquisa.

Ademais, citou-se, de modo oportuno, essa divisão da intuição e da racionalidade, ou talvez, do conhecimento sensivel e de um conhecimento de fato, como se usa o termo, ou seja, em outras palavras, a natureza e a arte. As palavras latinas ratio e verbum foram formas insuficientes 
de abranger a totalidade muito mais instigante do lógos grego, que justamente designa, ao mesmo tempo, inteligência e linguagem. Heráclito define que "todas as coisas vêm a ser segundo esse lógos". João, em seu Evangelho, plagiou o seu conterrâneo efésio de sete séculos antes: "No princípio era o lógos (...). Todas as coisas existiram por ação dele e sem ele existiu nem uma só coisa que existiu". Heráclito entende sempre, de modo separado, o lógos da phýsis e o lógos humano. O lógos da phýsis contempla as leis da natureza e do universo, a Física, a Química, a Biologia, tudo isso que aprendemos é para estudar a natureza, por isso vem o sentido de homologar. $\bigcirc$ que é homologar? É ter o mesmo lógos da natureza. Quando vemos as nossas Congregações e os nossos CTAs, vemos que eles fazem uma espécie de homologação diferente dessa filosófica, pois passa a ser quase um carimbo de cartório, um sentido muito restritivo da ideia de homologar. Na verdade, homologar é estar de acordo com a natureza ouvindo, conhecendo e observando-a, de tal modo que ela seja realmente entendida, homologada em toda a sua harmonia. Esse é o sentido do conhecimento sobre a natureza. Em seu fragmento mais otimista, Heráclito define a condição dinâmica da mente humana, capaz de engrandecer-se, superar-se: "da alma é um lógos que a si mesmo aumenta" - citamos a alma (psyché) enquanto mente, a parte imaterial do ser humano, sua capacidade intelectual, sua sensibilidade, suas condições de pensamento e inteligência. Para Heráclito, "em todos os seres humanos está o bem-pensar e conhecer a si mesmo". Aquele dotado de lógos será ainda capaz de "distinguir cada coisa segundo a natureza e enunciar como se comporta”. E porque vem de légō, do verbo grego que significa expressar na linguagem uma singularidade.

Nós temos, portanto, a homologação na natureza de todo o conjunto de conhecimentos que está presente na natureza e também na Arte, na Filosofia, que é uma expressão de linguagem singular e desveladora. Não se trata da tagarelice do dia a dia, do cotidiano, mas é aquilo que o ser humano diz de diferente. Se reduzimos a racionalidade a um tipo de conhecimento, nós estamos refutando Heráclito, porque o dizer da Arte é também a essência do lógos, a essência da linguagem. Eu não estou usando o termo latino traduzido, ratio, mas o grego, lógos, essencialmente Arte e Filosofia. Por isso, inclusive, a verdade na Arte, que permanece, é inaugurada pelo poeta, que acaba fundando a História. Ela não é refutada; a arte nada tem a ver com refutações. Nas ciências da natureza, verifica-se o sentido de falsidade e veracidade, quando há necessidade de se verificar a verdade por meio de tentativas de 
falsificação. Há, portanto, essa possibilidade. Por isso, a verdade da ciência, ainda mais quando ela é submetida ao contexto tecnológicocultural, é efêmera, às vezes até condenada à obsolescência enquanto a tecnologia faz parte da cultura. Já em relação aos grandes artistas, por exemplo, quando Shakespeare escreveu que "há algo de podre no reino da Dinamarca", como é que nós vamos dizer que isso é refutável? A verdade da arte, nesse sentido, é lógos; é ratio e verbum sempre, sempre-já.

39)Prof. Dr. Luiz Bevilacqua (UFRJ, UFABC, IEA)

Eu quero dizer que está no extremo essa capacidade de transmitir ao seu semelhante aquilo exatamente que se conhece - esse é o meu entendimento quando eu falo de racional. Isso, sob o ponto de vista da Matemática, dessas Ciências chamadas Ciências Exatas, é a capacidade de transferir, tão próximo quanto possivel, bastante próximo, o modo de entendimento das coisas. Há outros tipos de conhecimentos que não são menores, que têm um colorido, um entendimento muito mais rico inclusive.

40)Prof. Dr. Rubens Russomanno Ricciardi (FFCLRP)

Nós podemos falar de homologar, conhecer as leis da natureza e também heterologar, porque a essência do lógos filosófico-artístico é a diferença, daí as diferenças inventivas na linguagem.

4 1)Prof. Dr. Lucas Eduardo da Silva Galon (FFCLRP - Pós-doc)

A temática principal é a rediscussão sobre as grandes áreas do conhecimento, que envolve, obviamente, uma questão de como se organizam as áreas, portanto, uma questão epistemológica. É muito importante realmente rediscutir isso, um pouco para que essa 
transdisciplinaridade, que tanto se fala hoje, aconteça de verdade. Ou seja, é preciso ter uma noção exata de como esses campos funcionam, qual é a lógica interna, o modo de operação de cada campo para que possamos entender isso. Eu acredito que, no caso, quando se fala da questão de como é pejorativo o uso da palavra conservatório, e as grandes instituições são conservatórios, isso, para mim, é um diálogo ruim, em que há uma má compreensão epistemológica entre a área da educação musical e as artes, a Música em especial. Nos artigos da Associação Brasileira, critica-se, com frequência, o ensino conservatorial. Quando se vê, acabou o ensino conservatorial, mas não se colocou nada no lugar.

42)Prof. Dr. Aloysio Fagerlande (UFRJ)

Quando se fala de um modelo acadêmico, da Pós-Graduação em Música, não é a reflexão; a reflexão tem que ter objeto, não existe mais objeto. Quais são os objetos a serem estudados? Essa questão do conservatório é um problema sério. A Europa enfrentou isso com esse sistema duplo, entre as escolas superiores e as universidades. Isso foi morrendo pouco a pouco, porque se a arte não estivesse dentro da Universidade, já tinha acabado. É a nossa realidade: mesmo estando mal dentro da Universidade, ainda está melhor do que fora dela. Por exemplo, quais conservatórios fora da Universidade sobreviveram? Temos um grande exemplo no Estado de São Paulo: Tatuí. Como está o estado de Tatuí agora, perto do que foi há 20 ou 10 anos? No Rio de Janeiro, a Escola de Música Villa-Lobos, com formação técnica, e a Escola de Teatro Martins Pena, que era a principal escola de teatro há décadas, acabaram. Se as artes não estivessem inseridas na Universidade desta maneira, já teriam acabado. Esses problemas todos que nós estamos vivendo é uma questão de sobrevivência.

43)Prof. Dr. Rubens Russomanno Ricciardi (FFCLRP)

Nós tivemos instituições que abrigaram a Arte ao longo dos milênios. Em um primeiro momento, na ldade Média, os artistas estavam 
atrelados à lgreja, à instituição religiosa. Nos primórdios da Universidade, as Artes estavam diretamente relacionadas à lgreja, como sobrevivência. $\mathrm{Na}$ época do Ancien Régime, houve as cortes, a nobreza. $\bigcirc$ artista estava sempre associado a uma forma de bajulação de corte, ainda assim conseguiram ter liberdade para trabalhar. Ocorre que, depois de Napoleão Bonaparte, não temos mais a lgreja, que perdeu a sua força. ○ código civil napoleônico tirou a lgreja entre os mecenas da arte, da filosofia e das ciências. Depois, nós tivemos as cortes, mas as Monarquias terminaram e tornaram-se Repúblicas e Estados que não tinham mais aquele perfil de mecenato (se bem que alguns países na Europa ainda guardam a tradição do mecenato, de nobreza ainda, mas é bem fora da nossa realidade brasileira). As universidades, no século XX, cumprem essa missão. É uma instituição que garante a liberdade inventiva do artista, porque, se nós estivermos restritos ao mercado da indústria da cultura (Kulturindustrie), não haverá liberdade tampouco linguagem experimental. A Universidade é um lugar essencial para viabilizar essa atividade artística, então é uma instituição contemporânea que substituiu, inclusive, com a maior dignidade, o que foi a lgreja e a Nobreza no passado.

\section{4)Prof. Dr. Diego Gonçalves (EACH)}

Em geral, quem se dispõe a falar de ciência e da construção do conhecimento são pessoas da área da Física, da Astronomia. Parte dessa problemática vem justamente de um fetichismo com a Física que as outras áreas criaram ao longo do último século, pelo menos. Parece haver uma necessidade da cópia, isto é, não de como o conhecimento é elaborado, sedimentado, mas de como ele é validado. Essa é a diferença entre as áreas, basicamente. Quem não é da Física dificilmente sabe como a Física funciona ou como é construída. $\bigcirc$ processo não é como aquele divulgado: o cientista vai ao laboratório, vê uma partícula que aparece e a teoria está montada. Na verdade, cada observação gera dezenas, centenas de modelos, que precisam ser, antes de consolidados como o conhecimento verdadeiro (porque a natureza é uma só), validados. Isso vem desde Galileu, na Física moderna, como uma metodologia científica. Nasce como uma ideia de metodologia científica, posteriormente aplicada em outras área. 
Eu não acredito que isso valha para todas as áreas. Nas artes, não existe uma verdade, não existe um conhecimento que seja o verdadeiro, que é o que reproduz a natureza. Não há porque haver a validação. Logo, a metodologia, a produção científica, em termos de artigos (que, na verdade, é uma discussão entre os pares, para que se faça a validação), faz sentido para a Física, consequentemente para a Química, que é parte das ciências naturais, assim como para a Biologia; mas não faz sentido algum para área das Artes. Isso não faz das Artes menos conhecimento, a única diferença é que o conhecimento não precisa ser validado da mesma forma como as outras. Essa questão precisa ser muito bem entendida pelas agências de fomento, pelos sistemas de avaliação, como CNPq e CAPES, e também por nós mesmos, porque quem compõe o comitê de avaliação somos nós.

Quando um comitê de avaliação de Artes discute a qualificação e a qualidade de um programa de Pós-Graduação, levando para dentro da sua esfera critérios de avaliação da Física, da Química e da Biologia, eles estão criando um problema. $\bigcirc$ fato de haver um sistema de validação não faz dessa área mais importante, é algo que é necessário ali. Nas Engenharias, quando se propõe um novo material, é preciso testá-lo, se for aplicá-lo, assim como na Medicina. $\bigcirc$ cuidado tem que ser feito por nós mesmos, tanto nas agências de fomento como na Universidade, na formação dos nossos alunos também.

\section{5)Prof. Dr. Aloysio Fagerlande (UFRJ)}

documento de área da CAPES 2016, em Artes, diz: "a pesquisa em Arte é, por princípio, interdisciplinar pelo fato de incorporar e adequar metodologias e conceitos de disciplinas das mais variadas, seja da grande área das Humanidades, seja das Ciências, para analisar, interpretar e teorizar sobre seu objeto de pesquisa, sempre partindo do princípio de que a Arte é central na pesquisa em Arte". Há a visão binocular, que fala de objeto e de distância. Mas depois, no próprio documento, ele reconhece que "não se trata apenas de utilizar o melhor de cada conhecimento ou de cada área, mas de provocar novas formas de pensar". Abre-se um espaço: "a tensão criativa produzida pelas diferenças é o que mais importa, pois assim não estaremos apenas conhecendo objetos a partir de diferentes disciplinas 
e pontos de vista, mas quando colocando objeto em situação e desta forma redefinindo-o". Ao mesmo tempo em que ela limita, abre uma possibilidade de ruptura. Se essa ruptura não acontece, nós somos culpados, porque o documento permite isso. Borgdorff, em suas palestras, compiladas no livro anteriormente mencionado, comenta principalmente sobre os estudantes das escolas e os conservatórios de Arte, da música e de todas as artes. Quando eles entram no sistema universitário, ficam um pouco apavorados porque, impregnados dos axiomas tradicionais, devem falar com aquela linguagem científica, incorporando o método científico. $O$ próprio aluno começa a se transvestir de uma coisa que, na essência, ele não é. É difícil se libertar disso.

Em suma, esse documento é um pouco ambíguo, mas ele dá margem, ele fala dos métodos científicos adicionais. Enfim, ele possibilita algum tipo de ruptura. Se essa ruptura não acontece, é porque nós não estamos colaborando para isso.

\section{6) Prof. Dr. Rubens Russomanno Ricciardi (FFCLRP)}

Galileu, em 1610, quando olhou para os planetas mediceus (luas de Júpiter) com o seu telescópio recém inventado por ele, introduziu um novo vocabulário nas ciências, que ele chama de systema mundi (sistema do mundo). Essa palavra vem da teoria musical do pai dele, Vincenzo Galilei, que estudou a obra de Aristóxeno, o principal discípulo de Aristóteles e inventor da musicologia. Ou seja, o conceito de sistema, desde o século IV a.C., até o início do século XVII, não ocorreu fora da música. Veja que a Música não é apenas intuitiva, ela tem bases epistemológicas. Hipócrates cita o conceito de sistema, ao falar que o organismo funciona em termos de sistema. $\bigcirc$ modo de pensar científico também pode ser construído enquanto sistema. Contudo, são inequívocas as origens musicais nos primórdios do conceito. Foi a música que ensinou às demais áreas do conhecimento a pensar enquanto sistema, enquanto conjunto harmônico de relações articuladas. 


\section{7)Prof. Dr. Lucas Eduardo da Silva Galon (FFCLRP/Pós-doc)}

Hilton Japiassu, em um de seus livros, comenta sobre o complexo de inferioridade das Artes, das Ciências Humanas, com relação à Física, às Ciências Exatas, que tentam importar os seus aspectos metodológicos de forma precária para essa discussão.

\section{8)Prof. Dr. Luiz Bevilacqua (UFRJ, UFABC, IEA)}

Não adianta atacar o problema na CAPES, tem que atacar na Universidade, não se pode continuar na USP, na UFRJ, na UNICAMP dizendo: "eu vou fazer o meu vestibular para entrar para Medicina ou Engenharia ou Artes". Deve-se entrar para a Universidade. Enquanto esse leque, essa valorização equivalente igual de todas as áreas não for rompida desde o início, não adianta. Serão seus departamentos em cada uma de suas caixinhas, sem que se conversem. Vamos começar na Universidade, quebrando essa barreira, para além do prestígio.

\section{9)Prof. Dr. Wilson Roberto Navega Lodi (FM)}

Na década de 60, o Brasil discutia intensamente qual seria a reforma universitária que queríamos. Darcy Ribeiro e Anísio Teixeira, na Universidade de Brasília, criaram o curso propedêutico, porque eles viam que, no modelo americano, a essencia não estava no Ensino Fundamental ou Ensino Médio, nem tanto também nas Universidades e nas escolas profissionais. A grande diferença estava no College, que era uma espécie de Faculdade de Filosofia. O aluno, que saía do Ensino Médio, deveria entrar para o College, em que faria o propedêutico. Nessa época de 1960, da mesma forma que, em Brasilia, foi proposto o propedêutico, um ou dois anos antes de escolher o que fosse fazer (se fosse fazer ciência ou se fosse fazer uma escola profissional, e qual escola profissional fazer), os conservadores da época criticavam esse modelo, dizendo "eu entro na Universidade, eu quero fazer o que eu quero fazer". Mas você não tem os pré-requisitos para isso, você está jogando 
o pré-requisito para o vestibular. Da mesma forma que em Brasilia, em Ribeirão Preto, por exemplo, tentou-se criar um College Médico. Nos Estados Unidos, há vários tipos de College nas Universidades: uns que trabalham na área próxima da Medicina, outros na área próxima da Engenharia ou na área próxima de Advocacia, além do básico do College, que é formar professores de Química, de Física, de Biologia, de Música para o Ensino Médio. Além disso, o aluno que faz o College, fica mais velho e mais apto para fazer suas escolhas. Quando ele termina o College, pode seguir e entrar na escola de Pós-Graduação. Ela é única no campus. Não é cada departamento que tem a sua Pós-Graduação; há somente uma no campus. Os departamentos podem ser credenciados para fazer Pós-Graduação, mas junto com a Escola de Pós-Graduação. Ou se faz uma escola profissional. Terminada a escola profissional de 4 anos ou a escola de Pós-Graduação, todos têm a mesma idade, entre 25 e 26 anos.

A reforma universitária da USP foi aprovada em 1969, antes do Al-5. Na tarde do dia do Al-5, o Reitor em exercício, Hélio Lourenço de Oliveira, que era um professor de clínica médica da Faculdade de Medicina de Ribeirão Preto e era Vice-Reitor em exercício, conseguiu aprovar a reforma da Universidade. Ele, à noite, descobriu que estava na lista do Al-5, cassado, porque ele, na véspera, tinha se recusado a cassar Jayme Tiomno, Florestan Fernandes e o Arquiteto Artigas. Ele falou: "mas esses três homens que vocês estão me pedindo para cassar são ótimos professores, são a nata da Universidade, não vou fazer isso". Então ele entrou na lista como o último nome do Al-5.

Quem ouviu minha fala deve ter notado que eu faço uma crítica à Pós-Graduação em Ciências. Na Faculdade de Medicina dos Estados Unidos, esse diploma não vale nada: o clínico, o cirurgião etc. foi criado para ter certeza, se ele vai abrir a barriga para ter dúvida, que é o que o cientista tem, eu não vou atrás desse médico PhD e cientista, porque ele é muito confuso, ele tem uma personalidade bipolar. Eu vou ao médico mesmo, porque ele sabe, naquele momento, o que tem que ser feito. Ele vai me abrir e fazer o que precisa; ele não vai ter dúvidas.

A equiparação tem um pouco disso. Na realidade, dentro da Universidade, nossa briga não é com a CAPES, nossa briga é interna, dentro da USP. $\bigcirc$ que for discutido dentro da USP terá repercussão no resto do país e na CAPES também. Seria bom se conseguirmos mudar a ciência e dispensar várias profissões, inclusive os Médicos, Engenheiros

\section{2}

REV. TULHA, RIBEIRÃO PRETO, v. 7, n. I pp. 236-392, jan.-jun. 2021 
e Advogados, de fazer esse diploma extra, que, na realidade, não acrescenta quase nada (ou não acrescenta nada), ao que eles precisam fazer dentro da sua profissão. $\bigcirc$ mundo moderno é um mundo diversificado.

Para este evento, fui ler um livro atual sobre os modelos existentes. Vi uma propaganda da FAPESP sobre um grupo de Campinas que escreveu sobre modelos americano, alemão e francês. Fui ler o texto. Quase joguei fora. Não é que não tenha nada na essência, há muitas informações. Uma frase que eu citei anteriormente, eu peguei dessa leitura que eu fiz. A USP é uma Universidade que vale a pena, tem que fazer essa discussão para criar outros parâmetros. É um paper interessante, eu li, não concordei, mas gostei de ter lido. Ele procura um modelo em 1600 universidades que tem nos Estados Unidos atualmente, e lá tem de tudo, como aqui pode ter de tudo também. Mas aquilo por que nós devemos lutar é para ter uma USP de primeira, que nem as cem primeiras de lá existem e fazem a diferença.

Também, eu quero que as Artes sejam valorizadas, assim como a Medicina seja valorizada, como a Engenharia.

\section{0) Prof. Dr. Jorge Moreira (FMRP)}

Tirar esse monte de títulos e diplomas e fazer um College seria desburocratizar a Universidade. Dessa forma, o estudante de Engenharia, de Medicina ou de Música não entra aos 17 anos, pois ainda não sabe o que quer. Nos Estados Unidos, um estudante de Histologia tem 22 ou 23 anos; aos 30, ele entra na residência. A formação dele é sólida, porque, primeiro, os melhores alunos que nós tivemos eram originários de Colleges Humanísticos, que vinha a conhecer Filosofia, Literatura etc. Tinha diploma em Filosofia, não tinha ideia o que era uma célula ou o que era um núcleo, no primeiro dia. Esses foram os melhores, um grande esforço para adquirir outro conhecimento, mas eles tinham um amadurecimento intelectual, cerebral que lhes permitia avançar. Nós temos um problema muito sério aqui. Com os meninos entrando em Medicina, acaba-se dando aula para 20\% que são superdotados. Quanto aos $20 \%$ que ficam lá no fundo, eu não queria ser atendido por eles. Do meio, ora

\section{3}


saem pessoas muito brilhantes, que amadureçam, ora outros que ficam em áreas que não têm nada a ver com a Medicina.

Eu acho interessante a ideia do College, com a eliminação dos diplomas etc., como se faz nos Estados Unidos. Lá, um Médico já se considera um PhD, a Medicina é uma carreira de Pós-Graduação. Quem faz Pré-Graduação é o College; depois há a especialização e a residência.

\section{1)Profa. Dra. Viviane Nunes (EACH)}

Minha formação é na área de Bioquímica, uma das áreas opressoras sobre as demais. Cada uma das falas de vocês tem uma ressonância enorme em mim, contribuindo para o meu projeto de professora e de orientadora na Pós-Graduação, que eu tenho desenhado nos últimos anos.

Talvez, hoje, eu me encontro exatamente nesse momento bipolar: eu brigo com os meus alunos que são uma "Bioquímica autoritária". "Tem uma dor de cabeça? Remédio!”. Eu acredito no Lehninger, minha bíblia é o Devlin (eu brinco com meus alunos). Nos últimos anos, até por causa da minha formação em ballet clássico, tenho tentado aproximar as duas coisas. Pode-se inaugurar a quarta denominação da Arte: a pesquisa na Arte, que é justamente usar a arte como instrumento integrador no Ensino Superior. Eu acho que talvez as minhas maiores ousadias tenham sido, justamente, ensinar eventos moleculares com os alunos, dançando em eventos moleculares. Já nem é mais a Arte pela Arte, pesquisar a Arte nem para a Arte, nem nada disso, senão usar a arte como um instrumento que possa potencializar o processo de ensino-aprendizagem. Na verdade, essa ideia veio de uma experiência que eu tive no King's College, em Londres, visitando vários cursos de obstetrícia no mundo. Eles têm uma disciplina em cujo currículo oculto está prevista a clinical skills. Nessas clínicas, os estudantes devem cursar disciplinas de Arte, como Música, Teatro, Dança para formação na área de obstetrícia e em outras áreas também em que se precisa intervir, isto é, "mexer" no paciente. 
Esse meu desejo de trazer a Arte para dentro da sala de aula vem um pouco daí também. Não está sistematizado. De fato, termina-se de fazer um teatro e já se escuta: "vamos publicar, vamos escrever um livro". É um reflexo, uma herança da minha área também.

Em relação à Pós-Graduação stricto sensu, lato sensu, Mestrado Profissionalizante, queria fazer, na verdade, uma pergunta, porque eu nem concebo, para minha área, uma Pós-Graduação, um Mestrado Profissionalizante. Eu preciso de gente comigo que queira fazer perguntas, que queira se debruçar sobre essas perguntas, sobre a investigação e, a partir disso, potencialmente podemos ter alguma produção de um conhecimento novo. Mas eu queria perguntar: qual é o problema de se aprovar o Mestrado Profissionalizante, qual é o maior obstáculo, porque, na verdade, eu vejo que quem acha que precisa de um Mestrado Profissionalizante deveria ter o direito de optar por esse caminho. Enfim, eu não sei qual é a temática em torno disso, qual é o problema em torno disso.

\section{2)Prof. Dr. Aloysio Fagerlande (UFRJ)}

Vou separar minha resposta em duas partes. A primeira: eu participei, há algum tempo, na UFRJ, de dois eventos (o Prof. Leopoldo de Meis fazia essas atividades conjuntas sempre - toda semana havia um evento de artes). Eu participei de um em que tocávamos para os alunos dele de todos os níveis. Eu toquei, durante meia hora, no fagote, solo de valsas de Mignone. Depois teve um grupo de capoeira dentro do curso do Instituto de Bioquímica. Semanalmente, havia atividades que faziam parte do curso dele, que sempre estava interessado na perspectiva de integrar a Arte dentro do currículo, mesmo de um modo não formal, não sistematizado. Eu não sei se houve uma intenção de experimento em consequência, eu só participei.

Isso depende do interesse específico de cada grupo, tanto um grupo de docentes quanto um grupo de alunos com determinados perfis, na área de Biologia, de Química, de Física. São fortes os Mestrados Profissionais no ensino de Biologia, de Física, de Bioquímica. Os programas de rede são mantidos pela CAPES, o ProfBio, o ProfQuímica, ProfMat, ProfArt, são os únicos programas profissionais, inclusive, que contam com

\section{5}


bolsas, mas são destinadas a professores de Ensino Médio da rede pública. Trata-se, realmente, de pesquisadores da área. Eu não sei como seria o perfil de uma grande indústria farmacêutica que desenvolveu um produto ou um órgão, enfim.

Quanto ao obstáculo, primeiro seria o preconceito por parte dos pares. Como eu participo de dois programas, há 10 anos no acadêmico e recentemente no profissional, eu fui entrando em todos os órgãos da UFRJ. Houve vaga para o conselho do Ensino para Graduados, que é um conselho consultivo e deliberativo da Pró-Reitoria de Pós-Graduação. Lá, assim que começo a levantar questões, já brincam comigo. Eu falo que represento a minoria da minoria da minoria da minoria... Afinal, se estamos dentro de uma política de ações afirmativas, por que as minorias não podem ser contempladas, bem como os diversos segmentos? Qual a razão desse preconceito?

\section{3)Prof. Dr. Rubens Russomanno Ricciardi (FFCLRP)}

Quando fundamos, no final de 2010, o Departamento de Música da FFCLRP, decidimos, de imediato, pela redação de um projeto de Pós-Graduação profissional. Eu ouvi assim: "por que você vai propor a Pós profissional que é porcaria, que não tem bolsa e que não tem nada? Proponha o acadêmico". Assim se ouve nos bastidores. Mas o nosso grupo, que fundaria, em 2012, o NAP-CIPEM, estava decidido pela modalidade profissional, onde não teríamos uma dissertação culturalista, mas um produto artístico enquanto resultado da pesquisa, um livro didático, uma obra de arte, uma interpretação-execução, um documento audiovisual, um estudo de uma obra em sua linguagem, enfim, trabalhar diretamente com práxis e poíesis em Música, editar partituras, arranjos, composições etc.

Quando Chostakóvitch morreu, a União Soviética já tinha a obra completa dele editada. Já Heitor Villa-Lobos morreu em 1959, mas a sua obra, talvez, não esteja decentemente nem vinte por cento editada. Estamos falando de Villa-Lobos, o maior compositor do Novo Mundo. Falta um trabalho crítico-editorial da obra completa do VillaLobos. Infelizmente, há colegas acadêmicos que têm, não raramente, dificuldades com a partitura e com a linguagem musical propriamente

\section{6}

REV. TULHA, RIBEIRÃO PRETO, v. 7, n. I pp. 236-392, jan.-jun. 2021 
dita, com tratamento direto do material artístico. É o momento de superar essas dificuldades, porque a Pós-Graduação Profissional pode dar uma contribuição valorosa. Vamos enfrentar o desafio e superar esse preconceito que ainda há contra a Pós-Graduação profissional.

\section{4)Profa. Dra. Adelaide Faljoni-Alario (UFABC/CAPES)}

Eu gostaria de reforçar o que já foi falado por todos: o problema está dentro da Universidade, porque a CAPES é a Universidade. Às vezes, há um presidente que pode ir para um lado, para outro, e há um coordenador de área. Mas não sobrevivem muito. Por exemplo, a área de direito não queria um Mestrado Profissional. $\bigcirc$ Diretor de avaliação disse ao coordenador: "ou você aceita um profissional ou sai da coordenação". O Prof. Bevilacqua foi quem propôs a criação da área interdisciplinar na CAPES, que foi criada como multidisciplinar. Ela que levou os profissionais adiante. A área, com cem Mestrados profissionais, dos 400 que a CAPES tem, representa 25\% dos Mestrados profissionais. Nós já estamos na área interdisciplinar com 40 APCN para este ano, de Doutorados Profissionais. Não temos à toa o nome de Sucupira na plataforma de informática computacional de toda a CAPES em função disso. $\bigcirc$ preconceito vem ou de um indivíduo ou de um grupo de indivíduos dentro de uma Universidade. A CAPES é o reflexo do que há dentro da instituição de Ensino Superior. Ela caminha com ele. Atualmente nós estamos com uma Diretora de avaliação que atuou muito na área interdisciplinar na nossa câmara quatro, na área de Biológicas. Eu fui banca do Doutorado da Viviane. Ela tem essa capacidade de olhar um programa de Pós-Graduação como Leiden tanto colocou na literatura, em sua integridade. Afinal, não é somente publicações. Nós somos mais a favor de que o Doutorado seja a formação realmente de um pensador. Não precisa ser na "cultura do elétron", de todas as partículas subatômicas. Ele tem que ser um pensador; essa é a função, por isso se forma um PhD.

A CAPES somos nós: 49 coordenadores que estão discutindo com - Diretor de avaliação. Na realidade, ouvimos muito mais os pró-reitores de Pós-Graduação e os Reitores. Inclusive, nós temos que atender as bases. $\bigcirc$ preconceito de que é menor não existe, não dentro da CAPES. Existe um coordenador que, às vezes, diz: "não quero" ou "imagina, o que 
a Adelaide faz com 100 Mestrados Profissionais?". Fazemos e publicamos, geramos material tecnológico ou de outra natureza. Material, inclusive, que é passado mais rapidamente para a sociedade.

Não se trata de defender ou criticar a CAPES. Aliás, estou na área interdisciplinar na CAPES, que foi rejeitada na USP. Na década de 90, não se conseguiu passar um único curso interdisciplinar na UFRJ. Eu estava promovendo uma "heresia": que os alunos entrassem para a Universidade, não para cursos específicos. Precisa-se levar em conta que a Universidade tem uma resistência muito grande.

\section{5)Prof. Dr. Antonio Sergio Ferraudo (UNESP)}

A favor da prática, eu me lembro de quando o Dr. Chamma, em Botucatu, médico cardiologista, atendeu a toda minha família. Ninguém morreu com trinta anos, morreram com a idade que deveria morrer. Ele era um médico que atendia nas casas, uma prática não reconhecida por ninguém. Eu tenho certeza de que se o Dr. Chamma fosse fazer uma livre-docência, que eu estou tentando com muita dificuldade, ele não poderia, porque ele não tem títulos. Mas quantas vidas esse profissional salvou?

Em relação ao teorema de Pitágoras, que o professor citou muito bem, a parte técnica é uma produção, mas a filosofia é outra. Por isso, fala-se que uma sociedade é pitagórica. Deve-se observar o lado da arte; quanto ao lado filosófico, ninguém faz alguma coisa se não tiver arte envolvida. Qualquer médico ou qualquer um de nós tem um resultado gratificante, pelo qual se emociona. Não precisa ser o teste que conhecêssemos, o teste estatístico. Esses testes podem falhar bastante. A experiência é muito importante.

Eu defendo os cursos profissionais, tanto é que eu criei, junto com meus alunos, há uns dez anos, um programa chamado CIEU. Somente a UNESP de Jaboticabal tem. Ele chama Grupo de Integração Empresa Universidade, porque o nosso jovem sai de lá com a cabeça científica. Nós moramos em um país de terceiro mundo, mas que precisa da resposta do dia seguinte. Não é como a Alemanha e outros países em que um cientista pode bolar um modelo para daqui 30 anos. Nós 
não: o agronegócio está aí, após 40 ou 50 anos, o mundo terá muito mais pessoas, por isso temos que ter soluções rápidas e práticas. $\bigcirc$ Brasil, especialmente, é um grande responsável pela fome ou nutrição do mundo. Serão os nossos jovens que estarão engajados nesse mundo. Se o nosso jovem não tiver emoção, ele não vai a lugar nenhum. Qual é a emoção? Qual é o resultado do teste? É aplauso. Quando o artista sente que a sua música penetrou na alma, no coração de alguém, é um sucesso. Quando nós, estatísticos, temos emoção? Quando vê que aquele método que se aplicou descobriu processos, descobriu que aquilo é linear ou não, que terá uma resposta sim ou não etc. Nisso, há emoção.

Eu estive num grupo em Ribeirão Preto apresentando um resultado estatístico: era uma estatística multidimensional, jogamos para primeira dimensão, não teve nada de novo. Para a segunda, também já sabíamos o resultado. Para a terceira dimensão, de modo muito particular, um médico, que estava presente na equipe, falou: "eu defendo isso faz 10 anos e nenhum teste estatístico falou, agora veio à tona quando você fez um redimensionamento do espaço". Por que ele viu alguma coisa no resultado que eu apresentei para ele? Porque eu não vi nada. Por causa da prática dele. Ele trabalhou dez anos com aquilo, viveu com aquele pensamento. Por isso, curso profissionalizante tem que entrar em todas as hierarquias, não é somente da Universidade. $\bigcirc$ Ensino Médio tem que ter também. Ali já é o ponto de partida; ali, há que sentir as emoções do que é uma resposta profissional, do que é uma resposta da empresa.

Eu fui aprender isso fora da Universidade. Eu trabalho com análise de dados. Sou matemático, e matemático também não tem currículo. Eu dei dez anos de álgebra linear e ninguém me procurou para ser "algo a mais" na vida. Fui somente professor. Não que seja pouco ser professor, mas para minha carreira não, porque, na nossa Universidade, seja qualquer uma delas, em menção às três paulistas, depende-se do currículo. A avaliação é a quantidade que se publica: se eu publicar um trabalho que será lido em 10 anos, não tem valor, é um trabalho somente, isso é coisa simples, mas o mundo inteiro leu.

Então eu emocionei muitas pessoas, mas isso não tem valor. Eu estou com dificuldade na minha livre-docência agora, porque, na UNESP, há quatro itens principais, que são obrigatórios. Depois, há outro que você pode escolher. Desses obrigatórios, eu não tenho um deles. Eu fiz tudo 
aquilo que esse item quer, mas eu não tenho registrado. A Universidade, pois, não me permite. Eu trabalhei para Petrobrás em quase todas as unidades, dando consultoria. Nenhuma tem valor lá dentro. É dificil para todos nós, não é somente a área de Artes não, não é somente a área de Música: analista de dados no Brasil também não tem o seu valor. Quando vamos a uma empresa, pagam-se três, quatro, dez horas para algum serviço que você prestou, mas é serviço prestado. Precisa ter o reconhecimento de que a análise de dados é uma área importante da universidade, que precisa ser transformada em adulta, porque, no momento, ela não é.

Eu sou do Departamento de Ciências Exatas de Jaboticabal, como é que eu vou criar um modelo matemático lá dentro? A estrutura não é para isso, ela é para prática mesmo, é voltada para a prática. Qual é a resposta que a Medicina de Ribeirão Preto dá para a sociedade? É a parte prática. Então a minha fala aqui é uma crítica a essa falta de reconhecimento.

Outro exemplo: São Carlos tem, hoje, esse sucesso no município dele por quê? Porque tem duas Universidades: a Federal de São Carlos e a USP. Ribeirão Preto chegou aonde está por causa do quê? Porque tem uma Universidade, além de outras particulares também, que estão com sucesso. Jaboticabal já ouviu falar isso: "se a UNESP fechar, a cidade para". Nós temos uma resposta para a sociedade, que tem que ser valorizada. Precisamos de uma reforma no pensamento da importância das universidades. Para isso, nós temos que fazer cursos profissionalizantes. Não é a quantidade de publicação, há outras formas de comprovar essa experiência, e isso não está sendo avaliado.

\section{6)Prof. Dr. Fernando Crespo Corvisier (FFCLRP)}

Infelizmente, no Brasil, as coisas não têm uma certa continuidade. Eu estou me lembrando, justamente, de quando foi feito o Instituto de Artes em Campinas. Vem à mente o compositor Almeida Prado, que, depois de Villa-Lobos, foi o compositor que mais compôs obras para piano. Se ele fosse entrar na Universidade, hoje, talvez ele não tivesse composto metade da sua obra, dado às exigências que têm sido impostas aos professores de Música. Graças à produção vastíssima de 
Almeida Prado, consigo realizar o meu trabalho acadêmico, espelhado em suas obras para piano. Ele, por ter formado alunos e compositores, e não somente, mas por todo o tempo que passou na UNICAMP, contribuiu imensamente também com outros artistas que estavam lá. $\bigcirc$ sentido de Universidade, no Instituto de Artes que havia lá no campus, que ainda existe, começou a florescer na década de 70. Era um modelo que tinha que ser pendurado. Infelizmente, não se deu continuidade. Tomaram-se outras direções, para não dizer nefastas, perdendo o foco. Deveria ter tido continuidade.

Nós estamos falando muito, também, na questão da PósGraduação. Eu incluo o problema da Graduação, que, muitas vezes, é negligenciado. Todo modelo, pelo menos desde que eu ingressei na Universidade de São Paulo, sempre foi focado assim na Pós-Craduação. Já ouvi até comentários: "para Graduação, você não dedica muito não, seu tempo tem que ficar muito mais na Pós, que concentra a sua produção, porque a Graduação é só um aspecto secundário". Eu nunca vi com esses olhos, porque, desde que eu fui para Ribeirão Preto, todo o meu esforço foi sempre focado na Graduação. Agora eu vejo com muito bons olhos a continuidade desse Mestrado Profissional, que é, para mim, a continuidade natural dessa Graduação, porque não existe outro sistema que possa dar essa continuidade.

Toda minha formação de Pós-Graduação não foi feita no Brasil, foi feita fora. Eu não tive orientadores que tivessem doutorado, pelo contrário, foram músicos práticos. O Mestrado foi feito no conservatório; todos os meus professores vieram de uma formação estritamente profissional, e eu devo a eles toda essa bagagem que estou passando para os meus alunos de Graduação. Eu vejo assim: nós temos que debater sobre essa questão do Mestrado Profissional como uma forma de tentar consertar essa lacuna, que tem sido imposta para nós. Dispende muita energia essa dubiedade: se eu vou me concentrar para fazer um recital, eu esqueço a pesquisa. Depois eu tenho que pensar na pesquisa, e esqueço a prática. Qual é o norte? Chega um ponto na sua vida que não se consegue mais concentrar tanta energia. Logo, sentese culpa por não estar fazendo um artigo. Sinto-me culpado porque não escrevi aquele artigo, naquele ano, mas eu fiz o recital. Mas ele não tem o mesmo peso desse artigo. Isso sempre paira em nossas cabeças, de como vamos ser avaliados, ainda mais agora que nós temos essa avaliação de cinco anos. Como é que vamos colocar isso de uma forma inteligente? 


\section{7)Prof. Dr. Ricardo Bologna (ECA)}

Também acho que o Mestrado Profissional é uma continuidade dos estudos. Os regentes querem reger, os compositores querem compor e os instrumentistas querem tocar. Se fizer uma pesquisa entre os alunos, 99,9\% falarão que querem tocar melhor piano, querem sair daqui tocando melhor do que quando entrou, querem compor música, reger uma orquestra etc. Para todos os intérpretes, os "práticos" da música, eu acho que isso é uma condição sine qua non. Estamos, na verdade, discutindo o óbvio. "Então, você vai tocar melhor, o aluno vai tocar melhor depois que terminar a Universidade?" Claro, é tão óbvio isso. É óbvio, natural e consequente. Os alunos que terminam a Graduação continuam o Mestrado tocando, continuam o Mestrado regendo, continuam o Mestrado compondo. É claro que é preciso, também, escrever; óbvio que há um processo necessário de passar o seu conhecimento via tradição escrita, via pesquisa, via artigos etc. Mas o centro da pesquisa dessas pessoas é a prática. Eu faço isso há 30 anos. Os meus orientadores de Mestrado que eu fiz na Suiça também eram músicos profissionais, não tinham doutorado. Afinal, quantos doutores eu conheci na Música de que eu não me lembro nem o nome? Nem sei quem são. Eles tocam onde? Compuseram o quê? Regem qual orquestra? Muitos doutores em Música não fazem nada em relação à Música praticamente. Às vezes, eles ficam elucubrando sobre teorias que não fazem nenhum sentido na aplicação prática da Música, absolutamente nenhum sentido.

\section{8)Prof. Dr. Aloysio Fagerlande (UFRJ)}

Na Escola de Música da UFRJ, é a mesma coisa. Já é diferente na Faculdade de Letras. A Faculdade de Letras não forma escritores, forma críticos literários e professores de diferentes modalidades dentro das Letras. Não formam escritores, diferentemente da Música. No caso do Mestrado Profissional, dentro da Música, faz todo sentido, nessa perspectiva. Quando eu fiz o Mestrado, também, meus professores foram sumariamente cassados, porque, na época, houve uma reviravolta na comissão de Artes. A área mais teórica assumiu, e todos os que tinham um notório saber, que orientavam - cito três: Turibio Santos, Heitor Alimonda e Celso Woltzenlogel - nomes de notório saber, que tinham formação

\section{2}

REV. TULHA, RIBEIRÃO PRETO, v. 7, n. I pp. 236-392, jan.-jun. 2021 
na Europa, reconhecimento no mundo do trabalho, de repente, depois das 23 h59 da véspera, não podiam mais orientar, porque não tinham as titulações, embora tivessem um reconhecimento.

59)Prof. Dr. Rubens Russomanno Ricciardi (FFCLRP)

Esse é outro ponto importante que discutimos: não falamos em mercado, nas questões da Pós-Graduação profissional, porque a Universidade, por ter o espírito crítico, forma apesar do mercado, e não para o mercado. Nós pensamos em mundo do trabalho, assim como linha de atuação profissional, com a pesquisa voltada à produção artística.

60) Prof. Dr. Antônio Carlos de Araújo Silva (ECA)

Eu queria ouvir mais de vocês dois sobre a questão da pesquisa prática. Quando o Prof. Bulhões coloca essa questão, existe uma pesquisa que está fundada na prática. Quando passamos horas numa sala de ensaio, trabalhando com ator ou trabalhando na composição visual, plástica, arquitetônica, por tentativa e erro, passam-se meses trabalhando, nós consideramos isso como uma pesquisa feita dentro da prática, uma pesquisa prática. Quando o Prof. Aloysio traz a questão da practice as research, ou seja, a associação entre pesquisa e prática, eu não vejo isso como um movimento de querer se aproximar, querer validar aquilo que fazemos para essas áreas, digamos, mais nobres, tidas como mais nobres, mas por entender que isso que fazemos também é pesquisa.

\section{1)Prof. Dr. Rubens Russomanno Ricciardi (FFCLRP)}

Eu gostaria de que surgisse uma proposta aqui. Eu estive com o Prof. Sylvio Canuto, por conta até de termos o NAP-CIPEM (Núcleo de Pesquisa em Ciências da Performance do DM-FFCLRP), que é atrelado à Pró-Reitoria de Pesquisa. Eu falei com ele: "vamos pensar dentro da

\section{3}

REV. TULHA, RIBEIRÃO PRETO, v. 7, n. I pp. 236-392, jan.-jun. 2021 
sua Pró-Reitoria, a pesquisa elou arte como uma unidade". Ele propôs de fazermos uma discussão. A USP pensa em termos de Graduação, Pós-Graduação, Cultura e Extensão e Pesquisa. As atividades como a nossa, naturalmente, vão para o lado de Cultura e Extensão. Mas o que fazemos não é uma cultura, porque a cultura é a regra, e nós trabalhamos com a exceção. Inclusive, historicamente, sabemos que o conceito de cultura, filosoficamente, não é guarda-chuva para a arte. Aliás, a liberdade da cultura é uma liberdade preguiçosa. A arte é justamente inventiva porque é uma condição rara e privilegiada de viabilizar um distanciamento crítico diante da cultura. Contudo, a extensão, uma atividade fim da universidade, da mais alta importância, está sempre naturalmente atrelada à nossa essência artística. Nas unidades de artes e nos museus é onde se desenvolve a melhor extensão artística, praticada por professores e estudantes, numa relação indissociável com o ensino e a pesquisa - lembrando que eu defino por extensão alienada aquele tipo indesejado de extensão, sem professores nem estudantes, sem ensino nem pesquisa.

Aquilo que produzimos enquanto produto artístico deveria ser reconhecido dentro da Pró-Reitoria de Pesquisa, em sua condição "pesquisa e/ou arte". Quando se encena uma peça ou mesmo se redige um libreto, há todo um imenso estudo prévio, em que lidamos com as mais diversas questões histórico-filosóficas da linguagem. $\bigcirc$ artista, logo, pesquisa. Ao ler as cartas de Van Gogh, ao verificar como ele elabora e produz os quadros, o pintor relata uma série de estudos preliminares, antes da concretização da poética de sua obra. Isso está muito bem relatado nas cartas ao seu irmão Theo Van Gogh. É uma pesquisa diferente das Ciências da Natureza. Contudo, em ambas, há um processo experimental. Tal como o cientista da natureza, o artista autor de obra, também lida com experiências, desenvolve um trabalho experimental. Apenas que se o cientista da natureza busca uma homologação, isto é, compreender as leis da natureza e do universo, o artista, em suas experiências, busca diferenciar os temperos na sua linguagem. A mesma condição ocorre com os artistas da práxis, uma vez que, na interpretação e execução, também se experimentam os melhores caminhos rumo à linguagem do autor. Nesse sentido, é importante que o pesquisador jamais deixe de ser artista. Assim, nós teremos um nível de dignidade e reconhecimento, ao mesmo tempo, a nossa liberdade, para não acontecer como o Prof. Fernando Corvisier mencionou: "vou me preparar para tocar bem no recital ou na gravação, ou antes vou desenvolver uma pesquisa culturalista para publicar um artigo numa revista bem avaliada pela 
CAPES?" O tempo dedicado ao artigo, por certo, prejudica o trabalho artístico. Franz Liszt falava assim: "quando deixo de tocar piano por um dia, eu sinto; quando deixo de tocar piano por dois dias, a minha cozinheira sente; quando deixo de tocar por três dias, o público sente". Nós não podemos perder a mão, pois ela enferruja. Compositor que é bissexto, do mesmo modo, não é compositor. Compositor só é compositor compondo todos os dias. Não existe isso: "ele é bissexto, ele escreve de vez em quando, quando os encargos da CAPES the dão uma folga". Não, ele tem que ter essa dedicação à produção artística por meio de uma pesquisa artística. A nossa produção crítico-intelectual e artística tem que ter liberdade e reconhecimento.

62)Prof. Dr. Aloysio Fagerlande (UFRJ)

Na pesquisa de John Harvey sobre a Música de Mozart, por meio de um instrumento específico, o histórico clavicórdio, os insights sobre as características da Música foram desenvolvidos a partir da sensação desse instrumento. Elas se manifestam na performance, que evidencia a pesquisa, embora também haja uma parte textual para descrever. Ele escrevia sobre essas sensações na Música a partir daquele instrumento específico. Seria um tipo daquele último caso da pesquisa em artes nas artes.

Há, também, questões específicas: tanto a USP quanto a UFRJ exigem um formato de dissertação como trabalho final, seja em profissionais, seja em acadêmicos. Por exemplo, eu fiz este CD com mais três alunos: uma Música para fagote de Francisco Mignone, a partir dos manuscritos originais, com trabalho de edição, recuperação, ensaios, processo de gravação etc. Uma das orientandas que participou da gravação, a Raquel, fez o Mestrado acadêmico e está fazendo o Doutorado acadêmico comigo. Ela está fazendo todo esse trabalho sobre esses manuscritos, que é um volume absurdo, pois são doze quartetos para fagote e com materiais bem precários (apesar de terem uns 60 ou 50 anos de idade, estão em más condições). Já começou a gravar, fizemos recitais, concertos, ensaios no Rio de Janeiro, Belo Horizonte, João Pessoa. Ela está relatando essas experiências. Seria um Doutorado profissional? Não sei. Está dentro do acadêmico porque ela está produzindo uma dissertação com uma metodologia bem definida

\section{5}

REV. TULHA, RIBEIRÃO PRETO, v. 7, n. 1 pp. 236-392, jan.-jun. 2021 
do trabalho de edição crítica, com referenciais. Por outro lado, um dos fagotistas que participou dessa gravação acabou de fazer o Mestrado Profissional. Poderíamos, portanto, ter um outro olhar. Há a questão da visão prismática dentro das artes. Por exemplo: se ele participou dessa gravação, poderíamos descrever o processo da gravação, de como se chegou a esse produto final.

Uma colega nossa da UFRJ, uma das pioneiras no Mestrado Profissional, a Profa. Cláudia Morgado, da Engenharia, fala que não se pode chegar a uma banca com um parafuso de titânio: "está aqui". Não, além de mostrar o produto, é necessário descrever como se chegou àquele parafuso. As possibilidades de pesquisa são variadas. A partir de um relato de experiência, você pode produzir uma dissertação, com seus insights, com suas visões sobre o processo. Ao mesmo tempo, pode-se adotar uma visão mais distante, não necessariamente como aquela visão binocular, de ser o observador a distância, como uma visão musicológica do objeto. Depende da relação com o que se quer fazer. Em suma, há diversas possibilidades: uma não exclui a outra, mas uma não pode dominar sobre a outra.

\section{3) Prof. Dr. Rubens Russomanno Ricciardi (FFCLRP)}

Por isso, o uso da opção "e/ou", ou seja, "pesquisa elou arte", a favor da autonomia e da liberdade. A arte é livre, a pesquisa é livre. Nesse sentido, se o professor ou o acadêmico quiser direcionar sua produção ao trabalho artístico, sendo um professor de arte, ele que tenha a liberdade para que o produto final seja uma obra de arte ou a sua apresentação. Ele concentra seu tempo nisso.

64)Prof. Dr. Lucas Eduardo da Silva Galon (FFCLRP, Pós-doc)

Uma das peculiaridades de um trabalho que tem um produto artístico, como uma apresentação de uma peça ou de uma obra musical, enfim que tenha um produto reconhecidamente já acabado, é que ele pressupõe sempre dois níveis de pesquisa: a pesquisa em si, 
para a produção da peça, e a pesquisa depois da peça terminada sobre o processo de pesquisa. É um problema que enfrentamos mesmo, porque se faz a pesquisa para elaborar a peça (compositor também faz a pesquisa de uma série de formas) e, depois, se se deseja um trabalho, tem que fazer um trabalho sobre o trabalho. Existem dois níveis de pesquisa que, dentro do Mestrado Acadêmico, tornam-se obrigatórios para quem trabalha na performance ou na composição, que pressupõe um produto. Talvez, no caso do Mestrado Profissional, isso poderia ser um pouquinho mais orgânico, mas seria importante não ser tão estratificado.

\section{5)Prof. Dr. Rubens Russomanno Ricciardi (FFCLRP)}

Sobre a crítica genética, atualmente, há uma dificuldade, porque nós editamos partituras no computador, no Finale, no Sibelius. Não existe mais rascunho. Depois de 2.500 anos de História de manuscritos e muitos rascunhos, ninguém mais guarda papel, porque o produto final é uma partitura e suas partes cavadas (o processo inventivo tornase irreconstituivel, sem crítica genética em termos de solfas). Estou me lembrando, agora, da composição musical que eu escrevi para um poema de Fernando Pessoa (Agora que sinto amor). Eu li uns oito artigos sobre o poeta português, fui ver os seus vários poemas e realizações musicais diversas de sua obra. Depois, na minha composição, até me adentrei um pouco nas sonoridades do início do século XX. O produto final foi somente a minha partitura, mas o que está ali por trás, enquanto pesquisa, perdeu-se. Se bem que eu não sei se é tão importante contar sobre isso também. Assim como Claude Debussy detestava análises, a compreensão da obra de arte é algo diverso do trabalho de um legista na autópsia de um cadáver para saber a causa mortis. A crítica genética não deve ser mais importante que a obra de arte em si, mesmo que seja um estudo válido. A universidade precisa reconhecer a importância da poiesis e da práxis. 
Eu trabalhei dois anos em Engenharia e vim para Matemática. Primeiramente, em Ceometria e Matemática pura. Depois, fiz Doutorado em Educação e Holística, então fiz Pós-doutorado em História e Filosofia. Fui mudando o trabalho em relação à Matemática e à Música do ponto de vista histórico e epistemológico.

Em um programa de Graduação, onde eu oriento, ao sugerir uma banca, a comissão falou que, pelo título do trabalho, teria que ter alguém da Educação especial. Fiquei pensando: "O Príncipe", de Maquiavel, pelo tipo de trabalho, seria um "teatro infantil"? Essas questões burocráticas dão muito trabalho, porque é preciso lidar com essa mentalidade burocrática. Fica-se lidando com as situações para ter uma certa liberdade da pesquisa. Fui mudando de área à medida que eu pesquisava e me interessava. Interessei-me pela Matemática, eu vi que tinha elementos da Música. $\bigcirc$ Prof. Rubens comentou sobre - lógos. Quando se pesquisa sobre os Elementos de Euclides, pelo modo como eles compõem razões, ficam relacionados à composição de intervalos musicais contíguos. A terminologia que ele usa está diretamente vinculada à música. A própria teoria pré-eudoxiana de razões é uma generalização da teoria Pitagórica para intervalos musicais. Isso aparece em vários tratados: em Pedro Cirvelo, no século $\mathrm{XVI}$, na Arquitetura, em Alberti etc. Mas a Música tem um certo status nesse contexto pitagórico. Tomei essa trajetória que me ligou a várias áreas. Isso acaba me gerando uma certa dificuldade, dada a árvore do conhecimento. Acaba-se tendo que se subordinar também, tentando driblar o pensando da banca.

Os alunos também têm essa preocupação. Deve-se torcer a vocação para poder ter mais artigos. Também, é comum o aluno, às vezes, ter uma ideia: "então, eu vou dividir em mais artigos porque assim ev engordo mais o Lattes". Fica-se, na verdade, obrigado a se conformar nesse sistema de avaliação.

No contexto da criação da Universidade de São Paulo, a Poli teve uma certa resistência a essa integração. Há várias discussões sobre autonomia etc., mas uma discussão que aconteceu, na época, foi a discussão de os cursos de cálculo de Engenharia serem dados por Engenheiros, e não por Matemáticos. Foi a época de criação da

\section{8}


Universidade de São Paulo: olhando as atas, há várias discussões que acabaram ganhando uma Matemática rigorosa, para dar para o curso de Engenharia.

Eu não sei se esse fenômeno acontece também, por exemplo, nas antigas unidades da Medicina, por exemplo, ou do Direito. Não sei se havia cursos que eram dados por médicos e passaram a ser dados por profissionais de outras áreas, sem a experiência daquela área. Eu mesmo estou dando aula na Atuária nesse semestre, dando aula de cálculo. Mas eu não tenho muita noção da prática profissional de um atuário, vamos dizer assim, um Engenheiro de Seguros. Mas estou dando curso de cálculo integral. Como é que eu relaciono isso? Antes, talvez, fosse mais integrado. Eu fiz Engenharia no ITA, onde havia muitos professores de matemática que eram Engenheiros também. Eu tive certos conceitos de matemática, primeiramente dados por Engenheiros, e não por Matemáticos. A pessoa que tem atuação na área, naturalmente, tem um discurso mais vivo.

Em relação ao Mestrado Profissional, eu acho que é um caminho. Há um problema de mentalidade. Eu estive em bancas de seleção em que, na análise dos projetos, surgem comentários: "ah, isso aqui não dá um acadêmico, dá um profissional". Não se trata de a natureza inerente do trabalho ser própria a um Mestrado Profissional. Há algum valor estranho em que se resolve fazer uma gradação de que o acadêmico é superior, como se fosse uma neonobreza. Nós temos que ficar driblando isso.

Essas discussões de hoje ressoam com a minha prática e com a dificuldade de ter que conviver com essa formatação burocrática da inteligência. A Universidade passa a ser um lugar de recrutamento de trabalho via diploma, que acaba gerando problemas de "cair a ciclovia lá", o avião da Ucrânia que caiu etc. Será que não perceberam que se trata de uma área de conflito? Estudou-se História, mas se decidiu seguir o formulário. Igualmente, com os médicos: segue o protocolo. Há uma falta de integração, de relação em um contexto. 


\section{7)Prof. Dr. Rubens Russomanno Ricciardi (FFCLRP)}

$\bigcirc$ Prof. Oscar João Abdounur é autor do melhor livro, em língua portuguesa, sobre a questão pitagórica da Música. Ele é uma referência essencial sobre esses grandes músicos, tais como Filolau, Arquitas, Aristóxeno, importantes para a posterior propedêutica pitagóricoplatônica, a partir de Cassiodoro, quando se estabeleceu o Quadrivium, as ciências matemáticas divididas em Aritmética, Ceometria, Astronomia e Música. Inclusive, o grande Aristóxeno chegou até nós pelos fragmentos de Euclides, Aristides Quintiliano, Cleonides e Ptolomeu, ao mesmo tempo, músicos e matemáticos.

\section{8)Prof. Dr. Paulo Eduardo de Barros Veiga (FFCLRP, Pós-doc)}

Representando as Letras, principalmente as Clássicas, sou suspeito para dizer que o meu universo é, também, o mundo escrito e o mundo das artes. Há um diálogo absoluto entre as Artes. Na verdade, eu sinto falta desse diálogo, em que se aproximam as Letras com o Teatro, a Música etc. Principalmente no Grego e no Latim, temos um problema que é muito sério: o da sobrevivência. Dificilmente um curso de Medicina será extinto. Ele pode passar por maus momentos, mas dificilmente será extinto. Já os cursos de grego, de sânscrito, dentre outros, são extintos, sem que haja cursos novos. Para além de qualquer discussão conceitual, estamos, ainda, tentando sobreviver. Em geral, cursos de licenciatura e de natureza filosófica não desejam obedecer ao mercado, porque, nesse sentido, tudo o que está relacionado ao mercado tende a nos destruir, assim como ocorre com as artes, em função da indústria da cultura, que as odeia. Ressalto que, nos estudos clássicos, a matriz de pensamento é sempre atual. Por assim dizer, o mundo a.C. é atemporal. Os estudos clássicos transcendem o tempo e são atuais.

Comento, também, sobre a relação que se faz entre discurso poético e discurso científico, como se o discurso poético (artístico) fosse inferior, ou ainda, o discurso mítico também o fosse. Muitas vezes, considera-se o texto mítico como um texto inferior: "ah, não sabe explicar tal coisa, então vai lá para o mito". É até o contrário, no discurso mítico e no artístico, reside o humano, isto é, reside a totalidade do humano. Se tivéssemos um professor muito famoso chamado Aristóteles, ele seria do Departamento de Medicina? Ele seria do Departamento 
de Matemática? Do Departamento de Física? Do Departamento de Direito? Do Departamento de Letras? Ele poderia ter orientandos do Departamento de Música? Então aí reside a matriz de pensamento em uma das áreas, que está para ser extinta ou já foi extinta.

No discurso mítico, no discurso metafórico, em suma, no artístico, reside o conhecimento mais atemporal, mais profundo. Afinal, o poeta e o filósofo são irmãos. A arte tem um vínculo muito grande com as ciências, profundo. Quando se quer teorizar muito sobre a arte, mata-se a arte. É possivel perceber esse aniquilamento em pesquisas que submetem a arte à teoria. Nesses casos, a teoria torna-se mais importante que a arte. Logo, a teoria mata a arte. Ainda mais, ao valer-se de uma teoria fragmentária ("teorias Frankenstein"), usa-se um pouquinho da psicanálise, usa-se um pouquinho do marxismo, sem entendê-lo muito bem, vale-se um pouquinho da linguística, então se faz um pout-pourri teórico e aniquilase a arte, aniquila-se totalmente. Não estou exagerando. É basicamente assim. Por consequência, reflete-se no Ensino Médio: os alunos acham que entender poesia é reduzir o texto poético em um texto dissertativo. Mais uma vez, mata-se arte, porque não é análise literária que se faz.

Eu quero provar o que estou dizendo por meio de um texto poético. Vocês conhecem a história do peixe-lua do Agassiz? Quem conta essa história é um poeta chamado Pound. Ele diz assim:

"Um estudante de Pós-Graduação, singido com honrarias e diplomas, foi a Agassiz, um grande naturalista, para receber os últimos retoques e acabamentos. $\bigcirc$ grande cientista ofereceu-the um pequeno peixe e pediu-lhe para descrevê-lo. O pós-graduando, após um breve momento de observação, declarou: isso é apenas um peixe-lua. Agassiz respondeu: eu sei disso, escreva uma descrição deste peixe. $\bigcirc$ aluno saiu da sala e, após alguns minutos, retornou com uma descrição completa do heliodiplodokus, termo científico encontrado nos livros didáticos, para designar o vulgar peixe-lua. Agassiz pediu novamente ao estudante que descrevesse o peixe. $\bigcirc$ aluno saiu novamente da sala. Dessa vez, demorou-se um pouco mais, mas retornou com o ensaio de quatro páginas produzido por ele mesmo. Agassiz leu o ensaio e pediu-the para olhar para o peixe. Ao final de três semanas, o peixe estava em avançado estado de decomposição, mas o estudante sabia algo sobre ele."

Essa historinha sintetiza as nossas falas. 


\section{9)Profa. Dra. Adelaide Faljoni-Alario (UFABC/CAPES)}

Esta é a plateia ideal para fazermos um agradecimento para a Profa. Antônia Pereira, que modificou a estrutura da Coordenação de Artes. Ela é da Federal da Bahia, artista da dança e do teatro. Ela falou: "se existe o Qualis Al da Science, da Nature, então eu farei um Qualis da Artes". Ela trabalhou quatro anos junto com os coordenadores de área e gerou o Qualis artístico. $O$ documento de área era um documento fantástico. Ela sentiu o que os coordenadores queriam para a sua PósGraduação, e os profissionais são muito bem-vindos. Ademais, na área interdisciplinar, já existe a linha de atuação profissional nos Mestrados e Doutorados Profissionais, porque é isso que se propõe a fazer, está no documento de área.

\section{0)Prof. Dr. Ary Plonski (IEA)}

Eu estava em uma banca de Mestrado Profissional em Empreendedorismo na FEA, de um orientando meu, que é um executivo de uma multinacional e que tem uma proposta extremamente interessante e inovadora de se fazer uma articulação entre grandes empresas, startup, programas etc. Enfim, ele está desenvolvendo uma proposta extremamente inovadora. Ele, evidentemente, fez a proposta, escreveu quase o que seria o exame de qualificação, quase um artigo tecnológico - se é que posso chamar assim. Mas em março, nós tivemos, na USP, o novo regimento da Pós-Graduação publicado. Esse regimento iguala as dissertações de Mestrado Acadêmico e Profissional e também, imagino, que as teses de Doutorado Acadêmico e Profissional. Ou seja, o produto necessário é exatamente o mesmo.

Eu sempre fiz minha vida aqui, na Av. Prof. Luciano Gualberto. Sou professor do 908, que é a FEA, do 1380, que é a produção, e também eu fui dirigente do IPT por cinco anos. Na época em que a USP não queria mais Mestrados Profissionais, no IPT, abriram-se quatro Mestrados. Convidei para aula magna dos quatro Mestrados, o Prof. Jorge Guimarães, que, na época, era o presidente da CAPES. As aulas dos Mestrados são à noite, porque as pessoas trabalham de dia, evidentemente. $\bigcirc$ Jorge falou: "eu venho, mas com uma condição, eu quero vir durante 
o dia e ver o pessoal trabalhando nos seus projetos de pesquisa nos laboratórios do IPT". Evidentemente o recebemos, passou o dia com a gente, almoçou com a gente. À noite, ele fez um depoimento muito bonito. Essencialmente, a mensagem que ele deu foi que o essencial era o resultado da pesquisa, menos do que a formatação no processo tradicional e a conclusão. Na verdade, evidentemente, não devemos jogar as questões na responsabilidade da CAPES. As nossas instituições, às vezes, são mais "ortodoxas" do que o próprio regulamento.

Eu tenho uma pergunta: até que ponto essa reação mais ortodoxa das instituições acadêmicas, inclusive esta na qual, com muita alegria, militamos há tanto tempo, tem relação com a importância crescente que se dá às classificações acadêmicas, especialmente internacionais? Ou seja, refiro-me aos rankings, em que a pontuação é com base em dados objetivos (publicações etc.), bastante metrificado nesse sentido. Em outras palavras, a pergunta é: por que, afinal de contas, há essa reação ortodoxa? Essa reação é ortodoxa mais do que a prescrição, isso é claro. Agora, por quê? Minha hipótese é que os rankings têm a ver com isso.

Quero fazer, além disso, um depoimento: eu fiz a Poli e o IME, eu sou da época exatamente da transição. Por isso, eu fiz a Poli, com Cálculo, Física etc., com professores de Engenharia. No final do curso, quando eu já tinha feito as disciplinas básicas, elas já passaram a ser dadas no modelo que todos nós conhecemos. Eu sei que as turmas subsequentes se queixavam de que o primeiro e o segundo ano na Poli era, na verdade, o quarto e quinto anos científicos. Então houve essa queixa e houve uma exceção. $\bigcirc$ Prof. Osvaldo Fadiga Pontes Torres diz que conseguiu fazer uma exceção com as disciplinas de probabilidade e estatística, porque ele temia que, se fosse dado, o pessoal sairia aprendendo a teoria axiomática da probabilidade, mas saberia fazer o uso pragmático que a pessoa de Engenharia teria que ter.

No caso, essa disciplina, probabilidade e estatística, era para toda a Poli. Ela deveria ser dada, teoricamente, pela Matemática (pelo IME), que tem toda a condição, evidentemente. Mas, por uma questão pessoal do antigo Diretor da Poli, ficou desse jeito heterodoxa.

Mas a pergunta é: os rankings são importantes? 


\section{1)Prof. Dr. Rubens Russomanno Ricciardi (FFCLRP)}

Quando iniciamos o debate, no primeiro encontro, nós tivemos - depoimento da Profa. Icléia Thiesen, que é da área de Ciências da Informação da UNIRIO, que veio como convidada. Ela mostrou a necessidade urgente de atualização, em termos críticos, das conclusões do Manifesto de Leiden, em justa crítica a essa cientometria, quer dizer, a razão calculadora que elimina até o incomensurável. Houve uma unanimidade no primeiro debate. Vários colegas chegaram a mencionar o problema até dos rankings, que são dirigidos por jornais particulares com interesses comerciais. Essa concepção de Universidade a partir dos rankings é extremamente perigosa. Já ouvi o Prof. Vahan Agopyan dizer: "estou falando do ranking, mas eu sei que existe uma crítica forte dentro da Universidade contra o ranking". A Reitoria da USP já está pensando criticamente os caminhos da Universidade, que não deve se atrelar a métricas arbitrárias.

Sugiro que todos leiam o Manifesto de Leiden. Nós não devemos construir o nosso conhecimento em função de uma cientometria redutiva, porque a vida universitária é muito maior do que isso. A crítica a esse produtivismo de paper se deu por unanimidade. Foi uma crítica bastante contundente. $\bigcirc$ passo seguinte é: como valorizar, independente desses rankings, a atividade docente? A oportunidade que a Reitoria está nos dando, nesse novo processo de avaliação, é que o departamento escreva, antes de mais nada, o que é importante. Isso é essencial. A definição da missão institucional deve vir das bases. Assim, a carreira acadêmica será construída de baixo para cima, vislumbrando justamente as singularidades de cada setor. Afinal, a Universidade tem que ser crítica e dinâmica, privilegiando as diferenças em theoria, poíesis e praxis nas mais diversas áreas do saber.

Além dessa questão, foi muito comentado que a produção intelectual e artística nem sempre é voltada para temas internacionais. Às vezes, o pesquisador está resolvendo um problema regional; e o problema regional nem sempre tem uma repercussão internacional. E não podemos nos esquecer da importância social que esses projetos regionais muitas vezes têm. Nós temos que contextualizar essa questão do que é o internacional e o que é o regional. Em termos de arte, Brecht falava assim, sobre as artes: "as grandes obras internacionais são as obras nacionais, e as grandes obras nacionais acolhem em si as 
inovações internacionais". Temos que pensar sobre a internacionalização de um modo mais efetivo. Por exemplo, se estudo Oswald de Andrade e mando um paper para uma revista yankee-estadunidense, que seja importante na área de Artes, eles vão responder assim: "excuse me, Sir, but who is Oswald de Andrade?" As ciências da natureza procuram homologar, ter o mesmo lógos, isto é, compreender as leis do universo e do cosmo, bem como a evolução da vida. Todos pesquisadores querem publicar na Nature e na Science, porque as questões da Física, da Química e da Biologia são naturalmente universais. Quando trabalhamos com arte, temos valores regionais muito importantes. Eu não consigo publicar, assim, numa revista internacional, um artigo fruto de uma pesquisa sobre os regimentos de pardos libertos no termo da Vila de São José na Comarca do Rio das Mortes. Não fazem sentido os paradigmas das publicações internacionais e indexadas das ciências da natureza impostas nem às artes nem aos estudos culturais, quando necessariamente regionais.

Em termos de produção intelectual, as artes (seja na theoria seja na poíesis) têm quase três mil anos de História com textos divulgados em manuscritos e, desde Gutenberg, em livros. A dimensão do paper indexado, sempre restringido pelo consensum sapientium da junta diretiva de cada revista em suas idiossincrasias, por exemplo, estão quase sempre aquém das necessárias dimensões de uma crítica de fato histórico-filosófica. Em relação ao formato que acaba tendo o fruto de uma pesquisa em artes, tal qual uma gravação audiovisual, desse modo, sairia fora desse padrão CAPES das revistas.

\section{2)Prof. Dr. Ary Plonski (IEA)}

Evidentemente concordo com os cuidados para se fazer o Ranking. Temos feito diversas críticas. No caso de Leiden, conhecemos bem. Sobre um conceito bastante interessante, que é multi-ranking, cada Universidade, a partir de uma base de dados, estabelece as ponderações de acordo com o seu jeito. A USP faz parte de um grupo internacional que está procurando olhar como é que conseguimos valorizar, nos rankings que existem, a extensão e o empreendedorismo, dentre outros tópicos que não entram na medida. A minha pergunta 
era de natureza mais cultural: até que ponto esse fato da realidade influencia esse comportamento mais ortodoxo?

\section{Encerramento}

\section{3)Prof. Dr. Rubens Russomanno Ricciardi (FFLCRP)}

Com certeza, estamos confluentes na crítica contrária à métrica única e padronizada de avaliação acadêmica, que acaba sendo excludente e prejudicial. Devemos lutar pela liberdade nas ciências, nas artes e na filosofia, reconhecendo as missões institucionais diferenciadas. Dado o avançado da hora, agradeço a presença de todos. Esperamos tê-los aqui em uma próxima rodada, em que possamos viabilizar, quem sabe, um grupo de estudo, formalizando as questões levantadas nestes encontros. Muito obrigado. 


\title{
III Seminário (Re)discussão sobre as grandes áreas do conhecimento
}

\author{
IEA-USP \\ 04 de outubro de 2018 \\ Link de acesso ao evento: \\ https://www.youtube.com/watch?v=dCb7 4U5cTxsEt $=40$ s
}

Local: Sala Alfredo Bosi - Instituto de Estudos Avançados da Universidade de São Paulo

Coordenação: Rubens Russomanno Ricciardi (DM-FFCLRP)

Participação dos Professores da USP

Eduardo Henrique Soares Monteiro (ECA)

Eliseu Martins (FEA, FEARP)

Hugo Tourinho Filho (EEFERP)

Jorge Mattos Brito de Almeida (FFLCH)

Lia Queiroz do Amaral (IF)

Marcelo Papoti (EEFERP)

Myrian Nunomura (EEFERP)

Tito José Bonagamba (IFSC)

Et alii. 


\section{Abertura}

74)Prof. Dr. Rubens Russomanno Ricciardi (FFCLRP)

Já são três encontros em que discutimos as questões das áreas do conhecimento, inclusive, com a participação de todos os principais setores da Universidade. Criticou-se o critério único na avaliação das mais diversas carreiras acadêmicas. Esse quesito prejudica o desenvolvimento dos cursos e dos departamentos. Ademais, falta valorizar os saberes profissionais, os ditos conhecimentos prático-poéticos, que estão sendo negligenciadas. Nós tivemos testemunhas de vários colegas, de grande mérito, que clamam pela valorização da Pós-Graduação profissional e da pesquisa voltada à poíesis e à práxis. Essas questões não envolvem somente o âmbito artístico, mas também têm a ver com as engenharias, a medicina, a odontologia, os esportes etc.

Foi também unânime, entre os colegas que aqui estiveram, a importância do Manifesto de Leiden, que é um manifesto internacional que critica alguns critérios redutivos de cientometria e que nos encaminha para discutir melhor a questão dos rankings na Universidade. Muitas vezes, as universidades são avaliadas por rankings internacionais, administrados por jornalistas e por jornais distantes do mundo do ensino e da pesquisa. Portanto, não dão conta da diversidade nas atividades organizadas e realizadas na Universidade. Por isso, precisamos questionar a condição de a Universidade estar refém desses rankings, com seus critérios não raramente arbitrários, até por conta da pressão da mídia, quase sempre envolta em implicações neoliberais de negócios.

Com vários artistas participantes, nós tivemos encontros fecundos, que culminarão em um seminário estratégico: "A Pesquisa em Artes: uma discussão conceitual”, a ser programada junto à Pró-Reitoria de Pesquisa da USP. Afinal, a pesquisa em artes está sendo tratada de modo redutivo e confundida com os estudos culturais.

Conversando, ainda, com o Prof. Hugo Tourinho, nosso colega da Escola de Educação Física e Esporte de Ribeirão Preto, falamos tanto sobre a necessária valorização da práxis nas artes representativas e nos esportes como também da questão das patentes. Há um tipo de pesquisa científica que gera patente. A obra de arte, em si, deveria receber um reconhecimento similar à patente. A USP produz, todos os 
anos, milhares de papers e apenas algumas dezenas de patentes. Será que esta proporção está sendo benéfica? Vamos ouvir, agora, as falas dos professores convidados. Obrigado.

\section{Falas iniciais}

75)Prof. Dr. Jorge de Almeida (FFLCH)

Quando eu estava na Graduação, o professor Rubens foi o meu maestro. Eu frequentava as aulas também da ECA. Acho que foi o primeiro grupo que o professor regeu. Depois, eu fiz parte do madrigal da ECA, com o Prof. Marco Antonio Ramos. Tenho acompanhado muito a carreira do Rubens como maestro, compositor, também na Universidade. Eu assisti aos dois últimos encontros, gravados em vídeo e fiquei impressionado com a riqueza e a diversidade das contribuições para esse debate que é tão importante. Eu me lembro de o nosso grande fagotista, Fagerlande, falar sobre as dificuldades no Rio e de como a avaliação dos departamentos não contemplava a produção de CDs que ganharam prêmios internacionais de música. Eu vi, também, outros colegas músicos, nossos colegas diretores de teatro renomados, que fazem parte da História do Teatro brasileiro, falarem: "olha, a montagem de uma peça com meus alunos, que dura um ano, vale menos que um paper escrito por um dos outros alunos sobre essa mesma peça numa revista indexada". Tivemos contribuições interessantes do colega da Astronomia, mostrando como o caráter não prático, não tecnológico da formação do saber, que é tão importante para toda a ideia real de Universidade, tem encontrado problemas também. $\bigcirc$ colega da cirurgia, com todos os problemas, não é avaliado por sua habilidade, por sua história como cirurgião, ficando prejudicado na carreira por quem publica, mas não opera, inclusive, indicado para a cadeira de cirurgia.

Representando a Faculdade de Filosofia, Letras e Ciências Humanas, que é muito ampla, pois tem diversos cursos, tenho o objetivo de falar um pouco sobre, nesse âmbito, a ideia de tradução. Sou membro do Conselho do CITRAT, que é o Centro Interdepartamental de Estudos de Tradução e Terminologia. Nós temos o mesmo problema, muito similar ao pessoal do teatro e da música, em relação à nossa produção de tradução criativa, tradução técnica terminológica. 
Antes de entrar nisso, vou fazer algumas considerações bem rápidas, porque, ontem, foi um dia importantíssimo para a nossa Faculdade: foi lembrada a famosa Batalha da Maria Antonia, em 68. $\bigcirc$ Prof. Eliseu estava nessa batalha, quando a Faculdade de Filosofia ainda era Faculdade de Ciências. Lembrando-me desse momento, cada vez mais atual infelizmente, menciono um ensaio do Prof. Antonio Candido (recém-falecido, um dos grandes mestres da formação de todos nós, na Faculdade de Filosofia), "Um Mundo Coberto de Moços", em que ele faz uma análise da evolução da Faculdade, da evolução da Universidade de São Paulo, que começou com conhecimento contemplativo, sem se misturar com as questões reais do país. Depois, a vinda de professores estrangeiros, curiosamente, que queriam estudar o nosso país, incentivou os alunos a participarem de maneira muito mais ativa, com intervenções políticas e culturais de toda ordem, num projeto de nação, que foi interrompido com a Ditadura. Depois, foi retomado com enorme custo. Vamos ver o que acontecerá. Nós estamos aqui discutindo aspectos da futura avaliação, que deve passar, antes, pela defesa da Universidade, nesse sentido.

$\bigcirc$ Prof. Antonio Candido escreveu, também, um texto fundamental para a nossa discussão, que recomendo a todos: "O direito à literatura". Não se trata apenas de literatura, mas também de música, de teatro. Nesse ensaio, nessa palestra brilhante, ele argumenta que o acesso a obras culturais de valor é um direito universal e deve ser, portanto, também acolhido pelo Estado na sua oferta, no seu desenvolvimento, na formação de profissionais, de público. Ter o contato com boa arte, boa literatura, bom teatro é fundamental, não apenas para a sociedade como um todo ou para o projeto de nação, mas para cada indivíduo em particular. Ele estava retomando uma ideia de Universidade que nasceu na Alemanha, com Alexander von Humboldt, de uma Universidade com fundamento da Bildung, da formação, como meio de unir, nesse caráter universal, que ela propõe até no nome, o homem cada vez mais fragmentado pela divisão social do trabalho. Se no século XIX era um problema, imagina no século XXI.

Recomendo a todos também a leitura de um livro importante do Prof. Christian Laval da Universidade de Nanterre. Ele mostra como a lógica capitalista, ideológica e econômica atual invadiu a Universidade. Nós temos, agora, indivíduos pesquisadores autônomos, ligados a redes internacionais, avaliados segundo critérios de produtividade, pagando caro para publicar em revistas indexadas dominadas por oligopólios

\section{0}

REV. TULHA, RIBEIRÃO PRETO, v. 7, n. I pp. 236-392, jan.-jun. 2021 
editoriais, fazendo propaganda de si mesmos e buscando sua produtividade na concorrência, e não na colaboração. Dessa forma, buscam uma maximização de lucro de capital cultural, que é um termo horroroso, pensando na avaliação de si próprio e dos outros a partir de critérios quantitativos, esquecendo essa ideia do comum, essa ideia fundamental da Bildung, da formação individual ligada a um projeto comum.

O problema é que nós introjetamos essa lógica independentemente da nossa opção política. Ela foi introjetada nas normas, nas nossas regras. Cada vez nós somos mais cobrados por esse tipo de lógica produtivista. Isso afeta até mesmo as humanidades, infelizmente, que deveriam ser o antídoto para isso. Nós estamos vivendo - isso já foi discutido nos outros encontros - um momento de crise das humanidades no mundo inteiro: várias áreas ligadas às humanidades estão sendo fechadas em universidades importantes ou diminuidas. Foi citada, inclusive, uma proposta esdrúxula legislativa de acabar com todos os cursos de ciências humanas e humanidades em universidades públicas em nosso país. Eu até achei que fosse fake news. Conferi no site do Senado e estava lá a proposta legislativa. É realmente impressionante. Assistindo aos debates dos candidatos a governador, nesta semana, quando perguntados sobre a função da Universidade Pública, todos eles, com exceção de dois, não caíram nessa visão da Universidade como polo tecnológico ligado à formação para o mercado. A palavra polo tecnológico é onipresente, e foi falado de disfunção, de dispêndio, de falta de recurso. É um discurso completamente alheio a necessidades reais das universidades e ao papel que as universidades paulistas, as três universidades paulistas, no caso dos governadores, têm na configuração da pesquisa, da ciência, da educação, da cultura, em todos os âmbitos no nosso Estado e no nosso país. A contribuição do nosso país para o mundo, inclusive, passa em grande parte por essas universidades.

Quanto ao nosso tema sobre a valorização de informações não teóricas, mas prático-poéticas, mesmo na teoria, há duas concepções diferentes. Uma é a teoria tradicional, que se baseia na quantificação, na busca de resultados universais objetivos e necessários, na formulação do método científico. A outra teoria, que foi chamada na Alemanha de kritische Theorie, de Teoria crítica, dialoga com essa visão tradicional de teoria, mas busca criticar os seus próprios pressupostos, entender a prática da teoria da ciência em contextos culturais e sociais, fazer mais 
perguntas, buscar mais perguntas do que necessariamente encontrar respostas, afinal, buscar perguntas é essencial também, do ponto de vista teórico. Nesse sentido, não é possível separar tanto arte, ciência, teoria e prática. O caráter crítico da teoria envolve o reconhecimento como prática social, como prática política. Não por acaso, isso surgiu na Alemanha, logo antes de uma das catástrofes mundiais, que culminou em reflexões fundamentais sobre o papel da Física, da Engenharia e da Tecnologia, no grande massacre da primeira grande guerra e no cataclismo nuclear da segunda. Lembro a peça de Dürrenmatt, Os Físicos, ou de Brecht, A Vida de Galileu, que mostram, justamente, como os físicos contemporâneos e Galileu já tinham de lidar com questões éticas, políticas, históricas muito importantes.

Outra questão é a divisão entre estudos culturais e poíesis. Nós temos disciplinas de estudos culturais, em que há uma atenção muito grande ao aspecto formal das obras, a crítica do valor estético, da história de cada gênero literário e artístico. Por outro lado, quem trabalha só na criação, inevitavelmente, tem que lidar com aspectos culturais da recepção, da produção e tudo mais.

Vou ao caso específico que nos interessa do ponto de vista prático e também teórico, que é a questão da tradução. Sempre houve uma intensa atividade de professores da Universidade, no âmbito da tradução, não apenas da tradução literária, mas também da tradução científica. Por exemplo, refiro-me a textos fundamentais de Anatomia. Havia dois colegas que tinham traduzido, do latim, o Vesalius, o grande livro histórico de Anatomia. A coleção "Os Pensadores" foi, praticamente, toda produzida e traduzida em plena ditadura. Esses livros tiveram uma enorme importância no cenário cultural, traduzidos por professores da nossa Faculdade e da nossa Universidade.

Também temos a questão da tradução literária. Vários dos nossos colegas são grandes tradutores literários. É curioso notar que, em 2012, surgiu um programa de Pós-Graduação especificamente ligado à tradução, a Tradusp, que era uma iniciativa interdepartamental, juntando gente de várias áreas para pensar a questão da tradução, a partir de vários pontos de vista, da recepção, da tradução terminológicocientífica, da tradução poético-crítica, da tradução literária, e assim por diante. Surgiu em 2012 e já está em crise. Teve problemas graves de avaliação, apesar de o CITRAT funcionar muito bem. Nós temos um problema com as avaliações, mesmo nas nossas áreas de Letras. Por

\section{2}

REV. TULHA, RIBEIRÃO PRETO, v. 7, n. I pp. 236-392, jan.-jun. 2021 
exemplo, traduzir As mil e uma noites, em cinco volumes recheados de notas, como fez o nosso colega, Mamede Jarouche, é um acontecimento mundial, pois é uma das poucas traduções completas. Porém, para avaliação, vale muito pouco.

Recentemente, na avaliação dos livros pelo Qualis, sobre a produção do departamento das áreas de grego e latim - que traduziu A Odisseia e, também, textos fundamentais de Platão, a produção lírica latina, dentre coisas extraordinárias - todos foram considerados LNC, ou seja, livros não classificáveis do ponto de vista acadêmico. Imagina todo o trabalho, todo o conhecimento, toda a dedicação que um professor precisa ter para traduzir obras dessa importância. Não me refiro apenas a traduções de textos clássicos, incluo textos contemporâneos também. Nós estamos com um problema, agora, também com nossos colegas do japonês, do russo, do coreano, do hebraico, do árabe que tinham programas individuais, mas que se juntaram. Soube agora, também, com a participação do nosso colega, que todos eles estão com dificuldade, porque a produção desses programas foi considerada muito pequena, havia problema de poucos professores. No entanto, a especificidade de cada uma das línguas e das traduções é o que geraria, com o correr do tempo, uma tradição. Ninguém nasce tradutor, ninguém começa a traduzir assim, há toda uma escola de tradução. Ou seja, aprende-se a traduzir vendo ou discutindo suas traduções com outros colegas que dominam línguas estrangeiras, como o japonês, o russo, o coreano, o grego, o latim. Ainda é fundamental dominar a língua de chegada, além da possibilidade da versão, que é a tradução das obras fundamentais escritas em português em outras línguas. Isso tudo foi muito mal avaliado.

Mas, afinal, o que é a tradução? Ela tem um aspecto teórico, uma produção imensa, muito relevante, sobre teoria da tradução. $\bigcirc$ aspecto histórico, a História da tradução, a História da recepção, a História do desenvolvimento da cultura do livro e tudo mais é interessantíssimo. No aspecto prático, nós formamos também intérpretes. Isso corre o risco de acabar. Nós tínhamos, há pouco tempo, cinco ou seis grandes intérpretes de alemão que sempre eram chamados para traduzir convidados estrangeiros. Agora, muitas vezes, estão pedindo para que a pessoa fale inglês, porque não tem mais alguém para fazer a tradução simultânea. É uma situação complicadíssima.

Esse aspecto técnico é importante também na formação de tradutores para tradução juramentada, diplomática, porque não se sai

\section{3}

REV. TULHA, RIBEIRÃO PRETO, v. 7, n. I pp. 236-392, jan.-jun. 2021 
falando inglês porque é a língua comum. Não, cada língua traz a sua cultura, seus valores, a representação de uma história toda que deve ser respeitada, incentivada e valorizada, como a nossa.

Assim, o Manifesto de Leiden chama-nos atenção para essas questões também. $\bigcirc$ incentivo à publicação, em inglês, rompe com o desenvolvimento de traduções locais e questões locais, que seriam muito mais importantes. De repente, na Alemanha, cursos de literatura alemã estão sendo dados em inglês para os alunos estrangeiros, porque é bom para a Universidade ter alunos estrangeiros. Nós temos artigos nossos sobre literatura brasileira valendo muito mais porque foram publicados em inglês ou em alemão, em revista estrangeira, que tem problemas de aceitar as nossas traduções.

Além de tudo, a tradução tem o trato poético. Para traduzir um texto literário, é necessário ser artista também, dominar as formas de expressão, muito complexas. Não é nada simples. Logo, a tradução embaralha essa questão teórico-prático-poético de um jeito muito interessante. Então, minha fala vem no sentido de nós aproveitarmos esse espírito da tradução, que é tão relevante, para que ele paire sobre nossas tentativas de traduzir as várias áreas: Música, Contabilidade, Educação Física, Economia, Astronomia, Medicina... porque quem faz isso dá uma enorme contribuição para a cultura como um todo. Eu dou uma aula sobre o ensaio como forma, em que eu mostro a importância de grandes ensaístas em várias áreas. Por exemplo, Stephen Could, na área da Biologia, Oliver Sacks, na Neurologia, Carl Sagan, na Astronomia, Richard Fairman, na Matemática, são grandes cientistas em suas próprias áreas que, ao dominarem a prática do ensaio, ligado à expressividade, conseguiram atingir um grande público e contribuir para esse ideal de formação geral, que a Universidade deve manter e deve continuar se baseando na docência, pesquisa e extensão e em suas mais variadas formas.

76)Prof. Dr. Rubens Russomanno Ricciardi (FFLCRP)

Alguns traduzem Bildung por formação ou formação acadêmica, conhecimento geral. Mas a acepção de Bildung em alemão implica necessariamente numa dimensão semântica mais ampla e instigante, 
algo como a constituição crítico-intelectual de uma pessoa. Não basta saber, obter informação. Há que se pensar criticamente, incluindo-se novas combinações inventivas a partir do conhecimento adquirido. Como meu mestre saudoso, Olivier Toni, dizia: "nunca acredite naqueles que leem só aquele livro preto", pois aí se configura, justamente, um caso de ausência de Bildung. Nela, temos sempre que querer saber mais sobre muitas coisas, fundindo os horizontes crítico-intelectuais.

Assim como Heidegger falava do esquecimento do ser (uma das teses centrais em sua obra), nós vivenciamos, agora, o esquecimento da poíesis. Os estudos culturais estão eliminando a poíesis. Nós fizemos um levantamento em diversos cursos de Letras: não se usa mais a palavra arte-poética-literária. Na FFLCH, por certo sim, como reitera o Prof. Jorge de Almeida, mas não em termos nacionais. Fala-se de obras literárias que não são integralmente lidas, e o próprio conceito de poética está sendo confundido, de modo ignorante, como mero manual obsoleto.

Há uma epistemologia proposta pelo nosso grupo de trabalho da USP de Ribeirão Preto (NAP-CIPEM), a qual chamamos de poíesis crítica, em que criticamos o relativismo cultural ou culturalismo. Inclusive, chamamos de culturalismo nilista ou mau relativismo, em que se consideram as artes, as ciências e a filosofia enquanto bens culturais, ou seja, a cultura é um vale tudo, tal como na Semiosfera de luri Lotman: um guarda-chuva ao qual tudo se submete, sendo a poíesis totalmente esquecida. Por trás da aparente proteção da cultura, está, na verdade, uma essência de exclusão. As artes estão sendo preteridas. Hoje, o que mais se vê é a cultura restrita à indústria da cultura. Por consequência, não se entende mais a diferença daquilo que é moral, datado e condenado à obsolescência, tal como nos fenômenos da cultura, daquilo que é uma singularidade artística, transcendente de seu tempo (do latim, transcendo). E se tudo é relativo, logo, tudo é tudo e nada é nada. Nós, os artistas da poíesis, em nosso lugar de fala - se é que aqui posso usar tal expressão tão disseminada pelos estudos culturais - na condição de autor, em sua liberdade inventiva, sentimos na pele o esquecimento da poíesis. Não está bem resolvida a questão coeva, em que a elaboração da obra de linguagem não é mais levada em consideração. Aliás, o culturalismo peca duplamente: ignora a questão da linguagem na arte e não reconhece a deturpação ideológica na indústria da cultura. 
Isso é verdade. Não está bem resolvida. É um outro debate muito importante. Mesmo a relação entre Linguística e Literatura, na nossa área, é tensa. Há problemas. Poderíamos chamar, por exemplo, um Antropólogo para falar dos estudos culturais, de outra perspectiva. É uma questão muito relevante.

\section{8)Prof. Dr. Rubens Russomanno Ricciardi (FFLCRP)}

Quanto ao trabalho de tradução, nós tivemos, recentemente, uma publicação conjunta com a Profa. Dorothea Hofmann. Traduzimos um requerimento de Bach, em que o compositor solicita ao Conselho da cidade de Leipzig, bolsas para seus alunos músicos. Demoramos 15 dias para traduzir o texto. Ela, alemã; eu, brasileiro. Apesar de ela saber bastante o português, e eu ter morado alguns anos na Alemanha, há dificuldade em relação ao vocabulário do século XVIII de Bach, em um contexto musical. Nós não nos preocupamos em publicar em revista indexada e externa. Publicamos na Revista da Tulha mesmo, do Departamento de Música, atrelada ao NAP-CIPEM, porque quero que os nossos alunos leiam. Nós não estamos mais preocupados em procurar aquela revista que tem um Qualis diferenciado. Se formos atrás disso, não trabalhamos mais. É importante que os alunos leiam, que o texto esteja disponivel. Nessa pesquisa, revelou-se um Bach extremamente crítico e preocupado o tempo inteiro com a qualidade artística. Não há nenhuma frase religiosa em Bach, nem referência a Deus, em nenhum momento de seu documento. Aliás, Bach sempre está priorizando a música experimental moderna, a inovação do gosto. Ele exige um esforço maior de relacionar os diversos estilos poéticos da época (além dos alemães, também italianos e franceses) com as exigências da práxis musical. $\bigcirc$ artista moderno tem que ser dinâmico. Bach solicitava sempre maiores verbas para que seus alunos obtivessem o regozijo da bolsa para uma performance artística mais digna. Na tradução, é necessário ter todo um domínio contextual, e esse tipo de publicação sequer é devidamente valorizado. 
Na sequência, passo a fala ao Prof. Marcelo Papoti, da área de Educação Física, Vice-Diretor da Escola de Educação Física e Esporte de Ribeirão Preto. Inclusive, estávamos falando sobre como a Educação Física e a Música, especificamente, são bons caminhos para a formação de nossas crianças. Nós temos a vocação natural de formar (de Bildung) nossas crianças, mais do que outras áreas do conhecimento. Por exemplo, não se pode ensinar a filosofia de Wittgenstein a crianças de 8 anos. Mas elas podem aprender a tocar um concerto de Mozart brilhantemente. Nós temos que valorizar a Educação Física, o Esporte e a Música, como um caminho de educação. Por isso, buscamos uma parceria forte para integrar ações realmente de intervenção, a fim de trabalhar com comunidades vulneráveis e trazer esses talentos para a Universidade desde cedo.

\section{9)Prof. Dr. Marcelo Papoti (EEFERP)}

Costaria de estimular uma reflexão sobre as angústias que a Educação Física, sendo uma área aplicada, tem passado no sentido de falta de valorização e de como a produção do nosso conhecimento tem sido dividida ou desvalorizada nas métricas comumente utilizadas. Resgatando alguns termos que foram utilizados nas discussões passadas, conforme apresentado no Manifesto de Leiden, que é o documento utilizado como base para esses seminários, as avaliações das pesquisas e dos pesquisadores têm sido realizadas, principalmente, com base em dados, ao invés de juízo de valores. Temos observado um aumento no número das métricas que são utilizadas para a realização dessas tais avaliações, que, embora bem intencionadas, nem sempre são bem aplicadas. Manifesto ainda acrescenta 0 fato de que corremos o risco de termos a produção do conhecimento prejudicada pelas próprias métricas que foram desenvolvidas para potencializá-la.

De certo modo, esse possivel ou latente prejuízo na produção do conhecimento científico obedece à observação do cientista social, Donald Campbell, cuja formulação ficou conhecida como a "Lei de Campbell". De modo geral, ela diz que quanto mais o indicador social quantitativo for usado em processos sociais de tomada de decisão, maiores são as possibilidades de distorções dos processos sociais que se pretende monitorar. Aplicando a "Lei de Campbell" ao uso indiscriminado 
das nossas métricas é possivel dizer que, quando a métrica passa a ser a meta, deixa de ser uma boa métrica.

A Educação Física, que atualmente está classificada na área 21 da CAPES, juntamente com a Fisioterapia, a Fonoaudiologia e a Terapia Ocupacional, é um exemplo interessante de como as métricas podem influenciar a produção de conhecimento e, consequentemente, o comportamento dos pesquisadores da própria área.

Especificamente em relação à Educação Física, enquanto prática social e disciplina acadêmica, ela tem uma longa e fundamentada tradição de aplicação prática, principalmente de intervenção social. É interessante notar que, na década de 60, Bryant Conant, um Reitor de Harvard, questionou a presença de Educação Física nas Universidades, exatamente porque, para ele, ela não possui um objeto próprio de estudo. Ou seja, foi alegado que a Educação Física não tinha o que pesquisar e, portanto, ela não deveria permanecer nas universidades. A partir desse episódio, foi desencadeado um movimento de valorização acadêmica, que teve como resultado o aumento substancial no conhecimento produzido pelos profissionais de Educação Física. Mas o questionamento que ele fez não foi, na realidade, da competência dos profissionais de Educação Física em fazer pesquisa cientíica, mas da identificação acadêmica enquanto área. Ele alegou que o conhecimento produzido não se caracterizava por ser próprio da Educação Física, podendo, portanto, ser desenvolvido por outras áreas, como a própria Medicina.

No que se refere à Educação Física no campo de pesquisa e produção de conhecimento, observa-se uma heterogeneidade epistemológica com objetivos e conteúdos que transitam por diversas áreas. Com o objetivo de ser uma disciplina reconhecida, legítima, valorizada e com grau acadêmico, a Educação Física vinculou-se nas denominadas áreas mãe, a fim de se fundamentar seu conhecimento. Até pouco tempo, no início dos anos 2000, grande parte do corpo docente na Pós-Graduação em Educação Física era predominantemente exógena, ou seja, composta por Doutores formados fora do sistema de Pós-Graduação na área, o que, talvez, ajude a explicar essa enorme falta de identidade epistemológica. Ao mesmo tempo em que reconhecemos a necessidade de uma produção específica, grande parte do conhecimento é direcionada para as áreas mãe, que tradicionalmente 
são mais valorizadas e atendem melhor às métricas comumente utilizadas nas avaliações dos programas de Pós-Graduação.

De modo geral, as pesquisas em Educação Física estão divididas em três categorias: Biodinâmica (pesquisas atreladas à matriz biológica, como Biomecânica, Fisiologia do Exercício, Aprendizagem e Controle Motor), área sociocultural (as pesquisas investigam temas como esporte e as práticas corporais na Sociologia, Antropologia, História e Filosofia) e a terceira, que é a área Pedagógica (as pesquisas tratam aspectos metodológicos, sociais, políticos e filosóficos ligados à Educação Física escolar, formação de professores e também da pedagogia do esporte).

Recentemente, foi publicado um trabalho que analisou a produção científica das teses de Doutorado entre 2001 e 2010. Demonstrouse que os programas, naquela ocasião, que foram avaliados com os maiores conceitos pela CAPES (6 e 7), na época, os programas da UNESP e da USP de São Paulo, respectivamente, apresentavam o dado de que $90 \%$ de toda a sua produção científica estavam concentrados na área de Biodinâmica. Ou seja, há um forte cunho biológico. De maneira concomitante, nós temos observado, na nossa área, uma fuga de pesquisadores ligados às áreas socioculturais e pedagógicas da Educação Física para outros campos, cuja política de produção científica apresenta-se mais adequada do que o tipo de pesquisa característica das ciências humanas e sociais, como a Educação, a História, as Ciências Sociais. $\bigcirc$ Prof. Eduardo Kokubun, um professor que tem investigado a produção e a distribuição de conhecimento científico em Educação Física, relata que, às vezes, a pesquisa que fazemos em Educação Física e Ciências do Esporte ou a forma como a dividimos, que se reflete nas concepções da Pós-Graduação, ainda não tem saído da década de 60 . $\bigcirc$ mesmo professor ainda relata que, se for decidido que, para permanecer nas universidades, a Educação Física, assim como outras áreas aplicadas, devem fazer pesquisa básica, ela corre o risco de acabar. Em concordância, o Prof. Co Tani, estudioso da área da nossa coirmã, da Educação Física de São Paulo, coloca que os conhecimentos básicos que foram produzidos pelas subáreas da Educação Física não promoveram nenhuma mudança no modo de atuação prática dos profissionais, que, teoricamente, seriam os consumidores desse conhecimento.

Embora reconheçamos a necessidade e relevância da inter e multidisciplinaridade, resistimos às interferências que outras áreas 
exercem sobre o modo como o conhecimento da Educação Física é produzido e tem sido valorizado. $\bigcirc$ que o caracteriza, portanto, é um contexto bastante paradoxal.

Ironicamente, podemos assumir que a pesquisa relevante ainda é somente aquela realizada dentro dos preceitos do rigor científico. Pesquisa de boa qualidade sempre é aquela mais bem resolvida teoricamente e metodologicamente. Parece ser mais importante o impacto do Journal Citation que o impacto social. No entanto, o Manifesto de Leiden traz que a pesquisa que avança as fronteiras do conhecimento acadêmico difere da pesquisa que é focada em solucionar os problemas da sociedade.

fato é que o cenário atual, não somente na Educação Física, mas em áreas aplicadas, apresenta-nos uma fragmentação extrema, em que há subáreas diversas que pouco interagem. Conforme relatado anteriormente, resulta-se, cada vez mais, na migração de pesquisadores da área sociocultural e pedagógica para outros campos do conhecimento. Logo, embora existam pesquisadores que defendem identidade epistemológica da Educação Física e outros que são totalmente contra, inclusive de sua própria existência, se admitirmos essa segunda premissa, perdemos totalmente o sentido de aglutinação por área. Não precisaria existir a área em que se encontra a Educação Física, por exemplo. Além disso, é importante destacar que, em função das características da Educação Física, temos um enorme desafio de diminuir a distância entre os avanços da produção científica e o que é empregado pelos profissionais que atuam nas escolas, academias, nos clubes e no campo esportivo.

A propósito, o campo esportivo ainda é um campo mal resolvido nacionalmente, porque, em países mais desenvolvidos, a aproximação entre o esporte e o exercício, provenientes do campo prático, com a Universidade é um processo absolutamente natural. Isso é importante porque o campo de atuação, na realidade, é o que gera conhecimento, e os questionamentos devem retroalimentar o sistema. Há um grupo de pesquisadores da UNICAMP, em Ciências do Esporte, que faz exatamente isso. Coordenado pelo Prof. Claudio Gobatto, eles buscam os problemas práticos e, muitas vezes, simulam esses desenhos experimentais em modelo animal para dar um retorno aos problemas aplicados. Trata-se de um exemplo de interação que é possível ser feito entre as áreas. 
conhecimento produzido por esses profissionais que estão atuando na prática, embora não contemplem, em sua totalidade, as premissas do método científico, devem ser especialmente valorizados pela Educação Física, especialmente pela área 21 . Embora o termo não seja classificação ou adequação da área nas métricas, essa divisão, obviamente, envolve as possiveis classificações.

As métricas relacionadas à valorização do conhecimento produzido nas áreas aplicadas, assim como em outras, na verdade, são estabelecidas pela própria área. Então, se existe um problema, é nossa responsabilidade resolvê-lo, afinal, somos nós que fazemos o Qualis e as métricas. Gostaria de citar um exemplo da Universidade de São Paulo em que, recentemente, tivemos a oportunidade de elaborar um plano de desenvolvimento acadêmico da Unidade. Nesse plano, foi permitido que a própria Unidade apresentasse critérios e o modo como queremos ser avaliados.

Esse tipo de movimento também deve ser estimulado dentro das áreas de conhecimento, para que, depois, a área em conjunto debata o que, de fato, é importante na produção do conhecimento, especialmente, o que deve ser valorizado no âmbito da Pós-Graduação, uma vez que, na Educação Física, a maior parte do conhecimento científico é produzida na Pós-Graduação. Considerando, logo, que a intervenção dos profissionais das áreas aplicadas é um fenômeno complexo e que, portanto, também necessita de um método complexo de investigação, propõe-se o estabelecimento de políticas acadêmicas que também valorizem e incentivem a sistematização e a produção de conhecimento, provenientes da prática profissional, que possam, eventualmente, resolver problemas aplicados. Como exemplo, cito a necessidade de mais estudo e atenção da comunidade científica para os relatos de experiência. A área como um todo deveria investir mais em proporcionar mecanismos de valorização das experiências trazidas pelos profissionais. Assim, nós conseguimos uma boa retroalimentação do sistema, a fim de produzir, de fato, conhecimento científico significativo para determinada área. Talvez seja esse o grande desafio dos programas de Pós-Graduação, especialmente no tocante à produção de conhecimento das chamadas áreas aplicadas, como é o caso da Educação Física. 


\section{0)Prof. Dr. Rubens Russomanno Ricciardi (FFCLRP)}

Vemos que o problema não é somente das artes ou somente de alguns campos. É um problema geral da Universidade. Essas contribuições são importantes para o desenvolvimento de uma crítica, a partir do Manifesto de Leiden.

Precisamos pensar sobre essa nova proposta de missão departamental, sendo já uma mudança de perspectiva importante. Com essa missão elaborada pelas bases, a avaliação institucional terá uma melhora qualitativa. E não podemos ficar reféns dos encargos da CAPES, que acabam prejudicando até o ensino de Graduação. Temos que diferenciar rigidez de rigor. Nós temos que buscar o rigor, e não a rigidez. Aliás, a CAPES peca por isso. Ao contrário do que impõe a CAPES, a filosofia, as artes e as ciências devem ser rigorosas, mas não rígidas.

8 1)Prof. Dr. Eliseu Martins (FEA, FEARP)

Prof. Marcelo Papoti falou sobre a classificação de sua área. Sabe onde está a minha? Contabilidade é Turismo. Em 1977, o Chefe de Departamento e eu, que era Coordenador do Mestrado, viemos conversar com o Pró-Reitor de Pós-Graduação para trazer o projeto para criação do Doutoramento. A resposta dele foi: "e tem o que pesquisar? Já está tudo feito, não tem mais o que fazer". Não quis saber. "O que nós vamos fazer?". $\bigcirc$ Prof. Sergio disse: "vamos pegar o currículo dele (naquele tempo não tinha internet, então demorou meses, mandava correspondencia para a Universidade onde ele tinha estudado para perguntar se tinha PhD em Contabilidade, se tivesse, que mandasse a programação etc.). Nós vamos conversar com ele, mostrar que, na Universidade em que ele fez o PhD, existe PhD em Contabilidade". A situação, então, mudou.

A Contabilidade está fora de metrificação. Partindo do pressuposto de que ninguém é exatamente do ramo, a Contabilidade tem, às vezes, uma característica da aparência de ser parte das ciências exatas: é feito um balanço no jornal, o ativo bate com passivo 
até o último centavo, é uma ciência exata, não tem por onde, mas é a maior enganação do mundo. Na verdade, existe um conjunto de bens e direitos, juntam-se obrigações e definições. Patrimônio líquido é a diferença entre um e outro, pode deixar de bater? Se coloco bens e direitos e coloco as obrigações e a diferença, é óbvio; então é impossivel. Parece que estamos tendo muito disso: a aparência de exatidão na metrificação e toda a avaliação baseada em números realmente dá essa característica de aparentar ser científica, ser exata e ser, talvez, mais objetiva, menos subjetividade envolvida, o que não é, absolutamente, verdade.

Na área de Contabilidade, normalmente o que acontece é isso: só quem entra no ramo descobre que, de objetividade, tem muito pouco. É extremamente caracterizada por subjetividade, por conceitos, por definições, por expectativas. Vamos brincar com o seguinte exemplo: vamos contratar uma construtora para um prédio de apartamentos. Ela vende os apartamentos na planta. Ela terá as suas receitas, terá as suas despesas com a construção e apurará os seus lucros. Ela deve apurar esse lucro quando? De que maneira? À medida que ela for executando, utiliza-se de algum critério de performance para ir se apropriando desse resultado ao longo da construção? Ou devemos deixar pensar o seguinte: como tudo é sujeito a risco, vamos esperar para terminar? Quando terminar, vemos se, afinal de contas, ela teve ou não teve lucro? $\bigcirc$ que acontece? Do ponto de vista tributário, interessaria para a empresa deixar para o fim, porque pagará o imposto sobre o lucro mais à frente. Mas se houver investidores, houver financiadores interessados em acompanhar o desempenho, preferem ir acompanhando se já está tendo mais riscos, porque terão que trabalhar com certo drivers, certos critérios para ir apurando. O custo se sabe, mas qual é a parte da receita que cabe a esse pedaço? Que critério deve ser utilizado para medir o desempenho da construção durante o seu processo? Isso envolve um monte de subjetividade e escolhas, às vezes, um pouco arbitrárias. Um comerciante que compra uma mercadoria, transporta-a, estoca-a, faz belas vitrines, então ele faz todo seu processo de negociação e ainda vende à prestação. Receberá esse dinheiro lá na frente. Como é que nós vamos mensurar o desempenho desse comerciante, se ele recebe o dinheiro no fim, no momento em que ele consegue fazer a venda? Ou já deveria ficar verificando? $\bigcirc$ lucro é um processo: saber comprar uma mercadoria já é parte do lucro, saber expor a mercadoria também é parte do lucro, treinar pessoas é parte do lucro. Mas eu tenho que trabalhar com uma metodologia que seja pragmática. Quando é que

\section{3}

REV. TULHA, RIBEIRÃO PRETO, v. 7, n. I pp. 236-392, jan.-jun. 2021 
vou reconhecer esse lucro? Então, qualquer coisa antes da venda é um negócio arriscado, porque posso não vender. Então vejam, como entra um aspecto de comportamento pessoal, de precaução, por melhor que seja a mercadoria que ele comprou, por mais mercado que tenha, por mais que estejam as pessoas querendo comprar, ele diz: "posso pagar aquele preço?" Será que não é o caso de reconhecer somente no ato da venda? Vendeu, mas não recebeu. Será que faz sentido reconhecer um lucro por performance, pois ainda não viu a cor do dinheiro?

Eu poderia citar aqui vários exemplos, como é o caso de uma mineradora de ouro. Ela está produzindo ouro e, de repente, está com seus lingotes com ouro já purificado, lingotado. Assim, coloca no cofre e vende quando achar que o preço está bom. $\bigcirc$ desempenho deve ser em função da venda? A função vender para o comerciante é extremamente complicada, dificil e relevante. Para a mineradora, o processo de vender ouro é um negócio relevante? Ele paga o telefone, liga para a corretora e diz: "estou vendendo um tanto de ouro". O preço é conhecido no mercado, olha na telinha, está resolvido. Mede-se o desempenho em função do processo de vender. A responsabilidade ou a dificuldade dele é conseguir produzir, e assim vai.

Vemos, com frequência, brigas tributárias, de empresas com - Coverno, e a insegurança jurídica. A empresa está fazendo o reconhecimento de impostos dentro de critérios, que ela interpreta daquele jeito. Vem a fiscalização e diz que não. Reporto no meu balanço que estou sendo cobrado pelo Governo (tem que dar satisfação). Mas eu vou reconhecer que devo, mas não reconheço. Então, critérios de avaliação de uma porção de coisas do balanço estão sujeitas à expectativa de geração de fluxo de caixa, que chamamos, tecnicamente, fluxo de caixa descontado. Se há todo um problema, tem que conhecer de economia como um todo, economia setorial, desempenho da sua empresa para fazer cálculo de certas expectativas, as faixas mais prováveis de geração de fluxo de caixa futuro, depois trazer isso em moeda de agora, quais são as taxas de desconto que devo utilizar, quais são os riscos dos que estão envolvidos nesse processo - porque altos riscos implicam uma taxa de desconto alta, que diminuirá o valor presente desses fluxos.

A Contabilidade tem uma aparência de Ciências Exatas. Às vezes, costumamos dizer, no máximo de exatas, pois pode ter a data. Pessoal dizia antigamente: o caixa é certo. Isso porque não viveu no 
tempo da Panair. A Panair quebrou mesmo com caixa, tendo no balanço um "dinheirão". Como quebra e tem esse dinheirão? Havia auditoria, e a auditoria dizia: "eu contei o caixa". Depois descobriram, os auditores iam lá em Manaus, os caixas ficavam distribuidos nas lojas, os bancos não tinham a facilidade de hoje, contavam todo dinheiro que tinha em Manaus, aí iam para Belém, os auditores iam de passageiro e o dinheiro ia na bagagem. Era o mesmo dinheiro contado $n$ vezes. Ou seja, não dava para dizer que o caixa estava certo.

Ademais, a Contabilidade é um instrumento de gestão, de controle, de processo de decisão. Os critérios que serão utilizados para medir, desse jeito ou daquele jeito, são problemas de responsabilidade da gestão. Acontece que, no caso das empresas (estou falando de Contabilidade empresarial), uma grande parte da utilidade das demonstrações contábeis é para os chamados usuários externos: são os sócios, quando eles não participam de dentro da administração, principalmente quando existem essas sociedades chamadas abertas, que têm acionistas distribuidos em dezenas, milhares, milhões de acionistas, que têm interesse em conhecer o desempenho da entidade, os financiadores, os bancos e os debenturistas. Também, consideram-se os fornecedores de bens e serviços que têm interesse em saber se o cliente vai bem ou vai mal. Também, interessa saber sobre os empregados, o sindicato dos empregados, que, em suas discussões, apresenta as suas pretensões. Obviamente, precisa saber sobre o Governo, principalmente na parte da tributação. Se nós tivermos diversas empresas do mesmo segmento, cada um achando que um critério é melhor que outro, não dará certo.

Existe, portanto, um processo obrigatório de uma normatização. É preciso que se criem normas para que empresas do mesmo segmento façam os seus balanços, as suas apurações de resultados dentro de critérios. Além disso, há problema se o critério no Brasil é um, na Argentina é outro, em Moçambique, nos Estados Unidos etc. Há um risco sério desse processo de globalização, por se analisar desempenho de maneira errada. É um processo de normatização forte em Contabilidade, pois existe um organismo internacional. Há uma competição, os americanos de um lado e o resto do mundo de outro.

que isso tem a ver com processo? Temos, dentro do estudo de Contabilidade, um processo: primeiro de desenvolvimento de conceito, de experiências com critérios que podem ser melhores ou piores, de 
simulações de desenvolvimento de teorias, o que é realmente um ativo. Você tem um automóvel, o que é o ativo? $\bigcirc$ automóvel é o bem em si, ou o que é importante é o que ele produz de utilidades? Quando se fala em uma máquina, fica mais claro: a máquina em si não é o que interessa, o que interessa é a sua capacidade de produzir, a expectativa do que ela é capaz de gerar. Afinal, é importante saber qual dinheiro ela produz para entrar e o que ela gastará para essa produção.

que acaba acontecendo é que temos, na Contabilidade, um mundo conceitual, teórico, que tem que ser bem analisado. Precisa-se produzir ideias para serem testadas, para serem simuladas, para depois passarem ao processo de prática, a um processo de normatização e, no final, serem aplicadas. Qualquer um que é da área, quando pega um balanço do Banco do Brasil, Petrobrás, rapidamente detecta e avalia - desempenho da empresa, porque ela sabe quais são os critérios subjacentes àquelas demonstrações, qual base, quais seus riscos. $\bigcirc$ balanço de uma seguradora tem um nível de risco, o balanço de um botequim, que compra e vende tudo à vista, tem outro. $\bigcirc$ balanço de um banco, com seus recebíveis, com seus riscos de inadimplências e outros tipos de riscos, tem outro. Nós temos, portanto, um processo de desenvolvimento dessa parte teórica.

que acontecia? Na Contabilidade, mais ou menos até 1970, o grosso do trabalho da academia, fora a parte de docência, era ajudar no processo de desenvolvimento de conceitos, de critérios, de levar para o mundo prático, submeter ao pessoal prático (a Contabilidade também tem um outro problema muito sério, às vezes, certas coisas são ótimas, mas são muito sofisticadas e caras, então a relação custo/ benefício é uma espada em cima da cabeça de todos nós). A academia, assim, viveu muito tempo, exclusivamente, nesse processo de normativismo, de criar ideias, discussões, brigas, teses, defesas, polêmicas etc., o que foi um erro. $\bigcirc$ que acabou acontecendo? Veio, muito fortemente, da área da Economia, a tal da pesquisa empírica. Vamos começar a fazer pesquisas empíricas, que, na Contabilidade, são mais fáceis de serem feitas da seguinte maneira: vamos analisar um monte de empresa, 500 empresas abertas, vamos ver os 500 balanços e fazer uma análise de correlação, de período da empresa com esse fator, com aquela norma contábil, com o nível de governança corporativa, com o do auditor que ela tem. Esses dados são públicos, é um banco de dados relativamente fácil. Moral da história, a pesquisa na Contabilidade, em poucos anos, passou a ser direcionada totalmente para a pesquisa 
empírica, na base das correlações, às vezes até sem muito cuidado na relação causa e efeito, o que é um problema sério na estatística. Esse fenômeno foi acontecendo, além do mais, com estímulo nas avaliações de Pós-Graduação, da CAPES etc., na parte quantitativa, na própria Universidade. Moral da história, foi desaparecendo toda pesquisa e todo pesquisador que pensava, que criava etc. Na FEA, encontram-se, talvez, a cada 200 teses, duas teóricas, porque é muito mais rápido. Quanto tempo leva para produzir um trabalho criativo? Quanto tempo leva para fazer um trabalho empírico? Durante um ano, ele faz três trabalhos empíricos: ele leva dois anos, três anos para desenvolver um pensamento conceitual já bem sustentável.

Por consequência, foi desaparecendo a criatividade na academia. Isso foi mudando o próprio perfil do corpo docente, porque começam a conseguir os que produzem bastante estatisticamente, que têm ascensão. Os outros, mesmo quando produzem, não conseguem publicar, porque os avaliadores trabalham isso no Qualis do mesmo jeito. "Ah, se não tiver estatística, se não tiver empiria envolvida, estamos fora; obrigado, não vou avaliar, não quero saber". Às vezes, existe até medo, porque não está nem preparado para avaliar se for um trabalho totalmente conceitual.

Há um caso que ficou famoso de um rapaz que conseguiu, depois de muito tempo, defender uma tese excelente em teoria. Houve um concurso para docência e ele prestou. Ficou famoso porque a banca espalhou para todo mundo que a aula dele foi a melhor já dada. Além disso, o trabalho que ele tinha apresentado como parte, fundamentado na tese, foi o melhor. Mas ele perdeu porque o outro candidato tinha três vezes mais publicações do que ele, e o departamento estava interessado em competir. Isso é um problema tradicional de sempre.

Na minha opinião, isso traz uma deformação no comportamento do corpo e na seleção, porque só vão entrando pessoas que têm esta linha. Isso vem causando um drama, porque o próprio mercado, os próprios órgãos normatizadores praticantes da Contabilidade e Auditorias procuram conceitos. Eles estão atrás de conceitos, e não acham mais. Recebem um monte de papers, de teses e dissertações que eles não conseguem absolutamente entender do que se trata, nem - título eles conseguem entender, porque os títulos ainda costumam ser exageradamente técnicos: dá impressão que se ganha metade da aprovação naquele título de quatro linhas, é sensacional. 
Eu escrevi um editorial, para a nossa própria revista, dizendo sobre a inversão de papéis. Às vezes, discute-se muito mais teoria, hoje, nos órgãos normatizadores, do que na academia. Isso é impressionante. Eu participo de diversos desses órgãos. Hoje de manhã, tive uma reunião do CPC, que é o Comitê de Pronunciamentos Contábeis, que faz, a cada três meses, uma reunião com a Receita Federal, que quer entender melhor sobre essas regras contábeis novas. Eles leem, estudam, fazem uma lição de casa, é impressionante como eles estudam, têm todo o interesse, tiram as dúvidas, discutem etc. Discutiu-se muito mais teoria contábil hoje de manhã (eles querem saber o porquê, eles não querem saber o que está escrito nas normas). Eles querem discutir conceitos. Ou seja, discutimos mais conceitos fora da academia do que dentro da academia.

A minha fala é um depoimento de como a área de Contabilidade está sofrendo também com esse domínio ou quantificação de publicação. $\bigcirc$ que é realmente importante, do ponto de vista acadêmico, é a produção.

\section{2)Prof. Dr. Rubens Russomanno Ricciardi (FFCLRP)}

Nós até falamos no outro encontro que o problema seria em superestimar a lógica da quantidade estatística em detrimento da singularidade qualitativa. Todo mundo está reclamando, em todas as áreas, de que vivemos em função de métricas não raramente arbitrárias. $\bigcirc$ essencial e o diferencial acabam não tendo como sobreviver.

IEA é uma unidade da Universidade de São Paulo que, desde a sua fundação, prioriza a liberdade do pensamento, a manifestação de ideias e, justamente, a liberdade também de pensar diferente. Pensar diferente é a única liberdade que existe. $\bigcirc$ IEA, por ser justamente uma unidade autônoma, foi fundada para pensar diferente, desenvolver ideias, diferentemente de um Conselho de Departamento, de um CTA, de uma Congregação, em que, há muitos anos, nós temos uma função cartorial. Carimba-se e homologa-se. Se considerar o pensamento de Heráclito, homologar é estar de acordo com o lógos. Porém, nesses espaços, nem sempre isso é o que ocorre. 


\section{3)Prof. Dr. Eduardo Monteiro (ECA)}

Em primeiro lugar, é importante falar um pouco da diversidade da Universidade. Isso que está no próprio conceito de Universidade. Quero falar um pouco da minha perspectiva de artista, no caso, de pianista, e também da questão que foi muito mencionada sobre a produção de conhecimento, das diversidades de produção do conhecimento que se encontra na Universidade.

Existem tanto áreas distintas quanto maneiras distintas de produzir conhecimento. Quando vemos, de uma mesma área, modos completamente diferentes sobre a questão da produção de artigos em revistas indexadas (o que acontece na área de música), não significa que é a única maneira de produzir conhecimento.

Como o Prof. Rubens já mencionou, o produto artístico em si é tão fundamental (ou mais fundamental) para o artista do que um artigo. Isso depende da perspectiva de cada professor, de cada pesquisador. Isso é importante que seja valorizado e reconhecido como tal. Em relação a isso, eu gosto muito de citar uma fala de um amigo meu, coordenador da Pós-Graduação em Música na UFRJ. Durante uma reunião em que se discutia sobre as várias perspectivas de apresentar trabalhos, cada área expressava os seus modos: a Arquitetura faz assim, a Engenharia está fazendo assim, a Odontologia está fazendo assim etc. Então por que não falamos o que queremos fazer? Por que temos que sempre se referenciar a outro campo do saber para validar o que fazemos?

Em relação a isso, me chama muita atenção o fato de que o esquema que temos no Brasil, até onde é de meu conhecimento, não existe em nenhum outro lugar do mundo. Eu não conheço todas as Universidades do mundo, mas meus colegas que são professores de instrumento, ou seja, de uma disciplina basicamente prática, que são artistas que produzem, não são cobrados para produzir artigos científicos em revistas. Isso não existe. Naturalmente, não significa que as pessoas não possam fazer isso. É importante pensar, obviamente, sobre como é que o artista faz um concerto, uma composição, uma peça de teatro, enfim, como é que, de certa forma, dissemina-se esse conhecimento. Nesse sentido, um texto mais teórico, mais escrito, faria até sentido. Não necessariamente a teorização, por meio de um artigo, de uma produção escrita, seja a melhor forma de acontecer. Muitas vezes, 
é bastante difícil colocar em palavras aquilo que se faz. É importante considerar a riqueza dentro da Universidade, isto é, entender que todas essas produções são altamente necessárias e importantes.

\section{4) Prof. Dr. Tito Bonagamba (IFSC)}

Eu tive uma experiência muito importante junto com o Prof. Corbani, quando era Pró-Reitor de Pós-Graduação da Universidade de São Paulo. Nós nos defrontamos exatamente com a questão das normas dos programas de Pós-Graduação, porque lá definimos as regras de credenciamento do orientador daquele programa. Nós nos defrontamos exatamente com essa situação de como nós podemos conduzir um processo pelo qual os próprios programas possam definir as suas métricas. Julgamos importante, mais do que isso, não julgar essas métricas dentro de nossas áreas de atuação. Naquele momento, nós decidimos que deveríamos nos aproximar dos diferentes programas, principalmente fora das nossas áreas.

Sobre essa reflexão de que um acadêmico tem que sair da sua caixa para poder avaliar a produtividade de seu colega, reforço que nós temos que o conhecer antes de interpretar. De fato, a Universidade é múltipla. Quem não conhece a Universidade, na sua grandeza, na sua diversidade, não conseguirá entender sobre a área de atuação do seu colega que está em outra Unidade. De fato, assim como não podemos acreditar em uma pessoa que lê apenas um livro, não podemos acreditar em uma pessoa que conhece somente a sua área. Eu não acredito em uma pessoa que conhece somente seu departamento. Não acredito em pessoas que têm preconceito com outras áreas do conhecimento. Nós vamos conhecer a Universidade e desenvolver essa questão da métrica se todos conhecerem os saberes complementares, ou nem mesmo complementares, porque algumas áreas nem são complementares. Nesses últimos quatro anos, eu visitei a FFLCH, a FEA, a FEARP, a ECA. Também, não saio da EEFERP. Eu entendo quando estão discutindo: eu preciso ser avaliado pela minha competência. $\bigcirc$ fundamento principal é esse: se nós vamos ensinar as outras pessoas a nos avaliar, primeiro vamos conhecê-las. 
Também, existe um parâmetro importante: às vezes, nós nos colocamos como críticos de uma situação que o programa de PósGraduação nos impõe ou que o departamento nos impõe ou que a própria unidade nos impõe, exatamente porque essas pessoas que deveriam ser lideranças amplas não aproveitam a oportunidade de fazer parte de um Conselho de Pós-Graduação, que pensa amplo. Não se aproveita a oportunidade. Nós, Diretores ou ex-Diretores, não aproveitamos a oportunidade de conversar com os Diretores ao lado e conhecer a grandeza da Universidade. Essas pessoas bloqueiam quem está preso dentro do próprio programa, do próprio departamento ou da própria unidade. Adiciono: precisamos conhecer melhor como a FAPESP nos olha, porque ela tem um pensamento certamente próximo de que uma FAPESP não pode ser uma agência de repressão à criatividade em todas as áreas do conhecimento. Quando eu tive a oportunidade de ter um Presidente do CNPa na minha Unidade, também o pensamento estava de acordo com o que se pensam. Ele já falou "olha, lá no Currículo Lattes, você já pode colocar as linhas de reflexão nessa área, quando falamos com a Agência USP de Inovação, ela pensa o global e tenta pôr". Nós temos que sair da caixa, da sala, em que nos escondemos, sair do departamento, porque sabemos que existem pessoas que bloqueiam a diversidade do conhecimento, criticam quando se é um Físico que faz algo um pouquinho diferente daquilo que é bonito, de sair nas revistas mais importantes. Nesse sair da caixa, é possivel conhecer a pluralidade da Universidade. Acredito que isso seja fundamental.

Não estou dizendo que não tenha que escrever um documento que repense essa questão da classificação. Mas nós temos que ter a consciência de que, se não nos conhecermos, esse processo não tem exito. Deveria haver um Congresso entre as Unidades e que todos participassem dele. Quando queremos discutir sobre temas de pluralidade, de conhecimento das outras áreas, poucas pessoas se dedicam a esse tema, porque elas não querem sair da caixa, não querem parar de produzir. Se continuar fazendo assim, eu diria que é um enterro, uma morte da Universidade, porque ela perde o que ela mais tem. 
São palavras muito pertinentes. Diante dessa confusão entre rigor e rigidez, nós estamos todos submetidos a uma lógica da produtividade. Isso está matando a ideia de vida acadêmica, não apenas entre nós, professores, que não temos mais nem o clube dos professores para nos encontrar. Nós não temos espaços físicos, espaços de convivência real. Também, em nossos alunos de Pós-Graduação, vejo, cada vez mais, esse espírito de competição produtivista, engendrado na cabeça deles. Muitas vezes, não vão a palestras, a conferências, a encontros, porque aquilo não vai thes render nada, e é melhor ficar em casa trabalhando num artigo que será publicado numa revista que ninguém lerá, porque está todo mundo fazendo o próprio texto, e não está mais lendo nada dos outros. Isso é um problema.

Outro problema também é a relação com as entidades de fomento, com a CAPES e com o CNPq. Nós estamos submetidos a lógicas muito diversas, muito quantitativas - quantidade o tempo todo. Tenho um colega de uma universidade inglesa que tem um teorema: o objetivo da "democracia universitária" é que o professor passe 100\% de seu tempo escrevendo relatório sobre o que ele faz com o seu tempo. Nós estamos em direção a isso. Há uma grande quantidade de tempo que nós perdemos fazendo relatórios e avaliações. Ademais, um concerto e uma palestra não valem. É complicado. Palestras, muitas vezes, não valem nada, zero, porque serão somente uma linha no Lattes. Não adianta querer mudar isso somente aqui, porque envolvem todas as mudanças possíveis. Por exemplo, na UCL, em Londres, existe um método de avaliação interessante. As aulas são avaliadas pelos alunos. Nós temos problemas com isso. Quanto à produção de conhecimento, de extensão, de comunicação e de intervenção com a sociedade, cada professor escolhe, a cada quatro anos, os quatro pontos mais importantes que ele julga que ele fez em âmbito universitário. Pode ter sido um livro, pode ter sido uma palestra, pode ter sido a organização de um congresso. Ele é avaliado por isso.

Temos que, realmente, repensar isso. Acho que os projetos acadêmicos de cada unidade, de cada departamento, é um início. Em nossos departamentos, da nossa unidade, saiu um belo projeto acadêmico que contemplou toda a diversidade. A avaliação, também, 
é mais um plano quinquenal, é mais isso e menos palestras, concertos, produção de conhecimento, encontros.

\section{6)Prof. Dr. Tito José Bonagamba (IFSC)}

Acho essas questões fundamentais. Sobre ficar dentro da caixa, não se pode aceitar que nós temos que ter uma produtividade de 15, 50 artigos por ano. Eu tenho a convicção de que meu papel acadêmico é fundamental na minha trajetória, por isso eu não vou me preocupar em ser um A ou um B no CNPa por causa disso. $\bigcirc$ que o Prof. Rubens comentou sobre nossa trajetória conjunta ou que, talvez, o Prof. Marcelo tenha dito não faz parte do meu Currículo Lattes, mas faz parte da minha consciência como acadêmico. Ela tem muito mais valor do que os papers que eu publico, no sentido de que ou eu sou um acadêmico e tento conhecer a Universidade ou aqueles papers que publico com qualidade não têm o significado correto. Eu estaria defendendo somente o meu eu, e meu eu não tem valor. $\bigcirc$ que tem valor é onde estou e como estou transformando aquele local.

Quem está credenciado em um programa de Pós-Graduação tem que dizer para a CAPES o que é importante. $O$ Prof. Armando Corbani fez, o Prof. Vahan, quando foi Pró-Reitor, fez, e o Prof. Carlotti está fazendo agora. Não é a CAPES que nos impõe nossa qualidade, somos nós. Acho que é a primeira vez que estamos tendo a oportunidade de dizer para a CAPES: como nós fizemos agora, cada departamento e cada unidade têm que mostrar o que é produtividade de qualidade, desde que a Instituição tenha feito esse papel direitinho. Se nós fizermos isso, essa é a métrica que nós entendemos que promove qualidade universitária e que promove, aí sim, a qualidade individual da pessoa, porque ela está inserida no plano acadêmico da Instituição.

87)Prof. Dr. Eduardo Monteiro (ECA)

grande problema nasce na própria área, falando especificamente na área de Música, quando se vê que professores que

\section{3}


são da área teórica tendem a não reconhecer o trabalho de produção da área prática. $\bigcirc$ grande problema é que a própria área não se define e não tem a generosidade de compreender a diversidade e a importância dela. Por isso, na Universidade, é esperado que o conjunto daquela produção seja relevante para a área e produza avanços, mas não que um indivíduo produza sozinho o avanço. É importante que se entenda a própria área, que as pessoas discutam com visão generosa e que compreendam o trabalho do outro. Afinal, "a CAPES somos nós". Quem estabelece a regra da CAPES somos nós mesmos, são nossos colegas que estão lá. Logo, somos nós. A medida que uma área tem, sem esperar um consenso total, depende da grandeza e da generosidade de entender as diversidades. É importante ter isso como uma maneira de pensar e de atuar. A CAPES já reflete isso. Os problemas que temos relacionados à CAPES, em vários segmentos, não se colocam de forma adequada e de forma realmente plural.

\section{8)Profa. Dra. Myrian Nunomura (EEFERP)}

Nossa área, além de discussões epistemológicas, ainda não tem definido exatamente o objeto de estudo. Quando me transferi para Ribeirão Preto, percebi que havia, entre os colegas, uma orientação para que nós definíssemos nossa linha de pesquisa na área básica, porque isso tinha um potencial de produção maior. Enfim, começando na área acadêmica, eu realmente acreditei que esse era o caminho. Mas logo entendi que, como se disse, é uma área aplicada: tem que ter essa inserção na nossa área, realmente. É difícil fazer esse trabalho. Talvez, algumas opções de alguns colegas sejam, justamente por essa facilidade, um fluxo de produção maior. Mas é interessante que essa conversa chegasse também às diferentes gerações de professores, de pesquisadores, porque, no decorrer das gerações, isso também tem sido mudado. No geral, parece que o que nos orienta na área acadêmica é a pesquisa ou é a Pós-graduação. Fala-se muito em conceito, em produção e acaba-se retirando um pouco, dentro da formação dos nossos alunos, a essência do ensino, a essência da extensão, das atividades, porque parece que tudo tem que convergir para alguma produção, algum produto. Eu sei que é importante, mas também, como levantaram, os produtos são diferenciados. Mesmo eu sendo da área da Educação Física, do Esporte, a minha produção não é artigos somente.

\section{4}

REV. TULHA, RIBEIRÃO PRETO, v. 7, n. I pp. 236-392, jan.-jun. 2021 
Há outros produtos que têm o devido valor. Mas se eu me empenhar neles, provavelmente eu serei penalizado nas métricas que existem.

Foi bastante importante a opinião de vocês, essas angústias que as outras áreas também têm. Eu também, durante quatro anos, estive representando a Unidade na Pós-Graduação. Sempre houve essa angústia das áreas, uma vez que a USP também é de A a Z, como dizia o Prof. Vahan, na época de sua gestão. Até hoje, eu não vi muito avanço na nossa área a respeito de como valorizar as diferentes produções que existem, porque, além de nós, que estamos dentro da nossa própria área, há estudos nas Biológicas, nas Exatas e nas Humanas. Os produtos, também, são bastante diferenciados. Realmente, não vi muito avanço. Espero que, pelo menos dentro da USP, com essa nova forma de avaliação, possa se trazer mais luz.

\section{9)Prof. Dr. Hugo Tourinho Filho (EEFERP)}

Em um determinado momento, eu me voltei para a Profa. Myrian e falei: não somos só nós que temos problemas. Serviu até como uma terapia, porque essas questões me afligem muito hoje. Eu vou começar pelas aflições, com a visão de quem está em uma Unidade que está sendo construída. Ou seja, ainda precisamos construir um programa de PósGraduação. Precisamos achar a identidade do curso de Graduação. Portanto, é uma visão, talvez, que vem de uma Unidade que já tem um programa de Pós-Graduação consolidado, que tem professores que já tem uma trajetória dentro da Instituição de mais de 20 anos. Ou seja, uma Unidade em que o mais velho não tem 10 anos de Instituição, que vive essa realidade de métrica. Eu não vou ficar "cuspindo", porque acho que teve o seu valor, principalmente no desenvolvimento da PósGraduação. Começou com a questão das avaliações dos cursos de Pós-Graduação, com a questão "como nós vamos quantificar?". Surgiram, depois, os Qualis: A, B, C, e assim por diante. Eu vejo a sua importância, mas vejo que estamos, efetivamente, no momento de discutir.

Exemplificando com uma questão prática, num concurso de que eu participei, em uma disciplina da área básica em que o âncora do concurso, o professor que era voltado para aquela área, disse para mim: "eu não posso conceber um professor dar aula dessa disciplina e

\section{5}

REV. TULHA, RIBEIRÃO PRETO, v. 7, n. I pp. 236-392, jan.-jun. 2021 
não ter produção científica". Ele me falou isso. Naquele concurso, havia um candidato que não tinha uma produção científica expressiva, mas era um professor magnífico. Eu fiquei quieto naquele momento, porque eu percebi que havia, inclusive, um certo "radicalismo", porque eu já conhecia o professor, que é um professor com uma expressiva produção científica numa área de uma disciplina "dura", como se diz. No final do concurso, esse professor, que era meu colega de banca, falou assim: "eu nunca assisti a uma aula tão boa sobre esse assunto, que é chato, como esse professor deu". Esse professor foi aprovado, porque esse concurso era para professor substituto. Não se animem, ele foi aprovado porque era para professor substituto. Ele trabalhou nessa disciplina (eu gosto de acompanhar), de modo que uma disciplina que era odiada passou a ser respeitada. Nunca tinha visto. Eu acompanhei porque é uma disciplina de que eu gosto. Depois, fizeram o concurso efetivo. Ele voltou a participar desse concurso com pessoas que tinham uma produção científica expressiva. Ele não passou no concurso, e os velhos problemas voltaram a acontecer. É isso.

Qual é minha preocupação hoje? Não é de um professor que talvez esteja sendo penalizado porque não tem uma produção ou porque não está se adequando a essa métrica. A preocupação é de quem percebe que isso está impactando diretamente na qualidade da formação dos nossos alunos.

Em 95, eu li um editorial de um médico cirurgião, meio profético, dizendo do medo dele de que o conhecimento dele, em operar, talvez perdesse o valor. Mais agora, no século XXl, eu li um artigo que tinha o seguinte título: "Doutorzecos de muro de arrimo", que falava sobre uma revolução nos cursos de Engenharia, que deveriam repensar a contratação de seus profissionais, para atingir a meta de número $x$ de doutores, número $x$ de mestres $e$, por isso, teriam que dispensar os Engenheiros que tinham experiência de fábrica, o "chão de fábrica".

Preocupa-me o seguinte: em várias áreas, não somente na minha, percebemos que os alunos que fizeram uma boa iniciação científica, porque estão vinculados a um bom grupo de pesquisa (eu não tiro o valor disso), não necessariamente possuem uma formação. Preocupa-me a formação, é só ter uma única visão. É um aluno de Graduação em um projeto para falar sobre mercado de trabalho: "mas eu não produzi, não publiquei nenhum artigo ainda”. Não se consegue o sucesso somente por produzir artigos. Há várias maneiras de ter sucesso na sua profissão. 
Não há uma métrica somente, logo, o aluno tem que estar ciente de que o sucesso não está atrelado apenas à produção científica, porque isso está impactando na qualidade da formação dele. Precisamos repensar sobre os professores que nós temos como pares. Eu preciso ter um professor que tenha produção científica, não podemos descartar isso numa Universidade, principalmente na Universidade de São Paulo. Eu não posso descartar, por exemplo, na minha área, aquele professor que tenha experiência frente a equipes esportivas, que saiba fazer 0 link com o mercado, que saiba dar exemplos. Então o "doutorzeco de muro de arrimo" é que tirou o engenheiro com experiência de obra para colocar aquele que tem uma produção científica sobre obras, mas não necessariamente têm experiência com isso. Parece paradoxal: como eu produzo e não tenho experiência? É possível, volto ao meu exemplo, um aluno de IC, de orientador com produção científica consolidada, sair da Graduação, entrar no Mestrado, sair do Mestrado entrar no Doutorado, ter um currículo muito bom, surgir um concurso e, se esse concurso for para uma área aplicada, passar nesse concurso e ensinar aos nossos alunos o que ele nunca trabalhou. Isso acontecerá no Direito, na Medicina, na Educação Física, na Música.

Não é o medo de um professor ser penalizado porque não tem produção científica. É o medo do monstro que nós estamos criando dentro da Universidade. Uma única métrica que está implicando diretamente a qualidade de formação dos nossos alunos é o que me angustia todos os dias.

90) Prof. Dr. Rubens Russomanno Ricciardi (FFCLRP)

$\bigcirc$ Prof. Hugo Tourinho usou uma expressão sobre a qual nós pensamos muito. Além disso, tive o privilégio de ter o apoio do Prof. Aloysio Fagerlande, que é fagotista da UFRJ, na redação do projeto de Mestrado Profissional da Música em Ribeirão Preto. Não usamos a palavra mercado, porque a missão da Universidade é preparar o aluno para o mundo do trabalho, apesar do mercado. Usamos o termo mundo do trabalho, que é mais amplo, aquele no qual o estudante poderá construir o seu futuro com maior liberdade. Em termos de arte, se preparamos o estudante meramente para o mercado, teríamos que propor cursos de DJ e nos restringirmos à indústria da cultura. 
A palavra prática tem o mesmo problema. Temos colegas com 10 ou 15 anos de docência que nunca estiveram em uma empresa. Como é que pode acontecer isso? Concordo com a diversidade de haver um ou dois absolutamente teóricos. Isso é importante, mas o pessoal tem que ter essa prática, sem dúvida. Na Contabilidade, não tem jeito, tem que ir lá ver, não tem jeito.

\section{2)Profa. Dra. Lia Amaral (IF)}

Foi daquele primeiro evento, aqui no IEA, que resultou tudo isso. Esse evento foi feito no IEA justamente pensando na ideia de reformular a maneira de avaliar os docentes e os departamentos. Para mim, foi muito impressionante, porque, durante a vida inteira, eu me dediquei a ser interdisciplinar, atuando na interface Física-Química-Biologia. Volteime, também, em um longo processo de ensino e extensão, à parte de atualização de professores da rede pública, sempre para o geral. Eu só pude fazer isso porque, antes, eu consegui virar a primeira mulher a ser professora titular do Instituto de Física da USP, que era um "clube do Bolinha" e que, digamos, o poder continua sendo um "clube do Bolinha". Só que, depois que eu abri a porteira, entrou um monte de mulheres. Depois que eu consegui "chegar lá", eu consegui, junto com outros, fazer um Departamento de Física Aplicada, que não existia, porque ideologicamente era considerado um absurdo. Era um Departamento de Física Aplicada e minha área é Cristalografia, que alguns físicos acham que não é bem Física, porque é Física, Química e Biologia. É muito interessante o que foi colocado, porque a problemática dentro de uma disciplina é que define toda a problemática do resto. Se for examinar as diferenças dentro da Física, são absurdas: quem faz parte experimental é considerado um lixo e quem faz teoria "que não serve para nada" é considerado um supra sumo. É uma distorção, que, no começo, quando entramos no sistema, somos obrigados a aceitar, porque senão não se progride. Quando eu tomei a decisão de me aposentar para fazer somente o que eu queria, eu continuo até hoje no esquema de professor com direito a continuar, então eu posso fazer o que eu quero, não preciso provar nada para ninguém, mas é muito difícil.

\section{8}

REV. TULHA, RIBEIRÃO PRETO, v. 7, n. I pp. 236-392, jan.-jun. 2021 
título deste estudo, que se refere à "reformulação das divisões do conhecimento”, é muito diferente. De um lado, há a divisão que existe entre áreas do conhecimento, de outro, completamente diferente, são os critérios de avaliação. Tudo que foi tratado é perfeito quanto aos critérios de avaliação, mas isso não entra na questão das grandes áreas do conhecimento. É isso que vocês estão achando que é trivial, a passagem da prática de conseguir avaliar para as grandes áreas do conhecimento. As grandes áreas do conhecimento têm motivo histórico, de séculos, para existir nessa divisão que existe: as Exatas, as Ciências da vida $e$ as Humanidades.

Quer dizer, o fato de existirem essas três linhas, para entender a força dessas três linhas, tem que se voltar para a Grécia. Não é possivel entender a divisão sem voltar para a Grécia e entender como é que cada uma dessas linhas foi. Não adianta imaginar que vão jogar fora tudo. Por exemplo, quanto ao termo Ciências da natureza, é um absurdo querer juntar, em Ciências da natureza, tudo o que é ciência no sentido estrito, porque não é assim. $\bigcirc$ que é Ciências da natureza? $\bigcirc$ ser humano não faz parte da natureza? $\bigcirc$ que é a Matemática? É uma ciência da natureza? Por exemplo, e a Biologia? As Ciências da vida não são redutíveis à Física e nem à Físico-Química. A Biologia Molecular já está praticamente reduzida à Física e à Físico-Química. Nesse caminho, porém, não se consegue entender como funciona a menor célula viva que existe. Para poder ir em direção à vida, deve-se aceitar que a vida existe, embora não se consiga explicar, definir ou compreender.

A única união que houve, de verdade, foi entre a Física e a Química. Isso ocorreu na passagem do século XIX para o século XX, porque a Química se definiu como ciência quando conseguiram fazer a tabela periódica. A Química conseguiu se juntar com a Física. A Física acha que abarcou a Química, mas foi o contrário: a Química abriu caminho para conseguir existir a Física moderna. Os físicos, em geral, não reconhecem isso porque têm a ilusão de que a vida está definida no que eles sabem. E não está. É uma luta insana, com relação aos conceitos, com relação às aplicações e como avaliar tudo isso.

Tudo que foi dito aqui sobre avaliação está perfeito. Mas o problema é o ser humano. É a cabeça dos homens e a cabeça mais genérica das mulheres. Tudo que é entendido como teoria é a maneira como o homem entende, como se organiza, classifica-se, como se faz. Não é errado, mas não se consegue integrar. Logo, o ponto mais

\section{9}

REV. TULHA, RIBEIRÃO PRETO, v. 7, n. 1 pp. 236-392, jan.-jun. 2021 
importante é a questão da interdisciplinaridade, porque, hoje em dia, não dá mais para o conhecimento ficar todo compartimentado. Como é que se toma conta da interdisciplinaridade? Não tem como. Não se consegue definir, não se consegue jogar fora.

problema mais fundamental atrás de tudo é a diferença entre qualidade e quantidade. Por que é feita essa métrica toda? Porque - ser humano quer escapar da questão da qualidade, que não é trivial, que não tem solução. Então vamos tentar chegar a uma solução quantitativa que não existe, porque não se consegue passar da qualidade para a quantidade. Antigamente, existia uma autoridade que definia qualidade. Havia os donos de certas áreas, mesmo em Artes. Eu sou de uma época em que, a respeito de qualquer evento artístico, por exemplo, uma peça de teatro nova, ficavam todos desesperados para saber, no dia seguinte, a opinião do crítico que entendia do assunto. $\bigcirc$ crítico, portanto, definia a qualidade. Acabou isso e acabou a ponto de se destruir a qualidade. Como se diz o que é qualidade e o que não é qualidade?

Costo muito de música, de arte. Meu avô foi pintor, minha mãe foi pintora. Minha mãe sempre conta que, quando eu era pequenininha, ela me levava ao museu e eu falava: "olha lá, Van Gogh". Eu tive essa vivência. Eu segui as bienais, desde que começaram. Chegou uma hora em que eu parei de ir. "Chega, não dá mais, virou qualquer coisa".

$\bigcirc$ problema fundamental é como o ser humano pode tratar a questão da qualidade, porque, na hora em que se massifica, vai embora. Enquanto a qualidade está associada a uma certa autoridade reconhecida, o sistema funciona. Quando massifica e "democratiza para valer", qualquer coisa vale, porque qualquer pessoa tem o direito de fazer.

\section{3) Prof. Dr. Rubens Russomanno Ricciardi (FFCLRP)}

Lembro que o conceito de Ciências Humanas, tal como mencionou - Prof. Alexandre da Silva Costa, em sua palestra, não que seja certo ou errado, apenas que não faz sentido, afinal "toda ciência é humana", como ele disse. E devemos pensar em termos de estudos culturais, e 
não em ciências humanas ou humanidades. Temos sim que nos libertar do nonsense (da falta de sentido) do rótulo "ciência humana". Existe por acaso alguma ciência que não seja humana? $\bigcirc$ que seria uma ciência inumana? Ou haveria uma ciência extraterrestre? Aí sim quem sabe faria sentido, diferenciarmos as ciências humanas das ciências dos ETs, daqueles seres oriundos de outros possiveis planetas. Por enquanto, ainda não dispomos desta alternativa.

Ou ainda, o Holocausto já nos indignou com ciências desumanas e não devemos esquecer os crimes nazifascistas em nome das ciências. Neste sentido poderíamos falar sim, como contraponto à barbárie, em ciências humanas, voltadas para o bem (rompendo as relações entre ciências e perversidade). Só que neste caso seria uma outra acepção de ciências humanas, diversa da discussão aqui. Talvez "ciências para a paz", reunindo todas as formas de conhecimento? Mas quem sabe seja apenas um sonho remoto ainda. Se formos pensar para além da mera cultura, a ciência humana por excelência seria a medicina, porque deve tratar do ser humano em sua plenitude.

Por fim, lembro ainda que a arte tem algo diferente dos estudos culturais. Quando o Prof. Eduardo Monteiro toca um Estudo de Chopin, cada vez que toca, o compositor é revivido. Ele tem uma nova vida, não é uma mera música franco-polaca do século XIX. É uma música que nos diz respeito. Por exemplo, Ernesto Nazaré e todas as nossas valsas caipiras seriam impossiveis sem Chopin. Essa força da arte transcende a cultura. Nós temos justamente a práxis e a poíesis, que não há nos estudos culturais. Quando eu falo da literatura, eu não entendo como um estudo cultural, eu entendo como uma arte. A tradução de um poema é, no caso, uma arte.

\section{4)Profa. Dra. Lia Amaral (IF)}

Ao longo de toda a ldade Média, a Música ia junto com a Matemática justamente porque é universal. Não está do lado da Retórica, que são as coisas do homem. A música estava junto da Matemática. As profissões nem entravam, porque as profissões eram as coisas das pessoas que estavam fora da Universidade. Tem que ter essa visão para conseguir perceber que a música vem antes de tudo. 


\section{Encerramento}

\section{5) Prof. Dr. Rubens Russomanno Ricciardi (FFCLRP)}

Por sorte, há confluência de críticas nas mais diversas as áreas, já que os problemas são semelhantes. Precisamos valorizar a multifariedade do conhecimento e, quem sabe, viabilizar um legado de maior liberdade na pesquisa e no pensamento crítico. $\bigcirc$ desafio é superarmos as métricas arbitrárias, bem como valorizarmos a práxis e a poíesis, nas mais diversas áreas, promovendo, ainda, mais ações extramuros da universidade em benefício das populações de nosso país. Muito obrigado. 